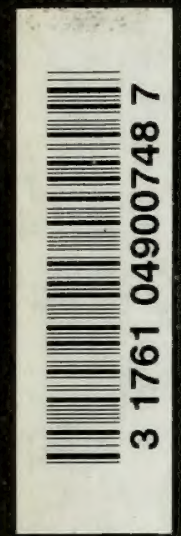

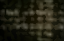

$\frac{2 L}{335}$
335

NIV. OF RONTO BRARY 
Digitized by the Internet Archive in 2008 with funding from Microsoft Corporation 

MEMOIRS

oF

THE WISTAR INSTITUTE OF ANATOMY AND BIOLOGY

No. 3

EARLY STAGES OF VASGULOGENESIS

IN THE CAT (FELIS DOMESTICA)

WITH ESPECIAL REFERENGE TO

THE MESENCHYMAL ORIGIN

OF ENDOTHELIUM

H. VON W. SCHULTE

FROM TBE ANATOMICAL LABORATORY OP COLUMBIA UNIVERSITY

PHILADELPHIA, PA.

1914

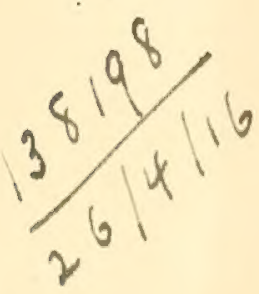




$$
\begin{aligned}
& Q L \\
& 835 \\
& 535
\end{aligned}
$$




\section{VASCULOGENESIS IN THE CAT}

Of the many problems that engage the attention of students of the vascular system, none is more fundamental, and hardly any more perplexing and confused today, than that of the origin of the simple squamous epithelium (endothelium) which is the common lining of all vascular channels, whether haemal or lymphatic. It has been held, and the opinion of late has been zealously propagated, that so far as the vessels of the body are concerned, their endothelium arises solely from the already formed endothelium of the extra-embryonic vessels, or if there is any production of endothelium within the body of the embryo, it is for so brief a period and so inconsiderable in amount as to be theoretically negligible. ${ }^{1}$ For the supporters of this view Rabl's dictum, "Endothel stammt nur von Endothel" is still a satisfactory summary of the facts. A logical sequence of this opinion is the doctrine of the specificity of endothelium, obviously a much broader generalization, which takes endothelium out of the series of mesenchyme derivatives and separates it absolutely from the blood, should that prove to be of mesodermal origin. Consequent thinkers who support this view have seen the importance of assigning an entodermal origin to both blood and endothelium. Could this be established, it would lend a degree of antecedent probability to the doctrine of the angioblast but, strictly speaking, it is not a necessary postulate, for a tissue arising diffusely from the mesenchyme, may as development proceeds, be confined to definite localities or even ultimately be restricted to homoplastic proliferation. Such a tissue would be specific if it yielded no heterogeneous products, and I feel myself that this latter property enters more largely

${ }^{1}$ Minot, Evans, and Sabin in Keibel and Mall, Handbuch d. Entwickelungsgesch. d. Mensehen, Leipzig, 1912. These writers have made a clear and emphatic statement of the doctrines of the Angioblast and of the specificity of endothelium, and presented the evidence which may be adduced in favor of these views very completely. That they have not considered all the available evidence, however, is apparent from their all but complete omission of the results of recent haemotology (since 1909), which would indicate the wisdom of some reserve in accepting as final generalizations which neglect such extensive and important data. 
into our idea of specificity as applied to tissues than the community of origin of their elements. It would seem, therefore, that the advocates of specificity have charged themselves rather to prove that endothelium, once formed, produces only endothelium and never any other elements, as say blood or connective tissue, than that it is peculiar in its origin.

On the other hand, it has been held that endothelium is simply a derivative of the mesenchyme from which it arises diffusely by a multitude of separate anlages. This view does not undertake a general interpretation of the mesoderm and mesenchyme and the apparent variations of their mode of origin as determined by the yolk-content of the ovum, but merely states that endothelium arises out of elements which have once formed a part of the general mesenchyme complex. A development of this point of view is the adaptive theory of endothelium, which holds that endothelium is a modification of mesenchyme, and by no means a stable one at that, but owes its presence to hydrodynamic forces, and when these cease to operate, endothelium disappears as endothelium and reverts to mesenchyme, or gives rise to products indistinguishable from those of mesenchyme. Endothelium is taken to be a form which mesenchyme assumes in certain positions which can not be retained with the loss of position and is then analogous to the biaiometamorphoses of plants grown under unnatural conditions, which are lost when they are returned to their normal environment.

It is conceivable that some supporters of the adaptive theory of the origin of endothelium may not feel themselves obliged to maintain a variety of products on the part of endothelium, just as it is not to be required of those who hold the specific doctrine that they should demonstrate an entodermal origin. The former might then hold endothelium to be a derivative rather than a modification of mesenchyme; it would satisfy them to show the multitude of its separate anlages, their wide diffusion through the mesenchyme, in the somatopleure as well as in the splanchnopleure, within the body of the embryo as well as in the yolk-sac, and their continued formation in the embryo during an appreciable period of development, and along the major 
vascular lines. This done, they could allow endothelium to manifest such specificity as it might acquire, as in the case of other mesenchymal derivatives, eartilage for example, or crossstriated muscle, which increase by accretion of new elements as well as by the proliferation of those already formed, and yet once formed, are specific to the degree that they probabably do not give rise to other types of connective tissue.

In thus comparing the angioblastic with the mesenchymal, the specific with the adaptive views of endothelium, I have alluded to certain differences of opinion regarding the supposed mode of its wide dissemination through the connective tissue of the body, which are fundamental and may now be contrasted. The doctrine of specificity holds this process to be essentially one of growth. The period of development of endothelium is amazingly short, and the site, for most entertainers of this view, is the yolk-sac at some distance from the embryo. For others there is an abstract possibility that certain parts of certain embryonic vessels may develop in situ, but it is not unfair to say that they consistently tend to minimize and curtail the developmental period of endothelium. The important part of their doctrine, the part which has engaged their chief attention, and is presented with most conviction, is the growth of the endothelium by solid sprouts from the ends of hollow injectible vessels. This is the sole source of endothelium (the case of a few embryonic vessels apart), and so far as I am aware, absolutely the only evidence of its specificity.

The adaptive theory finds support in the presence, through a considerable period of ontogeny, of numerous separate sacs or vesicles of endothelium, definitely localized in positions subsequently occupied by continuous vessels, and in the gradual enlargement and ultimate fusion of these vesicles to form the vessels. Further, it notes that the vesicles are preceded by minute clefts or spaces in the mesenchyme bounded by ordinary mesenchyme cells, which subsequently flatten and eventually form a continuous layer as the vesicles enlarge. This view thus extends the period of development, and enlarges the area in which it is active to practically the whole body of the embryo. It does not 
deny that endothelial cells undergo mitosis, that vessels after formation lengthen, or that they may branch and send out sprouts; for it by no, means implies that endothelium does not grow, but it relegates these phenomena to a later period in the life of the embryo, and endeavors to distinguish between a cytomorphosis terminating in a definable type of cell (development, genesis, anlage, das Werden) and a proliferation and extension of a fully formed tissue (growth, das Wachsen).

One further point, the great vascularity of the embryo as compared with the adult makes the fate of the temporary vessels and their endothelium of some importance to a general theory of this tissue. The adaptive view considers that they revert to mesenchyme, the doctrine of specificity that they disappear.

Divergent principles of interpretation rather than differences in method and technique underlie, I believe, these discrepant theories, although I am aware that the contrary has been emphatically proclaimed, and in particular that the method of injection has been held to be the ultimate criterion in these matters. Without discussion at this point of what I believe to be the claims of enthusiasm, it is still possible to admit the objective reality of the positive data obtained by this method, without attaching finality to its negations. One may admit that where the injection passes, there is a channel, without denying that beyond the limit of injection there are forming channels, or considering it proved that injected channels are always lined by a complete endothelium. One may admit that the blind terminals of vessels are actual terminals, without assuming that they are always sprouts, for they may be regressive. And above all, one may admit the frequency of extravasation, without holding it to be ohne weiteres an artifact. But if these reservations are allowed, or even conceded to be still matters of free and unbiased inquiry, the positive results of the injection method will form but a slender basis for such imposing doctrines as those of the specificity of endothelium, and of the angioblast.

From the time of the establishment of the circulation, the body of the embryo and some of its membranes are supplied with continuous channels which distribute the circulating medium, and 
return it to the heart. From this period throughout life, such continuous vessels are present and functionally active. In the adult body it has long been customary to inject them for convenience in demonstrating their course. In the foetus also, such procedures are familiar and have been held to demonstrate the plan of organization of the circulatory channels at the period of examination. Now it is obvious that the injection at earlier periods, even in young embryos, is a fact of the same order, however admirable the technique or delicate the procedure -it simply demonstrates continuous channels, which it may be presumed are functionally active. It reveals the extent and conformation of the formed and functional vaseular system and enables the observer to follow its successive stages from the period at which injection first becomes practicable. In such studies, however, injection has no monopoly, but it shares its data with the method of direct observation of living tiswe when the olject is small and transparent, and with the exact but laborious method of reconstruction. On the other hand, it is idle to pretend that the injection method throws any light on areas beyond the limit of the actual injection, or affords the slightest presumptive evidence of their histological condition, in particular, as regards the presence or absence of small discrete vesicles of endothelium.

The dilemma is simple; we may recognize or refuse to recognize the uninjectible periphery. If we recognize it, the method of injection becomes not only partial and incomplete, but subordinate to the methods which reveal all of its findings and in ardelition enlarge our field of observation. It ceases to be a critical method. If we refuse to recognize the periphery beyond our injection, we have begged the question at issue, our vessels are growing not only in a foreign tissue, as the angioblast doctrine believes, but in a theoretical racuum and the only posible source of increment is the proliferation of their own elements. We reach the only conclusion the exclusive study of organized vessels by any method would allow, the formation of the new out of the old by sprouting. A comparison may perhaps serve to illustrate the inconvenience of taking continuity of lumen as the critical index of structure. Had the metanephros chanced to 
be first studied by the method of injection, we should have a history of the ureteric bud from the standpoint of its lumen. It would have sprouted, giving branches of many orders, and by growth in continuity its arborizations would in time form their definitive terminals, the Bowman's capsules. Should an investigator, with a belated confidence in slides and reconstruction, have ventured to observe the renal vesicles, he might have been told he had been misled by artifacts. Had he objected that they were constant, had definite structural characters, and were localized with exquisite precision, he might at length have obtained their tardy recognition. But it is probable, for doctrines as well as masses have momentum and inertia, that he would then have been informed, that his vesicles were but separated sprouts, because nephrothelium comes only from nephrothelium. And these arguments would be as justifiable, nay as necessary, in the one case as in the other, if ultimate reliance is placed on the injection method which can only reveal continuity of lumina. The logic is good, the argument the typical scholastic deduction of the special case from the general principle, but the principle is intuitive and arbitrary, not inductive.

The blind terminals of vessels in the mammalian foetus are a favorite topic for study by injection, but so far as I am aware, the possiblilty of their regressive nature has never been seriously considered; it has simply been assumed that they were always growing sprouts. I desire here rather to note the gap in the evidence than to question this mode of growth as a factor in the extension of formed vessels in late embryonic stages and in the fuetus.

W. G. MacCallum² ('02) made a careful and excellent histological study of lymphatic terminals in the skin of pig foetuses, from $6 \mathrm{~cm}$. to $15 \mathrm{~cm}$. in length, and reached the conclusion that the lymphatics did not communicate with tissue spaces. From their extremities project strands of cells in a single or double row which run for some distance in the embryonal connective tissue, or join another lymphatic. He thought that few of these cells were in syncytial relation with adjacent fibroblasts. ${ }^{3}$ Into the

2 1902. Arch. f. Anat. u. Entwickelungsgesch., p. 273.

${ }^{3}$ Exponents of the doctrine of specificity seem inclined to lay stress on this point as indicating the independence of endothelium. In view of the interdermal 
bases of the cords, the injection entered in a thin stream for a short distance revealing a cleftlike diminishing lumen.

Bartels ('09) 4 has given figures which closely correspond to those of MacCallum, but he considers the interpretation of the cell-cords as sprouts debatable. On the other hand,-Miss Sabin's figure of lymphatic terminals in a $5 \mathrm{~cm}$. pig ('02, fig. 2$)^{5}$ represents very different conditions; here are blind, blunt terminals and no sprouts. She states, however, that occasionally from one of these blunt ends, the "injecting fluid can be forced out into a long thread-like process" which is a sprout and represents the process of growth.

she has plainly described a somewhat different structure from the solid uninjectible strands of MacCallum and Bartels, though not improbably a phase of the same process. A number of interpretations suggest themselves:

1. Miss Sabin's, that the slender injectible processes are sprouts growing from formed vessels and that this is the only mode of their extension at this period.

2. That in view of their infrequency, we are dealing with the inception of autonomy on the part of the endothelium, which in a few places is sprouting, while in most it is advancing by accretion, as has been definitely proved for the thoracic duct and the systemic lymphatics in general in embryos. ${ }^{6}$

cytodesmata described by v. Szily, Studnička and others, it is of course void of theoretical importance in this sense, for if in general, elements of different germ layers may stand in syncytial relation to one another, the specificity of endothelium is in no way impaired by a like continuity with the mesenchyme, which in fact it does possesss in the embryo. If in the foetus a separation does actually occur, it ought to be interpreted in the light of the general tendency of the organism to resolve its synctia into independent cells, and not as a peculiar sign of the specificity of endothelium.

4 1909. Das Lymphgefässsystem. Jena. p. 12 .

5 1902, Am. Jour. Anat. vol. 1, p. 367.

${ }^{6}$ Huntington \& McClure, 1907, Am. Journ. of Anat., vol. 6, Abstr. Anat. Rec., vol. 1, pp. 36-41. Huntington, 1908, Anat. Rec. vol. 2, pp. 19-45; 1910, Anat. Rec., vol. 4, pp. 339-423; Compte Rendu 16 Congrès Internat. de Med. Sect. 1, f:ssc. 2, pp. 127-142; Anat. Anz. Ergänz. z. Bd. 37, pp. 76-94; 1911, Wistar Mem: No. 1; Anat. Rec., vol. 5, pp. 261-276. Stromsen, 1912, Anat. Rec., vol. 6, pp. 313-356. Kampmeyer, 1912, Am. Jour. Anat., vol. 13, p. 401, and Anat. Rec., vol. 6, p. 223; McClure, 1912, Anat. Rec, vol. 6, p. 233. Tilney, 1912, Amer. 
3. That the sprouts are regressive and that here, as in other tisues (bone, striated muscle), progressive and retrogressive processes co-exist.

4. That the 'sprouts' are the last stages in the annexation of vasoformative cells which have built themselves into cords, joined the lymphatics and are now establishing their lumen. Only in this last stage would they be accessible to injection. This interpretation is suggestd by Bartels ('09) and is of considerable import. Referring to certain unicellular sprouts of Mac Callum, he says:

Gerade, dass es einzelne Zellen sind, welche die Stränge bilden, scheint mir eher für den Módus der Aufreihung dieser Zellen durch den zentralwärts gerichteten Saftstrom als fur eine zentrifugal gerichtete Sprossung zu sprechen. Doch will ich darauf, als auf eine nach dem bisher Vorliegenden nicht sicher zu entscheidende Sache, ebendsowenig eingehen, wie auf die Beurteilung des Verhaltens der benachbarten Gewebsbestandteile zu den Gefässen. Beides scheint mir weiterer eingehender Untersuchungen zu bedürfen. ${ }^{7}$

None of these observations, important as are the data they have collected, have given us the means of interpretation, once the increment of vessels is conceived as a minute process which must be treated in terms of cells and cell modifications. For this it is necessary to work in confined areas of well understood topography and with a minutely graded and continuous series of embryos. If cords of single or double rows of cells are to be studied developmentally, we must at least give ourselves the chance of seeing cell add itself to cell, or the sprout advance from the unicellular to the multicellular condition, and not work at wide intervals of time or with material from various regions where only gross comparisons are possible and minute processes may altogether escape us.

From the standpoint of possible retrogression, the work of sipuler" and of Fuchs's is interesting and their aloofness from this particular problem gives their testimony additional importance.

Journ. of Anat., vol. 13, pp. 193-220. Miller, A. M., 1913, Amer. Journ. of Anat,, vol. 15, pp. 131-163. Allen, W. F., 1913, Quart. Journ. Mier. Sci., vol. 59, pp. 309-360.

${ }^{7}$ Loc. cit., p. $45 . \quad{ }^{8} 1592$, Arch. f. mikr. Anat., Bd. 40, p. 530.

${ }^{2} 1903$, Anat. Hefte. Band. 22, p. 97. 
They were writing in refutation of Schaffer's derivation of erythrocytes from vasoformative cells and of Minot's $\mathrm{s}^{10}$ expansion of this observation into an absolute distinction between nucleated and non-nucleated red corpuscles, and his classification of blond in the vertebrates on this basis.

Spuler showed clearly that the erythrocytes in question and the vasoformative cells containing them were degenerative. Fuchs, working with the omentum of the guinea pig in the first few days after birth, confirmed these observations. The vasoformative cells of Schaffer ${ }^{11}$ and Ranvier ${ }^{12}$ he found usually connected with functional vessels by narrow cell-strands, with or without lumina. In a few cases the strands were interrupted. This he attributed to rupture occasioned by unequal growth in the omentum. He subscribes to the production of ressels from vasoformative cells but makes a distinction between these cells and the erythrocyte containing cells which he found, as Spuler had done before him, usually connected with vessels. These, in view of their degenerating contents, may fairly be deemed retrogressive. Their occasional occurrence free in the connective tissue then becomes a late and not an early phase in their history. The order of events in a degenerating capillary would appear to be a collapse of its lumen at some intermediate point or points, between or beyond which the vessel and content persist for a time; the solidification and the reduction of the collapsed regions to double or single rows of cells and eventually long protoplasmic strands, which finally give way, and the remnants of lumina with their contents of blood cells and their wall of endothelium become isolated in the connective tissue. Fuch's excellent illustrations are astonishingly like the sprouts of MacCallum and the cell cords of Bartels, differing only in the cellular contents of the vessels (ef. Fuchs, fig. 2, with Bartel's '09, fig. 12, and Fuch's, figs. 4, and 3, with MacCallum, figs. 6 and 7 , respectively).

Identical appearances are observed in definite regions of younger embryos of the cat incident to vascular processes which are

${ }^{10}$ 1890, Anat. Anz, Bd. 5, p. S01. ${ }^{11}$ 1874, Mo. Mic. Journ., vol. 11, p. 97.

12 1874, Arch. de Physiol. 
known to be regressive, because they are preceded by blood containing plexuses and functional vessels and accompany their resolution. Huntington ${ }^{13}$ has noted the condition in connection with the perivenous plexuses:

Some of the elements . . . . develop into permanent tributaries of the main veins. Others undergo a process of separation from the permanent functional channels and degenerate. In many cases their blood cell contents break down and are eliminated, while their endothelial lining appears to revert to the indifferent type of the embryonic mesodermal cell.

Thus in embryos between 13.5 and $16 \mathrm{~mm}$. many striking instances of this reversion are to be observed. [And further] . . . . these detached and retrograding channels . . . . constitute lines around which the most active primary lymphatic organization of the mammalian embryo centers.

I am far from 'wishing to claim that 'sprouts' are never growing points, I would only instance cases where they certainly are regressive, and express the doubt that their injectibility or lack of it affords a proof of their origin from endothelium. The subject is a promising one and would repay unprejudiced observation under conditions where the direction of the process might be definitely ascertained-in a circumscribed area and with a closely graded series of foetuses. It may be that their formation in the lymphatic system will prove to be a late phenomenon and incident to the ultimate sealing off of the lymphatios from the tissue spaces, if a closed system of lymphatic capillaries actually exists.

The question of extravasation is perhaps the most difficult of the many problems the injection method has raised, and is giving us a literature of as much subtilty in connection with developing vessels as it has done in regard to the circulation in the adult spleen. The point at issue is not the permeability of the vessel wall which may be taken as proved beyond controversy by the facts of metabolism, and the passage of erythrocytes and leucocytes, as well as by the results of injection. The real difficulty is as to how we may accept these indisputable facts and yet maintain that when extravasations occur during injection they prove a discontinuity between the lumen of the vessel and the tissue space in mesenchyme or in connective tissue.

18 1911, Memoirs of the Wistar Inst. of Anat. and Biol. No. 1., Philadelphia. 
The positive conclusion that extravasation means communication between resiel and tissue space seems justified when the injection is controlled by a manometer and practised at physiological or subnormal pressure, as in Herring and Simpson's' ${ }^{14}$ injections of the liver or Pustoiwoitow' $\mathrm{s}^{15}$ of the spleen. If, as in these cases, the injected substances escape under less than normal pressure it is permissable to infer a real continuity, though strictly speaking it is necessary to confirm this by direct observation of the tissue (vide infra).

But if the pressure is not thus controlled, it will always be possible to interpret the extravasation as an artifact, for it can always be argued that rupture occurred under excessive pressure. Centrifugal injections of lymphatics are obviously subject to this doubt, so that the presence here of extravasation is only suggestive and not demonstrative of communication between these terminals and the tissue spaces.

Other methods of control than that of manometric measurement of the pressure can not be freed from subjectivity. To observe, for example, the passage of the injection with a binocular and discontinue when it begins to extravasate is arbitrary; to succeed in stopping at the moment when extravasation has just begun, when the terminals have still but a mossy appearance, shows only the point to which the observer's dexterity may be developed. One may, with practice, heat a thermometer rapidly till the mercury rises to a chosen point, and become able to discontinue just as the point is reached. The repetition of the act may increase exactitude, but will not prove the absence of luminal continuity beyond, however we might argue, when we had just passed our selected point, that we had ruptured a delicate and invisible membrane.

Nor is even the "explosive" (MacCallum) rupture of the vessel wall at some intermediate portion of its course a proof that its terminals are closed. A very moderate experience with the injection of adult material will convince anyone that large veins may rupture before their radicles are filled, and the rupture may

141906 , Proc. Roy. Soc. B., vol. 78.

${ }^{15}$ Arch. f. Anat. u. Entwickelungsgesch., p. 219. 
be attended with sensations, even emotions, on the part of the observer. Yet it cannot thereby be proved that the vessels end blindly; and we ought not to assume, because of the delicacy of embryonic structures that their physical properties are different in kind, or obey other general laws of stress and strain than larger tubes which are more accessible to examination.

But while the results of injection demonstrate the permeability of the vessel wall, as do in life the passage of cells and fluids, they do not afford us the opportunity of ascertaining the structure of the wall or the nature of its orifices. They simply give us the concept of permeability, which it is not permissible, without further grounds, to translate into porosity. Every fact of extravasation can be admitted and the integrity of a completely closed vessel wall still be maintained if we introduce the concept of a structureless (invisible) membrane, the resistance of which to pressure is practically nil.

Helly ${ }^{16}$ has shown this with admirable clearness in his interesting work upon the vessels of the spleen. He confirmed previous observations of the passage of injections through the ressel walls, whether solutions, suspensions, colloidal masses, or foreign blood corpuscles were used. He further washed out the red blood corpuscles from the pulp spaces by saline irrigation, and caused their numbers in the pulp to increase by retrograde injection (obstruetion of the splenic vein) and finally in sections of $5 \mu$ observed both erythrocytes and leucocytes in pasiage through the walls of the sinuses. Yet he considered the wall complete.

Was zunächst den Widerstand anlangt, welchen die Gefässwand dem Durchtritte fester und flüssiger Bestandteile entgegenzusetzen vermag, so ist ersichtlich, dass derselbe bei den venösen Capillaren nur sehr gering, an gewissen Stellen der Wand überhaupt fast gleich null ist; gleicht sie doch, von der Fläche betrachtet, sehr einem Gitter, dessen Lücken vielfach gross genug sind, um ein rotes Blutkörpcrchen ohne jede merkliche Formveränderung durchtreten zulassen. Dem zwischen beiden Bestandteilen des Gitters, - den imneren, parallel zur Längsachse des Gefässes angeordneten, stabförmigen Endothelzellen und den äusseren, quer um dasselbe verlaufenden Kreisfasern,--befindliche unmessbar dünnen strukturlose Häutchen kann wohl kein irgend nennenswerter Einfluss im Sinne einer Behinderung der Diapedese zugeschrieben werden und dies umso weniger, als das gedachte Hïutchen sehr hinfällig ist

161903 , Arch. f. mikr. Anat., Bd, 61, p. 215. 
und ungemein leicht zerstört wird. (p. 292) . . . . Die Milz hat ein, überall von einer regelmäsigen Endothelshichte ausgekleidetes, daher geschlossenes Gefisssytem mit sehr durchläsigen II andungen.

Den ich habe einerseits gezeigt, dass man unter Anwendung geeigneter Methoden sich davon überzeugen kann, dass der kreisende Blutstrom überall seinen Weg durch Capillargefässe nimmt, deren wand keine Oefinungen in (isstalt beständiger Lücken für den Durchtritt rother Blutkörperchen zeigt, welcher dort, wo er der unmittelbaren Beobachtung zugänglich ist, als wahre Diapedese aufgefasst werden muss; andererseits habe ich den Durchtritt von Leukozyten durch die geschlossenen und unversehtren Gefässwande hindurch als thatsächlich vorhandene Erscheinung nachgewiesen. ${ }^{17}$

It will thus be seen that Mall ${ }^{18}$ fails to appreciate the subtilty of the question and at the same time misrepresents Helly in citing him as a believer in pores in spite of his emphatic statement to the contrary:

. recent authors are of one opinion regarding the large pores in the capillary walls. It appears that these openings are smallest according to Thoma, larger according to Helly, still larger according to Mall, and so laree that they eommunicate mast freely with the julpspaces according to Weidenreich.

Helly very carefully distinguishes between permeability and porosity, refuses to deduce the details of structure from physical and physological properties, and accepts the structureles membrane of $\mathrm{v}$. Ebner because he believes he has seen it. Mollier ${ }^{19}$ correctly represents Helly's position and criticises it with arumen:

Ob es freilich noch praktischen Zweck hat, von einer geschlossenen Riohre zu sprechen, wenn sie fastohne Widerstand alle zelligen Elemente in unbegrenzter Menge hindurchlässt, könnte zmeifelhaft erscheinen. Weidenreich hält jedenfalls eine solche Annahme für wertlos, wie ich aus seiner temperamentvollen Ausserung entnehme: 'Ein Sieb ist doch kein Topf.'

Ich meine aber, er vergisst hier, dass ein wesentlicher Teil unserer Vorstellung iiber den Vorging der Diaperlese der ist, dass Zellen durch die Capillarwand den Kreislauf verlasson, ohne dass dabei nennenswerte Mengen des Plasmas mit austreten. Der Kreislauf der Blutflüssigkeit wird also kaum beeinflusst.

Von diesem Gesichtspunkt aus hat die Annahme Hellys nicht nur ihre Berechtigung, sondern auch einen ganz bestimmten technischen Wert. Ob die Bezeichnung Diapedese auch für den Durchtritt roter

\footnotetext{
${ }^{17} 1902$, Arch. f. mikr. Anat., Bd. 59, p. 93.

18 1903, Am. Jour. Anat., vol. 2, p. 315.

${ }^{19} 1911$, Arch. mikr. Anat., Bd. 76, p. 609.
} 
Blutkörperchen ohne lokomotorische Eigenlsewegung gebraucht werden kann, dariber will ich hier nicht weiter sprechen. Wir haben bloss damit zu rechmen, dass Helly den Durchtritt roter Blutkörperchen (auch Froschblutkörperchen) durch die unversehrte Wand der venösen Milzcapillaren gesehen hat und dass er hierin ein Hauptargument für die Lehre vom geschlossenen Kreislauf in der Milz erblickt.

To summarize, the injection method gives us extravasation. This has a positive value when physiologic or subnormal pressures are used. It proves the permeability of the vessel wall. For the structure of that wall, whether complete or incomplete anatomically, and especially for the ultimate morphologic fact, the form and relation of its constituent elements, it is valueless and these questions must be settled by direct observation, and not by indirect conjecture founded upon physical or physiological experiment. To quote Mollier again, referring to the question of open or closed circulation in the spleen:

Welcher Art diese Untersuchungen sein müssen, ergibt sich einmal aus dem Resultat der Injektionsversuche, welche lehren, das dieselben immer wieder sowohl zugunstęn der einen wie der anderen Anschauung Beweismaterial geliefert haben. Sie sind also wohl nicht imstande, diese Frage zu entscheiden, und es ist besser, von ihnen zunächst ganz abziisehen. ${ }^{20}$

His own brilliant solution of the problem of the structure of the sinus wall, is a ground of confidence to those who hold that structural problems are best approached by anatomic methods. In view of the complexity of structure and function in living beings, it will probably continue to be held the part of wisdom to determine their relation empirically and not attempt to deduce structure from the physical or even the physiological properties of organs and tissues.

The positive findings of the injection method, that there are in the embryo contimuous vasular channels, that these channels have ends, and their walls are very pervious, can therefore be accepted for they are corroborated by other methods of investigation. The negative propositions that have been advanced by users of this method, that the embryo has only continuous endothelium, that its only source is from sprouts, that the ends of vessels do not communicate with tissue spaces, are not proved

${ }^{20}$ Lne, cit. 
by the evidence which is alleged to support them. The method is partial in that it excludes a rasculogenetic periphery beyond its limit of exploration, uncritical in that it can only reveal permeability and not the structure of the vessel wall, and its advocates are inconsistent in that without just grounds they interpret its only peculiar datum, the extravasation, as an artifact.

Nor does the doctrine of specificity receive more support from observations intra vitam, if we distinguish between the growth and the formation of a tissue, and refrain from transferring processes recorded of a given stage, perhaps a late one, to earlier periods in ontogeny.

The observations upon the tails of amphibia, especially the tadpole, a classical object since the days of Schwann, have accumulated a rich fund of observations regarding the sprouting both of blood vessels and of lymphaties. Kölliker, ${ }^{21}$ Rouget ${ }^{22}$ and Golubew ${ }^{23}$ followed the process, step by step, describing the hollow-pointed outgrowth, its acquisition of a lumen and its fusion with adjacent sprouts. The sprouts were found to arise, not only in the vicinity of nuclei but also at a distance from them (Köllicker, Flemming) $;^{24}$ in the latter event nuclei were found subsequently to move into the sprouts (Fleming, Bobritski). ${ }^{25}$ r. Ebner, in his edition of Kölliker"s Handhuch, summarizes these findings and interprets them correctly as phenomena of growth:

Die Sprossung muss demgemäss als ein Wachsthumsvorgang des Protoplasma angesehen werden, denn auch in den Fällen, wo der Kern an der Sprossungsstelle liegt, lässt sich zunächst nichts von einer Kerntheilung sehen. MIan muss wohl die primären Sprosse als sich aushöhlende Protoplasmaknospen einer Endothelzelle ansehen. Erst sekundär erfolgt dann eine Mitose in der Zelle des Muttergefässes und der eine Tochterkern tritt nachträglich und nachdem er bereits wieder zu einem ruhenden Kerne geworden, in den Gefässspross, der unterdessen weiter gewachsen ist, ohne dass eine Zelltheilung erfolgt, da man, wie bereits erwahnt wurde, in jungen eben sich bildenden Kapillaren keine Zellgrenzen nachweisen kann. ${ }^{23}$

${ }^{21} 1846$, Ann. S. se. natur., T. v. p. 91. 1S\$6, Zeitschr. f. wiss. Zool., Bd. 13 , p. 1.

22 1873, Areh. de I'hysiol.

${ }^{23}$ 1869, Arch. f. mikr. Anat., Bd. 5, p. 49.

${ }^{24} 1890$, Arch. f. mikr. Anat., Bd. 35, p. 283.

${ }_{25} 1855$, Central bl, f, mikr. Anat.

${ }^{26}$ Loc. cit, p. 672. 
Schwann had believed that the capillaries were formed by the fusion of stellate cells, and Kölliker held at first the same view, but later abandoned it and considered the new formation of vessels in the tadpole's tail wholly due to sprouting.

Sigmund Mayer made an important addition to our knowledge of the vascular system in his thorough study of its regressive processes. He distinguished between blood containing and blowlless resisels in the tadpole's tail, and pointed out that not all of the latter were to be taken as lymphatic, for many of them were degenerating blood vessels. The changes in the circulation incident to their collapse supports this riew. His figures show many stages of their reduction and present striking resemblances to those of Fuchs, Mace "allum and Bartels, before mentioned. Some confusion has been introduced into the terminology of these structures by Miss Sabin"s who has invented the term "MayerLewis anlage" to include these degenerating vessels and the endothelial sacs described by Lewis in the course of veins in the mammal. It will be remembered by the readers of $\mathrm{F}$. T. Lewis'29 valuable paper that he found the jugular lymph sac composed of several cavities, at first connected but later separated from the veins. Similar sacs were found adjacent to many of the veins, for which he assumed a like origin although he is most careful to state that in no single instance, other than at the jugulo-subclavian junction, was there any evidence of connection with veins.

IIiss Sabin has further extended this concept to include the discrete mesenchymatous anlages of the lymphatics, described by Huntington and McClure, which have at least a totally different structure from the formations described by Mayer. Their walls present every degree of transition from mesenchyme to fully formed endothelium and every degree of communication between their carities and the spacès in the adjacent mesenchyme. They do not run off into long tapering processes, and they do not contain degenerating erythrocytes. It is highly probable

${ }^{27}$ 1S5, Sitz-Ber. Akad. wiss. Wien. Bd. 91, p. 20 t.

${ }^{2} 1911$, Anat. Rec., vol. 5, p. $\$ 17$.

${ }^{29} 1906$, Aner. Jour. Anat., vol, 5, p. 95. 
that they are identical with the structures observed by Lewis, absolutely certain that they are not the same as the degenerating vessels of Mayer and Fuchs. The degenerating ressels described by Huntington in the cat have a wholly different appearance and to one familiar with the study of sections, the danger of confusing the two seems inconsiderable. With the aid of reconstruction and the comparison of closely graded embryos to ascertain the direction of the process, it is difficult to conceive of a possibility of so gross an error. In passing, I would note that the term anlage has hitherto been applied to the developmental process as indicating the earliest appearance of an organ. It is quite improperly used in connection with regressive structures.

Iore recently Clark ${ }^{30}$ has published painstaking and elaborate studies of growing lymphatics in the tail of the tadpole, containing many interesting details and in major matters confirmatory of the work of his predecessors. We may therefore conclude that the ressels of the tail fin are formed by sprouting and that there is no evidence for the annexation of mesenchyme cells at this stage.

The debate is again not as to the fact, but solely in regard to the constrution that shall be put upon it, and in particular the degree to which such observation: may be extended to endothelium in general.

Goette $^{31}$ described the first formation of vessels in amphibia from clefts in the mesoderm, which secondarily acquire a wall from adjacent cells and from intravascular wandering cells. Marshall ${ }^{32}$ and Morgan ${ }^{33}$ have reached similar conclusions, and recently Studnicka $a^{31}$ has described the formation of the capillary as a channel in the mesostroma, into the wall of which cells migrate eventually forming an endothelium:

Ganz ähnlich verhält es sich auch mit den Blutkapillaren, welche jedenfalls sehr früh, wenn das Mesostromanetz noch ziemlich locker ist, zum Vorschein kommen. Die Bilder, die ich an meinen Objekten finde, sprechen durchaus nicht dafür, dass es ausschliesslich nur die Zellen

\footnotetext{
30 1909, Anat. Rec., vol. 3, and 191', Am. Jour. Anat., vol. 13.

31 1875, Die Entwickelungsgeschichte der Unke. Leipzig.

32 1890, Stud. Biolog. Lab. Owens College 2: 1893. Vertebrate embryology.

${ }^{33}$ 1897, The development of the frog's egg. New York

34 1911, Anat. Anz., Bd. 40, p. 33.
} 
wären, welche, wie man est meist annimmt, sich röhrenförmig zu Kapillaren umbilden würden; alles spricht dafür, dass die Kapillaren im Mesostromanetz auch dort, wo keine Zellen vorhanden sind, also ohne jede Beihilfe von Zellen weiterwachsen, und ihre Wand besteht da aus ciner einfachen, zuerst plasmatischen Schicht, welche jener vollkommen entspricht, aus der sich z. B. das Corium bildet. Die Zellen sind in der Wand der jungen Kapillaren zuerst weit voneinander entfernt, und nur so, dass sie sich später vermehren und die innere Oberfläche der früher schon vorhandenen Kapillaren sekundär bedecken, kommt die Endothelauskleidung derselben zustande.

It is evident therefore that the processes in the tadpole's tail are not characteristic of all stages even in amphibia, and that much caution is requisite in attempting to generalize from such data. In the light of our present knowledge, far from extending these findings into a principle of vascular development, it would seem more prudent to seek to ascertain the peculiar conditions in larval organs which may serve to explain a deviation on the part of the mesenchyme cell from its usual behavior to developing vessels.

The transparent embryos of teleosts also afford a favorable opportunity for the study of living vessels. Wenkebach ${ }^{35}$ has recorded important observations, especially upon Belone longirostris, and finds that mesenchyme cells are an important factor in the formation of vessels and sprouts.

Man sieht deutlich wie die Zellen, namentlich die des Mesoblasts, selbständig mittelst amoeboïder Bewegungen und oft ausserordentlich langer protoplasmatischer Fortsätze sich im Körper des Embryo und auf dem nicht mit Hypoblast umkleideten Dotter bewegen und nach bestimmten Stellen kriechen, als handelten sie mit Wille und Bewusstsein. Bei der Anlage und weiteren Ausbildung des Herzens, so wie bei der Bildung der Gefässe und andrer Organe spielt diese selbständige Bewegung der Mesoblastzellen eine grosse Rolle.

Nicht alle 'Zellen, die von dem Embryonalsanm auswandern bilden Pigment. Eine sehr grosse Zahl derselben zerstreut sich uber die Oberfläche des Dotters und diese sind als Material für die später sich dort bildenen Blutgefässe zu betrachten.

Aus diesen Beobachtungen geht hervor, dass Mesoblastzellen durch selbständige amoeboïde Bewegungen die Wände der Blutgefässe des Dotters bilden.

Endlich werden die ersten circulirenden Zellen auch benutzt bei der Sprossenbildung der Dottergefässe. Die drei auf dem Dotter vorhan-

so 18s6, Arch. miki. Anat., Bd, 25, p. 225. 
denen Gefässe fangen namlich schon bald an kleine Seitenzweigchen zu bilden (Fig. 12 u. 13). Eine solche Sprossung wird eingeleitet von einer kleinen Ausbiegung der Gefässwand (verg. Fig. 25 a, b, c, d, e. und f.), an deren Spitze sich immer eine Zelle befindet. In dem Maasse als die Sprosse wächst, lagern sich immer neue, aber nicht sehr zahlreiche Zellen an dieselbe an, welche sich auf die schon oben beschriebene Veise ausbreiten, sich mit langen Fortsätzen an einander haften und so die Wand herstellen. Hierfür werden sowohl die vom Blutplasma herangefuhrten, als die sich schon auf dem Dotter befindenden Zellen verwendet. Diese letzteren Zellen scheinen eine grosse Neigung zu haben, Gefässe zu bilden, denn einige Male beobachtete ich, wie sich in diesem Stadium der Entwicklung freie, sich auf dem Dotter befindende Zellen, unabhängig von schon vorhandenen Gefässen, zusammenlagerten und kleine Röhrchen bildeten, welche später in das System der Dotterblutbahn eingereiht worden.

In diesem prachtvollen klaren Embryo sah ich auch die Bildung der kleineren Gefässe im Embryo selbst. IVie aus Figur 24 hervorgeht, bilden sich hier die kleinen um das Medullarrohr ziehenden Gefässehen ebenfalls aus Zellen, welche sich mittelst amoeboïder Bewegungen zwischen den Theilen des Embryo hinziehen.

In their general features these observations were confirmed by Raffaele: ${ }^{36}$

Le osservazioni fatte dal Wenckebach e già tante volte citate, e che io ho potuto in varie occasioni ripetere con risultati del tutto concordanti su varie uova di Teleostei, dimostrano chiaramente la migrazione di cellule mesenchimatiche in siti molto lontani dal punto di origine; ed è con questo processo che si formano tutti i vasi del vitello, compreso il cuore, il quale in taluni pesci ossei (Belone) si forma innanzi alla testa dell' embrione e in parte sul vitello.

From the foregoing, it would appear that in teleosts also there is the closest affinity between mesenchyme and endothelium, and that here sprouting from a formed and specific endothelium hardly plays a rôle in early stages of vascular formations.

A few other intra vitam observations may be noted briefly. MelVhorter and Whipple were able to show and record photographically the concrescence of separate vascular anlages in the area pellucida of the chick's blastoderm in vitro. This confirms Afanassiev's ${ }^{37}$ and Klein's ${ }^{38}$ observation of endothelial vesicles and seems an adequate refutation of Evan's opinion:

36 Mitt. Zool. Stat. Neapol. Bd. 10, p. 411.

37 1S69, Bul. de l'Acad. des Se. d. St. Petersbourgh, T. 13, p. 321.

38 1571, Sitz.-Ber. Akad, wiss. Wien, I3 1. 63, 1). 3399. 
Selbst auf dem Dottersack sind solche Gefässe, welche in loco entstanden sind, nicht zahlreich, denn sie entstehen nur an den Stellen der sogenannten "Anlagen," und die Hauptmasse des Kapillarplexus des Dottersacks entsteht durch Ausbreitung und reichliche Anastomosenbilldung von den primären Gefässen aus. ${ }^{39}$

Further, the description by MeWhorter and Whipple ${ }^{40}$ of the to and fro movement of red corpuscles after the heart had begun to beat and prior to the establishment of the circulation points to their confinement in separate compartments. Their subsequent abrupt entry into the blood stream, must mean the giving way of the wall of the vesicles and their confluence to form vessels - all which is consonant with the data obtained from sections and reconstructions, and seems to afford a basis of interpretation for an interesting observation of Loeb's:41

It turned out in my experiments that the heterogeneous hybrids between bony fishes formed eyes, brains, ears, fins and pulsating hearts, blood and blood vessels, but could live only a limited time because no blood circulation was established at all-in spite of the fact that the heart beat for weeks - or that the circulation, if it was established at all, did not last long.

I succeeded in producing the same type of faulty embryos in the pure breeds of a bony fish (Fundulus heteroclitus) by raising the eggs in $50 \mathrm{cc}$. of sea water to which was added $2 \mathrm{cc}$. one one-hundredth per cent, NaCN. The latter substance retards the velocity of oxidations and I obtained embryos which were in all details identical with the embryos produced by crossing the eggs of the same fish with the sperm of remote teleosts, e.g., Otenolabrus or Menidia. These embryos. which lived about a month, showed the peculiarity of possessing a beating heart and blood, but no circulation.

These findings of Loeb can hardly be reconciled with the doctrine that the vessels of the embryo have a primitive continuity of lumen with those of the yolk-sac, for it is inconceivable that in such circumstances, a beating heart could fail to effect a circulation. They are however corroborative of the observations of McIVhorter and Whipple which would lead us to interpret the condition as a Hemmungsbildung due to failure of concrescence

${ }^{30}$ 1912, In Kieibel u. Mall. Entwickelungsgesch. d. Menschen, Bd. 2, p. 552.

40 1912, Anat..Rec., vol. 6, p. 121.

"1912, Pop. Sci. Mo., vol. so, p. 5. 
between the separate anlages of the rescels in the yolk-sac and in the embryo.

Very recently . Niller and Mc.Whorter have demonstrated the formation of the embryonic vesiels in situ and their absolute genetic independence of those of the area vasculosa in the chick, by effecting a separation on one side between the body of the embryo and its membranes at a very early period, before vessels have appeared in the area pellucida. In their experiments, the blastoderm is incised longitudinally near the primitive streak. The wound gapes widely and the area vasculosa is separated from the embryonic body by a wide interval, which no sprouts cross. Notwithstanding which, the embryonic ressels are formed typically, and differ from those of the normal side only in size and rate of development, both of which details may be correlated to their reduced drainage area and the in consequence diminished quantity of circulatory fluid.

It would seem therefore that the limitations of injection and the data of intra vifam methods are hardly favorable enough to the doctrine of specificity, hardly discordant enough with the finding by the method of slides and reconstruction, ${ }^{43}$ to attribute differences of opinion in these matters wholly to the methods

12 Abstract, Proc. Am. Ass. Anat., Anat. Ree., vol. 8, no. 2.

${ }^{43}$ E. R. Clark has endeavored (Anat. Rec., vol. 3, 1909) to show that fixation gives interruptions in the course of vessels which have previously been ascertained to be continuous by direct observation intra vitam. "A drawing was made of lymphatic and blood vessels during life. The tail was then cut into serial sections ten micra thick, stained in hemotoxylin and Congo-red. In attempting to reconstruct it was found while blood capillaries, could often be fairly well constructed, it was impossible to reconstruct the lymphatics beyond the muscular margin." In a second paper (Anat. Rec., vol. 5, 1911) Clark shows evidence of retrograde progression in this line of technique, for the blood vessels in his 3,6 , and 7 figures can hardly be considered "fairly well reconstructed." There are no technical procedures that will not miscarry and such tests as Dr. Clark's are critical of personal accomplishment and judgment not of method in the abstract. In view of the technical difficulties offered by amphibian material, and the fact that none of the data on which the theory of concrescense is based are derived from this form, Dr. Clark's criticism is both unfair and far from the point. With the same plausibility he might have proved that good sections could never be cut, because the yolk of frog's eggs is very likely to tear in paraffin. There is a relation between method and material, to disregard which for controversial purposes shows more of zeal than of sound reason. 
employed. I have already expressed a doubt that this was the case and have suggested that different principles of interpretation were at the root of the difficulty, and I believe that the fault lies with the upholders of the doctrine of specificity, in their too great confidence in the uniformity and simplicity of ontogeny, in their failure to distinguish between genesis and growth, and in the prematurity of their assertion that endothelium is specific, before they have canvassed its potentialities and seriously studied its regressive phases.

The tendency to minimize the period of development, while the natural outcome of reliance upon injections which reveal only formed endothelium and continuity of lumina, has given the theory of specificity a strangely preformist character. Consistently carried out, it would reduce the history of endothelium to the expansion and ramification through the body of a single anlage, produced at a distance from the embryo in the mesoderm or from the entoderm of the yolk-sac. The innumerable separate anlages here, and their gradual concrescence are supported by a weight of evidence impossible to set aside, but the facts seem easier to be borne when this multiplicity is veiled as far as possible by using the term 'anlage' in the singular number and the collective sense. Yet even this 'anlage' proves unable to account for all the vessels of the embryo by its expansion, though Evans feels that most of those in the splanchno-pleure are formed by sprouting. Exception must of course be made of the early ones in the area opaca, the 'anlage' itself, and those in the area pellucida which McWhorter and Whipple have shown are formed by concrescence.

Still there are further difficulties, certain vessels of the embryo arise in situ - the aorta in the head, the first arch, parts of the dorsal aorta, perhaps the heart; it is possible to attach too much importance to the early connection of the caudal portion of the aorta with the splanchnopleuric plexus (in chicks of 20 somites, Evans), and in the face of very general evidence of in situ origin it can only be maintained that any vessels which have not been individually proved to arise in loco are derived by ingrowth from the 'anlage,' with the lumen of which their lumina are shown by 
injection to be continuous, when injection becomes practicable. From this moment $(20$ somites in the chick is the earliest recorded 'perfect' injection of Evans ${ }^{44}$ ) there is a sudden and abrupt end to the production of discrete anlages, contrary to what one would expect from the general gradual transitions in natural processes. All of the endothelium is now continuous, development in the sense of genesis has ceased, and growth alone takes place from this time forward. The moment at which injectibility is acquired is then the critical point in the whole history of endothelium.

But in view of the many separate anlages, admittedly present in the splanchno-pleure and in the embryo and of the transitions, almost universally observed in natural processes, the possibility must be conceded that a belated vesicle or two of endothelium might conceivably escape a sudden annexation to the injectible system. It becomes, therefore, a matter of interest to determine its status after injection has been practised and it has failed, hypothetically, to be injected. A moment before, had it been observed in vitro, or had the blastoderm been sectioned, it would have appeared like any of the other discrete anlages in the 'anlage.' But the test of injection made, it at once ceases to have a future, it has become an artifact, or if pertinaciously insisted upon, a 'Mayer-Lewis anlage.' Because by a hair's breadth, by the veriest fraction of a second, it failed of concrescence prior to the moment of injection, it is absolutely devoid of vascular potentialities, and could never, had the injection been omitted, have joined its fellows and participated in the formation of the vascular system.

But our belated vesicle loses more than its future, it can hardly be said to have a real present existence. When the injection is made, it stands a chance of never being seen by the injector. The injection is then 'perfect.' If it is seen, it is an 'artifact,' or the injection is not 'complete.' If it is pointed out by another observer, then again the injection is incomplete, or it is a 'MayerLewis anlage' and has lost a previous continuity with the injected vessels. All possibilities have been thoughtfully canvassed by the exponents of injection, and it can be confidently asserted that

\$1909, Amer. Jour. Anat,, vol. 9, p. 281. 
a perfect injection injects all the endothelium present; if more is found, then the injection is a failure but the principle remains unchanged.

There is, however, no reason to assume that injection has reached the acme of delicacy, great as is the skill which has been developed in its use. It is conceivable that some day it will be possible to inject a portion of the 'anlage' before its admittedly discrete vessels have fused-even a small fragment might be injected alone, the aorta in the head say, or the umbilical vein. This would then become to the injectionist the only source of the whole vascular system. The uninjected parts of the anlage would be demonstratedly not vascular arlages at all, but artifacts or 'Mayer-Lewis anlages' and no study by slide or section could establish their right to serious consideration; they would be in the same status as the separate anlages of the thoracic duct, or any of the mesenchymatous vesicles of Huntington and McClure, and no degree of care in topographical localization, no minuteness in the gradation of reconstructed stages, no matter how fully their enlargement, gradual approximation and fusion were shown, would suffice to prove their participation in the formation of vessels. If not injectible they can never become endothelium. But the discrete vesicles and blood islands of the splanchno-pleure are as an actual fact not injectible from the first and their structure is hardly known apart from sections. It would seem to be a reasonable and consistent conclusion from the injectionist standpoint, that the 'anlage,' in the splanchno-pleure is an artifact or a 'Mayer-Lewis anlage,' and has absolutely' nothing to do with the vascular system, which should consistently be held to come into being ex abrupto with the first moment of injectibility, for the chick, at present, the stage of 20 somites.

But some may not feel themselves obliged to confine their knowledge of endothelium to such facts only as can be corroborated by injection, for there is a stage of vascular genesis admittedly inaccessible to injection, and here the method of section and reconstruction has acknowledged validity and further is entirely consonant in its results with the data of intra vitam observation. 
This granted, it is arbitrary to assert, that injection once it becomes practicable, dispenses us from the examination of the periphery beyond the terminus of the injection, where it is possible, where there is even antecedent probability that processes analagous to those in the 'anlage' continue and play an important rôle in the increase of vessels within the embryo. Whether this is true or not must be decided by the methods which do not prejudge the question. As in the case of the 'anlage' the results of the study of sections are in agreement with intra vitam findings, it is but reasonable in later stages and in the body of the embryo, where intra vitam methods are as yet inapplicable, to credit the method of sections and reconstruction with the same validity it is proved to possess in early stages.

To deny this, and insist that the limited field explored by injections is alone accessible to investigation, is not to assert the primacy of the injection method, but to fall back upon an ancient logical device known as the petitio principii.

The final objection and absolute disproof of the doctrine of specificity is the heterogeneity of the products to which endothelium gives rise..$^{45}$ I have already mentioned Huntington's description of the conversion to mesenchyme of regressive vessels in embryos of the cat (vide ante, p. 12).

Aurel von Szily ${ }^{46}$ has described and illustrated the production of mesenchyme from the endothelial tube of the heart. And to pass over other investigators who have glanced the subject, Mall ${ }^{47}$ has recently followed the process in detail and noted its theoretical importance.

The great importance of this distinction is at once apparent for it shows that connective tissue arises also from endothelial cells and that the intima of the entire vascular sytem including the valves of the heart has a like origin.

Further study will probably show that endothelial connective tissues are by no means of rare occurrence.

These observations of $\mathrm{v}$. Szily, Huntington and Mall are of decisive importance and seem finally to dispose of the doctrine

45 The idea that endothelium gives rise to conne stive tissue was clearly expressed as carly as 1572 by Franz Boll. Arch. f. Mikro. Anat., Bd. 8, p. 53.

46 1903, Anat. Anz., Bd. 24, p. 417, cf. esperially figure?.

17 1912, Amer. Jour. Anat. vol, 13, p. 249. 
of the specificity of endothelium, for it is fatuous to predicate specificity when products deviate in form and function from the type of the parent tissue.

Of even greater import, because evincing an identity of potentialities on the part of mesenchyme and endothelium, are the recent investigations in haematopoesis, especially those of Maximow, ${ }^{48}$ Dantschakoff, ${ }^{49}$ Mollier ${ }^{50}$ and Weidenreich. ${ }^{51}$ The last ('11) has published a comprehensive critical review of the modern literature of the white blood cells. The extent and variety of the evidence and the number of observers render impressive their concordant testimony to the mesodermal origin of blood cells, in the yolk-sac and the mesenchyme of the embryo, in the liver, spleen and lymphnodes, together with their frequent derivation from endothelium, and in a word the equivalence and permutability of mesenchyme, endothelium and blood cell. A few quotations from Weidenreich may serve to substantiate these statements (the italies are his): •

Jedenfalls entstehen also schon in den frühesten Entwickelungsperioden durch Abrundung und Loslösung aus dem Verband der Mesenchymzellen gleichfalls 'primitive Leucocyten,' die teils den innerhalb der Blutbahn circulierenden völlig gleichen, teils in Grösse und Kernform differieren. Der Mutterboden dieser extravasculär gebildeten Elemente ist aber seiner Art nach durchaus derselbe, wie der der intravasculär entstehenden; denn sie entstammen beide mesenchymatösen Zellen, sei es nun, dass sie sich direkt aus den Blutinselelementen absondern oder sekundär aus dem Endothel der Blutbahnen hervorgehen. . . . . Es ist ferner von besonderer Wichtigkeit dass übereinstimmend angegeben wird, dass neben den ungranulierten primitiven Lencocyten rerhälnismässig frühe auch schon granulierte Formen angetroffen werden, aber und das ist wesentlich nicht imerhalb, sondern uusserhalb der Blutbahn; es gehen

48 1906, Arch. f. mikr. Anat., Bcl. 67, p. 60s, 1907, Fol. hacmot. Bd. 4, p. 611; and Beit. z. Path. Anat. u. allg. Pathol., Bd., 41, p. 122. 1909, Arch. f. mikr. Anat., Bd. 73, p. 44t; and idem, Bd. 74, p. 525 and Fol. haemotol. Bd. 8, p. 125; and Centralbl. f. allg. Pathol. u. path. Anat., Bd. 20, p. 145. 1910, Arch. f. mikr. Anat., Bd. 76, p. 1; and Verh. Anat. Ges. Brussel, S. 64.

40 1908, Anat. Hefte, Bd. 37, p. 473; Arch. f. mikr. Anat. Bd., 73, p. 117. Vehr. Anat. Ges. Ber., 1908, p. 72. 1909, Arch. f. mikr. Anat., Bd. 74, p. S55. Vehr. Anat. Ges. Brussel, 1910, 1), 17.

so Loe. cit.

51 Die Leucocylen und verwandle Zellformen. Weisbaden 1911. Sonderausgabe aus Merkel u. Bonnet, Ergeb. d. Anat. Bd. 19, Abt. '2. 
also hier die granutierten Elemente zunächst aus leucocytären Wanderzellen $\mathrm{d}$. h. freigewordenen Mesenchymzellen hervor. ${ }^{52}$

In the Liver:

Die 'primitive Blutzelle, die sich abrundende Mescnchym-oder Reticulumzelle, die undifferenzierte 'Gefässwandzelle' ist überall dasselbe Element, es erscheint bald als Begrenzung einer Reticulummasche, bald als W and einer schon etwas kanalisierten Blutbahn, bald als freie Blutzelle; genau die gleichen Verhaltnisse kehren also in der Leber wieder, wie man sie in den Blutinseln und Blutsträngen und den ersten Gefässanlagen des Mesoblasts findet, nur mit dem Unterschiede, dass hier Entodermzellen in Form der Leberanlage einwachsen und das Ganze mehr zerteilen. Als wesentlichstes Ergebnis ist sonach festzuhalten, dass rote Blutkörperchen and Leucocyten von einer 'Lelle mit mesenchymatischem Charakter gebildet werden. Die Frage, ob sie beide oder nur die eine extra, oder intravasculär entstehen, ist nach der eben erörterten Auffassung ziemlich belanglos, da ja die Zelle, welche die Abgrenzung der primitiven Blutbahn nach innen und aussen bildet, eigentlich die Fähigkeit der Produktion beider Arten besitzt, eine Fähigkeit, die auch zunächst noch ihre freien Abkömmlinge bewahren. ${ }^{53}$

In Bone Marrow:

Nach dieser auf genaue Detailbeschreibung und zahlreiche Abbildungen gestützten Auffassung entsteht also auch im Knochenmark das blutbildende Gewebe durch Differenzierung aus losgelösten Mesenchymezellen vom Charakter lileiner und grosser ungranulierter basophiler Leucocyten, die sich sowohl in der Richtung der roten Blutkörperchen, wie auch der weissen weiterdifferenzieren; noch ausgesprochener wie in der Leber erschient dabei der ganze Prozess als ein extravascularer Vorgang. ${ }^{54}$

In the Spleen:

So unbestimmt auch vorerst noch die Angaben über die Herkunft der Blutbildunsgzellen der Milz lauten, so schient mir es doch im höchsten Grade wahrscheintich, dass in der Milz wie in Leber und Kinochenmark die Entwickelung ausgeht von indifferenten basophilen grösscren und kleineren Zellen, die als abgenundete Mesenchymzellen oder Wanderzellen an Ort und Stelle sich bilden und sich dann zunächst sowohl in der Richtung der Erythrocyten wie der Leucocytenreihe (granulierte Leucocyten) differenzieren. Dieses erste Elemente, die 'primitive Milzzelle,' wäre also auch hier wieder die primitive Blutzelle bezw. der primitive Leucocyt oder Molliers Hämogonie. Die Umwandlung dieser Bildungszellen in die kleinen Lymphocytenformen im Gebiete der Malpighischen Körperchen setzt als besondere Gewebsdifferenzierung erst zu einen späteren Zeitpunkte ein; ich werde zeigen, warum das für die Gesamtauffassung der Lymphocytenfrage völlig gleichgültig ist. ${ }^{5.5}$

In Lymphnodes:

$$
\text { 52 Ibid, p. 188. } 53 \text { Ibid, p. 196. }{ }^{34} \text { Ibid, p. 199. } 55 \text { Ibid, p. } 201 .
$$


Aus allen diesen Angaben geht also hervor, dass die freien Elemente der Lymphknoten an Ort und Stelle entstehen und zwar wie überall aus abgerundeten und losgelösten Mesenchymzellen, die eine bestimmte Zeitlang auch hier die Fähigkeit haben, sich in der Richtung der roten und weissen Blutkörperchenreihe zu differenzieren.

In Connective Tissue:

Als wesentliches Resultat aller dieser Untersuchungen ergibt sich also, dass dem embryonalen Bindegewebe zunächst im weitesten Umfange die Fähigkeit zukommt, aus seinen Mesenchymzellen freie bewegliche Blutzellen zu bilden, die den Typus der primitiven Blutelemente aufweisen und sich anfänglich sowohl in der Richtung der Erythrocyten wie der Leucocyten differenzieren können. ${ }^{57}$

The doctrine of specificity has found its support in phenomena of growth, chiefly in the solid terminations of lymphatics which are observed in rather late periods of ontogeny, and the avoidance of these sprouts by mesenchyme cells in the tail of the tadpole. The former fact has been by implication projected into earlier stages of development, and into peripheral regions which are not accessible to the method of injection. The latter has been erected into a general principle of vascular development, in spite of facts of diametrically oppposite import, both in the frog (Goette, Marshall, Morgan, studnicka) and in other transparent embryos (Wenkenbach, Raffaele).

The theory of adaptation rests upon the observation of the transformation of mesenchyme cells into endothelium in a large number of forms at various periods of ontogeny, ascertained by a variety of methods and by observers with very different problems in view; second on the reversion of endothelium to mesenchyme (v. Szily, Huntington, Mall): and third, on the community of products and the permutability of endothelium, blood cells and mesenchyme (Maximow, Datntschakoff, Mollier, Weidenreich et al.).

The doctrine of the angioblast is so closely entwined with that of the specificity of endothelium that there is little promise in an attempt to consider it separately, especially as this conception of vasculogenesis loses its chief raison d'etre with the recognition of the plasticity (non-specificity) of endothelium. As presented

${ }^{56}$ Ibid, p. 203. 
by Minot ${ }^{58}$ the doctrine of the angioblast rests on two general propositions.

1. The early appearance of the angioblast and its possible entodermal origin:

Die vergleichende Embryologie lehrt uns, dass die ersten Gefässe gleichzeitig auf dem Dottersack entstehen. Sie bilden eine einheitliche Anlage, die wir dem Vorschlage von His folgend kurzweg Angioblast nennen. Es ist aber gleich hervorzuheben, dass mehrere Forscher, wie Maximow in seiner neuesten Schrift, Blutgefässe aus dem mesoderm des Embryo direkt entstehen lassen. In der Tat können wir die vollkommene frühzeitige Unhabängigkeit des Angioblastes von dem eigentlichen Mesoderm nur als höchst wahrscheinlich behaupten. Der Angioblast liegt ursprunglich unmittelbar auf dem Dotter und bildet ein Netzwerk, das fast so fort nach dem ersten Erscheinen der Anlage sich zu erkennen gibt. Das Mesoderm, sensu strictu, bildet eine zusammenhangende Schicht, die oberhalb der Gefässanlagen liegt, und nur in den Liicken des Gefässnetzes unmittelbar mit dem Dotter in Berührung kommt. Der Angioblast scheint, der grossen Mehrzahl der Angaben nach, bei allen Wirbeltieren sich direkt vom Dotter abzuspalten. Es ist also sehr schwer zu entscheiden, ob der Angioblast genetisch als dem mittleren Keimblatt gehörig oder als Abkömmling des Entoderms aufzufassen ist. Selbstverständlich gehen die Anschichten hieruber weit auseinander.

2. Its probable complete independence (specificity of endothelium).

Es bleibt aber die Tatsache, dass der Angioblast sehr frühzeitig sell)stständig wird, und däss er das erste Gewebe des Embryo ist, welches eine unzweifelhafte Differenzierung und scharfe Abgrenzung aufweist.

Der Angioblast behält aller Wahrscheinlichkeit nach zeitlebens seine vollstandige Unabhängigkeit. Mit anderen Worten, es ist wahrscheinlich, dass die Endothelien der Blutgefässe (und der Lymphgefüsse) und die Blutzellen in jedem Stadium sämtlich direkte Abkömmlinge des primitiven Angioblastes sind. Leider aber erlauben uns unsere gegenwirtigen Kenntnisie nicht, mit absoluter sieherheit rine Mtinung hierüber auszusprechen.

It will be seen that the extremely problematic nature of both of these postulates is perceived by Minot and that his view of the derivation of blood and endothelium from the angioblast is hardly to be reconciled with the results of the careful and thorough investigations summarized by Weidenreich. One may

${ }^{53}$ Keibel a. Mall. Handbuch d. Entwickgeschicht. d. Menschen, Bd. 2, p. 453. 
share Dr. Minot's regret that the early closure ('09) of his chapter on the blood prevented him from availing himself of the fundamentally important data of recent haematólogy, but it is more seriously to be deplored that such far-reaching doctrines as those of the angioblast and of specificity should have been promulgated upon a narrow factual basis in a text-book that is sure to fall into the hands of the inexperienced when, at the time of publication, ('12), so much evidence was at hand which would seem to invalidate these hypotheses.

The statement (vide supra) that the testimony of the majority of findings supports a direct origin of the angioblast from the rolk must not be taken to imply an entodermal origin, for in this sense it is not substantiated by the literature as a few citiations from the careful articles of Rückert and Mollier ${ }^{59}$ may serve to show.

Amphibia, Urodeles:

Trotz vieler Bemuhüngen habe ich auch nicht zu entscheiden vermocht, ob an der Lieferung dieser Gefässzellen fur das Dotterfässnetz (Fig. 692 gfz) ausser dem Mesoblast auch der Entoblast beteiligt ist. Ich glaube bestimmter nur sagen zukönnen, dass im Bereiche der epithelialen Splanchnopleura keine Gefässzellen vom Entoderm abgegeben werden, während viele Beobachtungen dafür sprechen, dass seitlich am Dotter dies vorkommt. ${ }^{60}$

Anura:

Bei Anuren ist folglich die Blutzellenbildung vom histogenetischen Standpunkte entschieden eine vorwiegend entodermale gegenüber der vorwiegend mesodermalen bei Urodelen. Will man, um diesen Unterschied zu beseitigen, die Annahme von Schwink gelten lassen, dass es sich bei Anuren um eine verspätete Ablösung von eigentlich mesodermalen Zellen vom Entoderm handelt, so ist nichts dagegen einzuwenden und es mag dieselbe für manchen vielleicht eine gewisse Beruhigung sein. ${ }^{0}$ ?

Cytostomata:

Durch diese lückenhafte Untersuchung einiger Entwickelungsstadien von Petromyzon sind wir doch zu dem Resultat gelangt, dass die Gefäss- und Blutbildung bei Cyclostomen in einfacherer Weise sich abspielt als bei Amphibien. Es kommt das vor allem darin zum Ausdruck, dass bei Cyclostomen die Aufgabe, Gefässe auf dem Dotter absugrenzen, fast ausschliesslich noch der dünnen einschichtigen Mesoblastlage selbst zufällt, da nur stellenweise vereinzelte Gefässzellen auf dem Dotter șichtbar werden.

to 1906, Hertwig's Handb. d. vergl. u. exp. Entwick. d. Wirbelth., Bd.1, Th. 1.

co Mollier, loc. cit., p. 1068.

61 Mollier, loc. cit., p. 1074. 
Die Fntstehung der Blutzellen ist aber abhängig von der Art und Weise der Mesodermbildung, so dass der alte Streit, ob das Blut aus dem Mesoderm oder dem Entoderm sich bildet, gar nich generell für die Wirbeltiere entschieden werden kann. ${ }^{62}$

Dipnoi:

Es ähnelt also die Entwicklung mehr den Urodelen als den Anuren, da der Mesoblast frühzeitig vom Dotter sich trennt und die Gefässanlagen zunächst also ein mesodermales Produkt sind. ${ }^{3}$

Selachians:

In welchem Umfang diese entodermale Gefässbildung stattfindet lasst sich nicht leicht abschätzen. Die Zahl der Sprossen an einer Keimscheibe ist eine mässige und an den verschiedenen Keimscheiben zudem wechselnde, aber andererseits zieht sich ihre Bildung über eine verhaltnismässig lange Entwickelungszeit hinaus. Fs ist auch diese Frage weniger von prinzipieller Bedeutung gegenuber der Konstatierung der Thatsache, dass überhaupt die mesodermalen Gefässanlagen von Torpedo sich durch entodermalen Nachschub ergänzen, eine Ansicht (Rückert 1887), die so allgemein bezweifelt worden ist, dass ich selbst mit einen gewissen Vorurteil gegen meine eigenen vor 18 Jahren angestellten Beobachtungen an eine erneunte Untersuchung des Gegenstandes herangetreten bin. ${ }^{61}$

IIan sieht hieraus, wie wenig IVert der viel diskutierten Frage ob der Meso- oder der Entoblast die Blutanlagen der Selachier liefert, zukommt. Es ist im Grunde nur Sache des Uebereinkommens welchen Namen man der betreffenden Zellenschicht geben will. Entscheidet man sich zu Lehrzwecken für eines der beiden Blätter so wird man dem mittleren den vorzug geben dürfen, weil ein Teil der Inseln im selbständigen Mesoblast auftritt und die übrigen in einer Schicht die bald darauf zum Mesoblast wird..$^{55}$

Teleosts:

Als Produkt des peripheren Mesoderme wäre der intermediären Zellmasse zunächst die Fähigkeit zuzusprechen, Gefäss- und Blutzellen liefern zu können, und es wäre eine derartige Differenzierung derselben zu erwarten. ${ }^{66}$

Es lasst sich zunächst also wohl auch die gefässbildende Kraft der intermediären Zellmasse als peripheres Mesoderm aufrecht erhalten, und es müssten diese Gefässe den Dottergefässen echter Meroblastier in der blutbildenden Zone verglichen werden. ${ }^{67}$

Reptilia:

Was die genetischen Bezichungen der Blutinseln zu den Keimblättern anlangt, so leiten alle neueren Forscher diese Gefassanlagen aus dem Mesoblast ab, wie dies zuerst Strahl für Lacerta gethan hat. Das ist im Grunde auch die Meinung von Mehnert für die Schildkröte und von

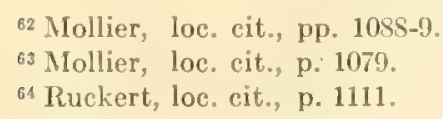

65 Ruckert, loc. cit., p. 1095.

66 Mollier, loc. cit., p. 1145.

67 Mollier, loc. cit., p. 1146. 
Völzkow fur das Krokodil, wenngleich beide Autoren den betreffenden Mesoblastabschnitt als Entoblast bezeichnet wissen wollen. ${ }^{68}$

Birds:

Fassen wir das Gesagte zusammen, so hat sich ergeben, das die soliden Anlagen der Dottergefässe des Huhnes ein verschiedenes Verhalten zum mittleren Keimblatt darbieten, je nachdem sie hinten oder vorn, aussen oder imnen in der A. vasculosa auftreten. Diese Differenzen lassen sich aber alle leicht verständlich machen, wenn man von dem allerersten Entwickelungszustand derselben ausgeht und zugleich das jeweilige Verhalten des in ihrem Bereich befindlichen Mesoblast mitberücksichtigt; Die Gefässanlagen der A. opaca bilden sich, sie mögen hinten oder vorn auftreten, als Verdichtungen und Verdichungen eines vom Keimwall sich delaminierenden Primitivstreifenmesoblast. Sie scheiden dann an ihrer Oberfläche eine Mesoblastdecke $a b$, wodurch die unterbrochene Kontinuitat des Blattes wiederhergestellt und sie selbst aus demselben ausgeschaltet werden. Die vorderen Anlagen unterscheiden sich von den hinteren genetisch darin, dass der Mesoblast sich von ihnen frühzeitiger differenziert und abtrent, weil er vorn viel rascher der Cölombildung zustrebt. Die zu innerst in der A. opaca befindlichen Anlagen differieren von den übrigen, weiter peripher gelegenen, darin, dass sie infolge ihres späteren Auftretens in einem Mesoblast sich bilden, der seine Verbindung mit dem Keimwall bereits gelöst hat. Sie erscheinen daher als rein mesodermale Bildungen. ${ }^{69}$

Mammals:

Nach dieser ausfürlichen Behandlung der peripheren Mesoblastbildung können die Vorgänge, welche direkt zur Herstellung des Blutes und der Gefässe auf dem Dottersack der Säugetiere führen, kürzer dargestellt werden um so mehr, als dieselben bisher nur von wenig Forschern genauer untersucht worden sind. Hier ist wieder an erster Stelle Kölliker (1875 u. 1879) zu nennen, der beim Kaninchen zu dem gleichen Befund einer mesodermalen Blutbildung gelangt ist, wie beim Huhn. Seine Angaben wurden durch Heape (1887) für den Maulwurf, Robinson (1892) für die $V$ aus, Janošik (1902) für Schwein und Ziesel, Fleischmann (1889) für die Katze und Kéeibel für das Meerschweinchen (1889) und den Menschen (1890) kurz bestätigt und vor allen in jüngster Zeit durch die ausfürlichen Darstellungen Van der Stricht's für da` Kaninchen (1895) und die Fledermaus (1899) erweitert. ${ }^{70}$

Eine Beteiligung des Entoblast bei der Blutbildung durch Abgabe vom Zellen, schliesst Van der Stricht sowohl fur das Kaninchen wie für die Fledermaus mit Entschiedenheit aus. ${ }^{7}$

An den gennanten Orten gehen beim Schaf nach Bonnet die Gefåsse aus vorgebildeten Räumen hervor, aus Lücken, die auf der Nabelblase zwischen dem Entoblast und dem visceralen Mesoblast, auf dem Amnios zwischen Entoblast und parietalem Mesoblast "ausgespart" und von den Mesoblastzellen allmählich "umscheidet" werden. Auf diese weise entstehen blutleere, d. h. erythrocytenfreie Endothelröhren. ${ }^{72}$

\footnotetext{
68 Ruckert, loc. cit., p. 1193.

7. Ruckert, p. 1253.

${ }^{69}$ IRuckert, loc. cit., p. 1219.

72 Ruckert, p. 1254.
}

${ }^{70}$ Ruckert, loc. cit., p. 1251. 
To return to $M$ Iinot 's eonception of an angioblast, his description of its formation permits a somewhat more definite examination of his position.

Turzgefasst findet die Differenzierung des Angiohlastes bei Amnioten folgendermassen statt: Er bildet ein Netzwerk, das anfänglich aus Zellsträngen besteht, diese werden bald hohl; nach vielen Beobachtern kann die Höhlung auf der unteren sicite zuerst nur vom echten Dotter begrenzt sein. Die Angioblastzellen bilden sich zum Teil in Endothelzellen, zum Teil in junge Blutzellen (Mesamöboïde) um. Das Endothel entsteht aus der peripherischen Lage der, tränge, die Blutelemente dagegen aus den mehr central gelegenen Zellen. Nur die Endothelien bilden ein ununterbrochenes Netz, die Blutzellen dagegen stellen zerstreute Haufen, die sogennten Blutinseln dar. ${ }^{73}$

In this passage a stratum is described interposed between the entoderm and the mesoderm (sensu strictu), which is evidently the Ciefiisblatt of many authors, a structure eminently rasculogenetic but not exclusively so as was accurately stated by Bonnet. ${ }^{74}$ Its non-vascular products have generally been lost sight of, but its proendothelial stage is clearly recognized by Felix:75

Die Darmarterien des Menschen entwickeln sich aus einem Gefässnetz, welches Darm-und Dottersack umspinnt (rete periintestinale). Fig. 539 zeigt die Rekonstruktion der Gefässe eines Embryo mit 5 bis 6 Ursegmentpaaren. Die Aorta ist bis zum zweiten Ursegment als Rohr mit allseitig geschlossener Wandung entwickelt, von da $a b$ caudalwärts ist sie erst in der Anlage begriffen; sie erscheint hier auf dem querschnitt bald als geschlossener Ring, bald aus vereinzelten Zellen bestehend. Vom zukünftigen 7. Ursegment bis zur Schwanzspitze ist zwischen Dottersack bzw. Enddarm einerseits und visceralem Mesoblast anderseits ein Gefässnetz eingeschaltet, das rete periintestinale (Fig. 521 und 450). Im Bereiche des Mitteldarms sind die Matschen dieses Netzes schon mit deutlicher Wand versehen (dunkelrot in Fig. 539), im Bereiche des Enddarms haben wir noch gar keine Maschen, sondern nur ein einfaches Gefässblatt (Fig. 540), welches durch Delamination von dem visceralen Mesoblast abgelöst wird und noch keine einzelen Gefässe entwickelt hat (blass rot in Fig. 539); in ihm verliert sich die aorta (Fig. 539). Aus diesem Gefässblatt entstehen also rete periintestinale und aorta.

73 loc. cit., 481.

"1859, Arch. f. Anat. u. Entwickelungsgesch. p. 1.

75 1912, Keibel and Mall Handb. d. Entwickschich. d. Mensch.

Bd. 2, pp. $757-8$. 
More recently Bremer ${ }^{76}$ has reconstructed what is essentially a prevascular stage of this layer.

I would emphasize the early stage and the cells which do not become endothelium, because I believe that in them we find an exit from the embarrasment of recognizing an independent angioblast which yet in its products is identical with mesenchyme, for we have too little evidence of convergence in ontogeny to make the idea of such an assimilation a prioriattractive. It would seem, therefore, simpler to accept an origin of mesenchyme in the splanchno-pleure at an earlier period than has been universally recognized, by a migration of elements from the germ layers into the mesostroma as has been described by $v$. Szily, ${ }^{77}$ Studnička ${ }^{74}$ and others. The peculiarity of this district would then consist in its great degree of vascular productivity which might be occasioned physiologically by its relation to the yolk, ${ }^{79}$ rather than determined genetically by a hypothetical derivation from the entoderm. We here approach the standpoint of Raffaele ${ }^{80}$ "le cellule endothetiali provengono dal mesenchime"-and are encouraged to hope that eventually the formally genetic views embodied in the doctrine of the angioblast will give way to a more biological standpoint of interpretation, viz., that endothelium is the result of mechanical, blood of biochemical factors, both consequent on position in the broad sense of the term, and are neither of them rigidly predetermined to a special cytomorphosis by obscure causes associated with a peculiar provenience of their elements.

The mesenchyme has long been held to be a complex of variously derived elements, which owe their resemblance and solidarity to a common position, not to likeness of origin. That cells free themselves from germ-layers and migrate into the mesostroma between them is well established, and that ressels make an early appearance in these strata is indisputable, in the somato-pleure as well as in the splanchno-pleure. But that in the latter situ-

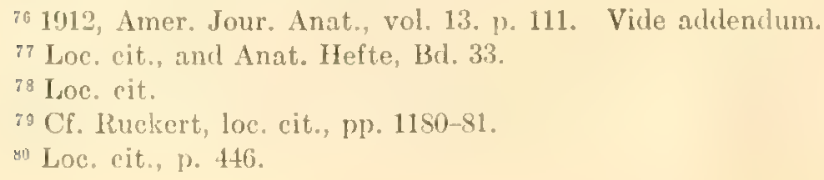


ation we have two independent subsidiary germ layers, mesenchyme and angioblast. which are absolutely distinct, though inseparably united, and are in no sense phases or modifications of one structural basis, is not an obvious conclusion and is insuperably difficult in the riew of the later permutability of endothelium and mesenchymal derivatives.

The entodermal origin of some of these elements, the mesodermal of others, the great proportional variation of the two components in different ova, would seem to point to position in the broad sense of the term, and not to derivation as the determining factor in their behavior. The comprehensive and detailed resumé of Rückert and Mollier, together with their individual contributions seem to necessitate a view of this sort, for they definitively dispose of an entodermal or a mesodermal origin of vessels as a general principle of vasculogenesis.

Clearly therefore, though the causative factors of vasculogenesis in the blastoderm are but imperfectly understood, yet in the light of present knowledge the soure of the vasofactive cells must be conceived as of secondary rather than of primary importance. The doctrine of the angioblast can therefore find no support in the facts of comparative embryology in so far asit hints an entodermic origin for endothelium and blood. But if angioblast and mesenchyme are thus conterminous, arising from the same sources, and possesing like potentialities, and have further the most intimate topographical relations, it is difficult to see how they have come to be separated conceptually by some investigators, unless it be from their too intensive confinement of attention to the splanchnopleure, were the excess and precocity of rasculogenesis somewhat masks the presence of mesenchyme.

This is the phase of the problem which I have endeavored to approach directly in the light of observations upon a series of blastoderms of the domestic cat, ranging from the period of the three-layered blastoderm, to the stage of fourteen somites. They were fixed in 'Zenker's solution, embedded in paraffin, cut into serial transverse sections $13 \frac{1}{3} \mu$ thick, and variously stainedthe most satisfactory results on the whole being gained with 
Delafield's haematoxylin and eosin, or Heidenhain's haematoxylin. Reconstructions were made by the Born method in four cases; for others, in small easily defined areas, where conditions were simple, the quicker but less satisfactory graphic method was employed.

For convenience of analysis, the data are presented under two headings:

1. The early formation of vessels beneath the ectoderm, with special reference to the umbilical vein.

2. The early formation of vessels above the entoderm, especially the omphalo-mesenteric plexus and the aorta.

\section{THE UMBILICAL VEIN}

The early stages in the development of this vessel afford an opportunity to study the formation of endothelium in a circumscribed region and under comparatively simple conditions. It appears first near the lateral margin of the incipient intraembryonic coelom and is separated from the entoderm by the whole thickness of the as yet imperfectly cleft mesoderm. The inner germ layer patently is excluded from direet participation in the formation of this endothelium, and its appearance, antedating the establishment of continuity with any derivative of the splanchno-pleuric plexus, must entail the acceptance of its origin in situ. I am not aware that the independence of the umbilical vein and the associated hypectodermal vessels has ever been impugned. It was recognized by His and more recently has been considered by Mollier. In the cat it retains its isolation to the stage of 14 somites. It would seem, however, that it: importance from the theoretical standpoint has not been universally appreciated. The position of the umbilical vein at the amnio-embryonic angle suggests that the vascular potentialities of intra-and extra-embryonic portions of the germ layers are not, of necessity, totally disparate. The extent of the vessel, its comprehensive drainage area, its high physiologieal importance, seem to require that its mode of formation be respected in general interpretations of vascular development. A doctrine such as that of the origin of endothelium from entoderm, or by the growthof of anlages formed in the splanchnopleure alone, neg- 
lects the case of the umbilical rein, and is to that large degree incomplete and partial.

The youngest embryo which requires consideration here is No. 550 of the Columbia Collection. The somites are forming but as yet there is no complete intersomitic cleft; the coelom is little more than a line of beginning cleavage; in a few places the layers of mesoderm separate and narrow discontinuous clefts appear.

The parietal mesoderm is, in general, compact. It is separated from the ectoderm by a space which must be considered in large part due to shrinkage. In general, the outline of the mesoderm is clear cut, but lateral to the neural plate and dorsal to the coelom-clefts short protoplasmic processes extend from its peripheral cells into the hypectodermal space; a few are also to be seen on the basal surface of the ectoderm. These are evidently the fibers of Aurel v. Szily, s1 the interdermal cytodesmata of Studnicka, ${ }^{\text {s2 }}$ which collectively constitute the mesostroma of the latter investigator. Subsequently, these processes form a felt work hetween ectoderm and mesoderm, into which cells from the mesoderm migrate. The latter process, the formation of the somatopleuric mesenchyme, is in its inception in this embryo. We may distinguish first a loosening of the cells of the meroderm characterized by an increased distance between the nuclei, the appearance of intercellular clefts, and the projection of an occasional nucleus beyond its fellows; second, the appearance of cells, or more strictly energids, connected by broad protoplasmic bridges with the mesodem; in some cases the bridges are narror, the energids are distinctly pedunculated, and finally there are a very few elements which are joined to the mesoderm by tenuous cytodesmata only.

In embryos in which the first intersomitic cleft is complete (Columbia Collection Nos. 449. 554, 555) the mesenchyme has increased in amount and the area involved is larger, now extending mesad along the parietal mesoderm as far as the somites (fig. 1). The mesostroma is more abundant and in places forms a feltwork of protoplasmic strands. The dorsal contour of the

\footnotetext{
81 1903, Anat. Anz., Bd., 24, p. 417.
}

82 1911, Anat. Aaz. Bd. 40, p. 33. 
mesoderm is irregular: many of its elements project into the hypectodermal space, some broadly, some, narrowly pedunculate, others connected to the underlying mesoderm only by fine cytodesmata. The cytoplasm of these energids' is very scanty; the nuclei are large, vesicular, with one or sometimes a second, large spherical karyosome. In view of their scanty cytoplasm and the protoplasmic nature of the mesostroma there is no serious error in describing the process as a wandering of the nuclei, as Mall ${ }^{83}$ does in the case of a similar phenomenon in the endocardium. In both cases mesenchyme is forming, here from mesoderm, there from endothelium; the latter therefore has not with its rhange of form lost the potentialities of mesoderm in this respect.

An embryo ${ }^{84}$ (Columbia Collection No. 539), in which two complete intersomitic clefts are present shows a marked increase in the hypectodermal mesenchyme. Its distribution is shown in figures 2 to 4 . In this case as in the following models, the compact mesoderm is reconstructed in white, in contradistinetion to the mesenchyme which is green. The surface appears more uniform than is actually the case, for it was found impossible to retain the innumerable small strands of mesostroma and all the minute projections and irregularities that characterize the contour of the mesoderm in section (fig. 5). The model, therefore, shows only the topography of the mesenchyme. This is most abundant in the head region where the axial mesoderm is less compact than elsewhere, and along the lateral margin of the coelom in the plane of the somites and for some distance caudad. To a less degree, mesenchyme has formed from the parietal mesoderm and the dorsum of the somites.

In section, the somites have regular contours, but elsewhere the mesoderm gives rise to innumerable strands of mesostroma joining it to ectoderm. The mesenchyme elements have increased, and in addition to individually projecting cells, which show every degree of emergence from the mesoderm, larger processes of this layer extend into the hypectodermal space. These

83 1912, Amer. Jour. Anat, vol. 13, p. 249.

${ }^{84}$ I desire to cxpress my appreciation and thanks to Prof. J. H. McGregor for the gift of this beautifully preserved cmbryo. 
changes are at a maximum along the lateral margin of the coelom where the parietal as well as the visceral layers are fairly resolving themselves into mesenchyme, to an extent that threatens to interrupt their continuity - a conformation which characterizes this region until the coelom is fully formed. In individual sections there are many cells which appear free of the mesoderm save for cytodesmata. The study of serial sections shows that many of these are actually free (save for cytodesmata), but that others are the tips of the processes of mesoderm just mentioned. While the mesenchyme continues to be recruited by the migration of single cells, from this period on there occurs a more intensive process, in which projections are formed and separate en masse, and as these projections are inclined to the mesoderm at an acute angle and often extend through several sections, this phase of mesenchyme production may be described as delamination.

In the embryo of four somites (Columbia Collection No. 409) there is an interval between the mesenchyme of the lateral sheet, and that in the head and in the region of the nephrotomes, occasioned by the relative unproductiveness of the parietal layer of the cardiac coelom, which is thin and compact. The two areas become continuous opposite the last somite (fig. 6).

Our next embryo is of eight somites (Columbia Collection No. 530). The two areas of mesenchyme are now closer together and the parietal layer of the cardiac coelom is active in the production of this tissue (fig. 7).

In both of these embryos we find the same intimate relation between mesoderm and mesenchyme that has been described.

There are evidences of active migration of single energids into the mesostroma assisted by a coarser process of delamination. In addition, there are evidences of the inception of endothelium. Small clefts or cavities have appeared here and there amid the cells of the mesenchyme, which are thus roming to enclose minute vesicles. As these cells are in a syncytium, the question of the locality of the cleft, whether inter or intra-cellular is of secondary importance. The situation of these incipient vesicles (rasofactive cells) is indicated by the yellow color in figure 7 . 
In figures 8 and 9 are shown sections of a vesicle in relation to the second nephrotome of the four somite embryo, which it will be seen has some superficial resemblance to a pronephric anlage. There is also a smaller one opposite the incipient fifth somite and a solid mass opposite the first somite. In the eight somite embryo, there is a similar sac-like anlage at the interval between the first and second somites; elsewhere along the nephrotomes are scattered mesenchyme cells. The formation of clefts has also been initiated in the lateral portion of the mesenchyme at several points.

The comparison between these embryos does not suffice to give a local individuality to the several endothelial anlages, it merely shows the inception of the latter tissue diffusely from mesenchyme. In older embryos the condition is found repeatedly and appears to be an intermediate stage between mesenchyme and endothelium, as it certainly is intermediate in form between the mesenchyme mass and the endothelial sacs; these cells of intermediate form are here designated vasofactive.

In the umbilical line, the formation of endothelium is accelerated cephalad; almost none is found caudal of the fifth somite in the ten somite embryo (Columbia Collection No. 532). Its distribution is shown in figure 10. There is abundant mesenchyme in the hypectodermal space as far caudad as the third somite. In its midst, but tending to a deep position near its junction with the compact mesoderm, are groups of cells with more abundant protoplasm which stains a little faintly. They form small masses, in intimate syncytial comnection with the ordinary mesenchyme. In their interior are frequently small clefts. In some, the cavity is larger and the enclosing cells are flattened, eventually becoming thin and endothelioid (fig. 11). These last we may call angiocysts, using Bremer's term. 'The presence of several minute clefts or vacuoles in a single mass of vasofactive cells, suggests their formation by the running together of these small cavities. In figure 10 the ordinary mesenchyme is omitted, the clefts and cavities are shown in red, the protoplasm of their bounding cells in black. Opposite the fourth and fifth somites are scattered cells and cell-groups of a similar appearance in which cavities have not yet appeared. These are readily dis- 
tinguished from the other mesenchyme cells by their transverse position, in addition to their slightly more abundant protoplasm and slightly paler stain. It is possible that the latter two characteristics may be due to the imbibition of fluid. The anlages of the unbilical line are disposed along the lateral margin of the coelom. A mesal line of similar anlages is forming above the nephrotomes, while a few scattered elements have an intermediate position. In all these situations the process is discontinuous, the misises of rasofactire cells as well as the cavities are separated by appreciahle intervals in which ordinary mesenchyme is present. They can be made into a continum only by the inclusion of this tissue. The result would be a sheet of mesenchyme studded with scattered endothelial anlages as in the model of the twelve somite embryo (figs. 12, 13).

A second embryo of twelve somites (Columbia Collection No. 540 ) is shown in figure 14 for comparison with the embryo just described. The discontinuity of the anlages is again apparent. In addition to those before mentioned in the umbilical line, in the cardinal line (along the nephrotomes) and intermediate between the two (somato-pleuric plexus), an angiocyst has formed just in front of the first somite. The transverse vasofactive cells have increased in number and are effecting junctions with one another and with the angiocysts. In a third embryo of 12 (Columbia ('ollection No. 536) somites, there were rather more numerous vasofactive cells, rather less developed endothelium but the general arrangement was very similar; the angiocyst in front of the first somite was also present.

The transverse position of the vasofactive cells requires explanation. They stand out clearly against the other mesenchyme cells which have their long axis in general ratial, and are further distinguished by their rather deep position, near or in the almost cell-free interval between the bulk of the mesenchyme and the compact layer of parietal mesoderm. The nephrotomes are now resolving rapidly into mesenchyme, they are segmented, and are separating from the coelomic mesolem; through the spaces thus formed, which contain only a loose mesostroma, the hypectodermal and hyperentodermal regions communicate. In the latter 
the aorta, in the former the umbilical angiocysts are enlarging. The distending fluid must be derived from the adjacent region and its determination to these reservoirs must set up currents in the neighborhood. It is suggested that the conformation of the region (fig. 15) is favorable to the direction of such a current along the dorsal surface of the lateral mesoderm in the narrow interval between it and the bulk of the somatopleuric mesenchyme and that to this current the vasofactive cells owe their transverse orientation. Mesal to the coelom where the nephrotomes are resolving and where the current, if there be one, is directed ventro-mesad towards the aorta, the vasofactive cells have an oblique position. I have already referred to Bartels' view that the addition of cells to the tips of lymphaties is occasioned by currents; it would be satisfactory to think the same principles at work in both late and early stages of vascular formation and to find that the current, the sine qua non of the persistence of endothelium, is also its determining cause.

The vasofactive cells are dorso-ventrally flattened, they occur singly, in groups of two or three, continuous with, or wholly separate from the angiocysts. Where joined to the latter they could of course, in section be taken for sprouts, in spite of their flat plate-like form. But if more caudal regions of the same embryo are examined, or a corresponding region in a younger embryo, isolated flattened cells are found constantly, which I take to be evidence that the continuous plates, or if you will, cords are built up by the accretion of separate cells. When it is borne in mind that the distance from the umbilical to the cardinal line can be spanned by a half dozen of these cells, the opportunity of finding the angioeysts of these lines, continuous by means of strands of 'angioblast,' is not wanting. In one case (an embryo of $\mathbf{1 6}$ somites, Columbia Collection No. 551) I found such a cord extending from the umbilical vein to the aorta, which could have been taken to prove the origin of the aorta from the umbilical vein or vice versa by one who was apt at interpretation and had refrained from examining earlier stages.

In the 14 somite embryo (Columbia Collection No. 188) the umbilical vein has become organized in its whole length; there 
are scattered but not very numerous anlages in the cardinal line, and in the interval between the two. Nany in the last position are now coalescing with the umbilical vein, which is assuming its function as a somatopleuric drainage channel. Caudally it turns dorsad in the wall of the amnio-embryonic cavity and terminates among vasofactive cell-masses. Conditions opposite the first somites are shown in figure 16 . The dilated cephalic extremity of the umbilical vein shows evidence of its origin by coalescence in the presence of several perforations and septa. At the level of the third somite it has effected a connection with the omphalo-mesenteric vein which crosses it ventrad at right angles. The intervening compact mesoderm lateral to the coelom has given way over a small area (fig. 17) through which the anastomosis between the reins is established. Near the cephalic margin of the third somite a transverse vessel is forming and is continued forward obliquely to the front of the first somite where it is continuous with the channel along the neural tube. A comparison of these vessels with the angiocysts of figures 10 and 14 makes evident their correspondence in position. There is further a small communication between the transverse vessel and a branch of the aorta. Several small and as yet unannexed vesicles are present.

The whole length of the umbilical line in a twelve somite embryo (Columbia Collection No. 547) is shown in figures 12 and 13. The somatopleuric mesenchyme is seen from below, the mesnderm haring been omitted as far mesad as the nephrotomes. Cephalad the vein is represented by a large multilocular cyst which extends from the limb bud, in which is a blood island, to the level of the fifth somite. Then follow a series of angiocysts, which are coalescing opposite the sixth and seventh somites but farther caudad are scattered and often widely separated. Vasofactive cells amid which clefts have appeared are shown in yellow. There are numerous discrete vesicles in the cardinal line, which being dorsal to the nephrotomes are not well seen in the figure. Opposite the last somites the mesenchyme forms a network of cords, the solidity of which is necessarily exaggerated by the reconstruction. The resemblance to Bremer's angioblast cords is striking. 
Caudad the anlages of the umbilical line are in the wall of the amnio-embryonic cavity (figure 18). The amnionic position of vascular rudiments has been described by Bonnet, Spee, and Keibel. ${ }^{85}$ Although the position of the umbilical in the cat is really at the amnio-embryonic junction, and appears to be unusual only because of the moderate entypy of the blastoderm and the early closure of the amnion caudad, there are in addition endothelial sacs actually in the amnion itself as may be seen in figure 19 from a 16 somite embryo.

The foregoing data seem fully to warrant the conclusions that endothelium is formed directly from mesenchyme in the somatopleure and that ressels result from the concrescence of discrete anlages. With these facts in mind we may approach the more difficult region of the splanchnopleure.

\section{THE EARLY FORMATION OF VESSELS ABOVE THE ENTODERM}

The formation of mesenchyme and endothelium in the splanchnopleure is essentially the same process as in the somatopleure; the differences are mainly in the proportions of the two tissues for here endothelium predominates and is associated with the extresive production of blood cells. In brief, there is a separation of cells from the mesoderm, by individual migration and extensively in groups and masses; the elements are interposed hetween the entoderm and the compact mesoderm, that is they come to occupy and finally obliterate the hyperentodermal space. The major part give rise to endothelium, and in the case of the larger masses (blood islands) to blood cells. Of the remainder, a considerable proportion subsequently become endothelium, but there is always a residum of mesenchyme present. Later this becomes conspicuous and surrounds and embeds the vessels.

The process is initiated by the formation of blood islands. These appear as spindle shaped discrete thickenings of the mesoderm at a considerable distance lateral and eaudal to the embryonic axis, in regions where the mesoderm is free and separated by an interval, probably much increased by fixation, from the entoderm.

${ }^{85}$ Quoted from Ruckert, loc. cit., pp. 1253-4. 
The thickenings soon come to project from the rentral surface of the mesoderm, and begin to separate from it. At about the time when the first somites are forming and before definite intersomitic clefts have appeared, the migration of energids becomes extensive and desquamation is also well marked. The uncleft mesoderm, the risceral layer of the incipient coelom, and the intermediate cell mass are all affected (fig. 20). Many strands of mesostroma cross the hyperentodermal space and among these the mesenchyme cells are scattered, singly or in flat plate-like groups. They show every degree of connection with the compact mesoderm, the plates in particular being often broadly connected. It is a repetition on a larger scale of the processes observed in the somatopleure, earlier in time, and more active. As yet no endothelium or blood cells have been formed.

In the model of the embryo of two somites (figs. 21 to 23) the distribution of the tissue in the hyperentodermal space is shown in relation to the compact mesoderm (white) - the mesenchyme is green, endothelium red, and the intermediate forms of tissue (vasofactive cells) yellow. Cephalad the line of the heart, ventral aorta and first arch is occupied by scattered mesen hyme cells and cell groups. There are also a few isolated mesenchyme elements of more mesal position. The line of the aorta is vacant to within a short distance of the first somite. Here scattered cells and plates are present. Ventral to the somites and immediately caudal to them an irregular continuous plate or strand has appeared. As yet this is connected with the more lateral mesenchyme in which the omphalomesenterie plexus is forming only at one point. There are, however, numerous patches of mesenchyme scattered in the interval. Caudad in the region of the primitive streak there is no axial mesenchyme. There is much mesenchyme, associated with vasofactive cells and endothelium, along the lateral margin of the coelom and extending mesad below the visceral mesoderm. This is most abundant caudad of the heart and the transterse plane of the somites, approximately in the region which Schwink regarded as the point from which endothelium sprouts.

${ }^{86} 1891$, Morph. Jahr., Bd. 17, p. 288. 
The embryo of four somites (fig. 24) shows a very considerable advance beyond this condition and illustrates the rapidity, almost abruptness, of the changes in rasculogenesis which have been described by Huntington. ${ }^{87}$ The heart which is now concealed in the myocardium is composed of a series of endothelial vesicles the walls of which are in contact and are often connected with processes of the mesoderm. In general structure it is not dissimilar to the segment of the omphalomesenteric vein with which it is continuous caudad. Cephalad the line of the ventral aorta is represented by plates of mesenchyme, vasofactive cells, and small endothelial sacs. A large multilocular cyst, showing evidences of concrescence in its septa, forms the cephalic element of the dorsal aorta. Laterad it is connected with the first arch which is already endothelial, and a similar connection is established with the juxta-neural line, i.e., the angiocysts are in contact, but their lumina are still divided by numerous delicate septa (fig. 25). A second endothelial sac in the aortic line is situated just cephalad of the somites, ending near the first somite in continuity with a flattened plate of mesenchyme cells.

Corresponding to the other somites are plates of mesenchyme, vasofactive cell masses with cleft-like lumina, and a few angiocysts. The omphalomesenteric plexus is composed of larger vesicles which are now coalescing, but their lumina are not as yet continuous with either the heart or the aorta. Between the mesal rasculogenetic line (the dorsal aorta) and the lateral, which comprises the ventral aorta, the heart and the omphalomesenteric vein and plexus, are scattered mesenchyme and vasofactive cells; cephalad these are more abundant and are now coalescing to bridge the interval between the dorsal and the ventral aorta. The first arch is endothelial and situated somewhat in front of the point at which connection is established with the juxta-neural line. Two other transverse strands are present, one largely mesenchyme, one of vasofactive cells.

8: Developmental relations between Iymphatic amd haemal vascular channels. Paper read at the XVII Internat. Med. Congress. London, August, 1913. To be published in the Am. Jour. Anat. 
In the embryo of eight somites (fig. 26) a moderate adrance has been made in organization and considerable changes in topography have been effected. The most striking at first glance is the increase in the internal limiting sulcus incident to the formation of the foregut. But it will also be observed that the heart has been carried forward and is now much nearer the blind extremity of the foregut than in the four somite embryo. The first somite is also at a position cephalad to that of the younger embryo. This might be taken to inply an addition of somites at the cranial end of the series, a most difficult point to establish in the absence of fixed landmarks and in the shifting topography of this regiom. But this assumption would not explain the advance of the heart. The increase of the mesoderm dorsad, and the formation of the foregut seem to call for a rearrangement of this layer and may possibly account for the shortening actually observed, though this naturally does not exclude the possibility of the production of somites from the head mesoderm.

The aortic angiocysts are confluent from the first arch to the fourth somite, and mesal to them are mesenchyme cells, many but not all of which are adherent to their walls. The heart is multilocular. The omphalomesenteric vein now has a continuous lumen and has effected several small connections with the omphalomesenteric plexus, which is now extensive. Amid its channels are scattered mesenchyme and vasofactive cells and numerous projections from the mesoderm, the tips of which on reaching the entoderm spread out, form horizontal processes, and partially enclose the endothelial channels (fig. 27). Subsequently these projections are resolved into mesenchyme in which the vessels are imbedded.

In the embryo of twelve somites (Columbia Collection No. 547 ) the dorsal aorta has acquired a continuous lumen from the first arch to the region of the primitive streak. Caudad it diminishes in diameter and terminates in connection with scattered angiocysts and vasofactive cells, which farther caudad give place to mesenchyme (fig. 13). The first arch is double, one arm passing laterad, one cephalad to the lateral cul de sac of the foregut. The ventral aorta is endothelial and at the sides of the gut is 
connected with plates and strands of mesenchyme, which are the presumptive anlages of the aortic arches and the adjacent mesenchyme. Amidst this tissue are a few blood islands.

The precise source of the cells which form the endothelium of the aorta is somewhat difficult to determine. The clear cut contour of the somites until the formation of the sclerotomes makes it difficult to believe that cells are here given off to the mesenchyme. Mollier has held that its material is derived from the intermediate cell masses, and has showi sections in which they are connected to the aorta by solid processes, similar to those which elsewhere give rise to mesenchyme and endothelium.

Such connections also are found in the cat. At the stage of eight somites, and more clearly in that of twelve (figs. 12 and 13) the aorta becomes joined to a more lateral point of the visceral mesoderm. From the convexity which this layer forms below the coelomic angle a ridge of cells projects ventro-mesad. This is separated in many places from the mesoderm sensu strictu by a narrow cleft, and thereupon comes into apposition with the aorta(figs. 29 to 33 ); in places the cells of this ridge become endothelial and contain a lumen which eventually communicates with that of the aorta. It is posssible that the connection with the intermediate cell mass described by Mollier may be of a similar nature, and that in both cases we are dealing with an increment to already formed endothelium. The anlages of the aorta both in front and hehind the somites are freely connected with the orerlying paraxial mesoderm and it is probable that they are directly derived from it prior to its segmentation. Later when the sclerotomes are formed the aorta enters into intimate relation to their loosely arranged cells (figs. 29 to 33). The addition of elements from this source to the aortic endothelium has been described by Mollier, ${ }^{88}$ and his results are abundantly confirmed by conditions in the cat. Some of these cell masses acquire a lumen before addition to the aorta. In other sections the vessel loses its well defined outline mesad and its wall is completed by typical mesenchyme, with the interstices of which its lumen com-

${ }^{8}$ Loc. cit., p. 1267. 
municates. Finally the mesal angle of the aorta is often occupied by masses of adherent bood cells, as though the sclerotome had given rise not only to endothelium but blood cells as well.

To summarize: the formation of endothelium in the splanchnopleure is precisely andogous to that in the somatopleure. Mesenchyme is formed in situ and secondarily in large part is transformed into endothelium. There are few solid strands of mesenchyme ('angioblast') and these are not primary but arise from the concrescence of scattered plates of mesenchyme. They are rarely transverse, as though they had grown in, but conform to the lines of future vessels. More important than their frequent interruptions as evidence of in situ origin, are their innumerable connections with the compact mesoderm, every degree of emergence from which, both by migration of single energids and by delamination, is conspicuous in every embryo examined.

\section{ADDENDUM}

Since the foregoing paper has been in proof a communication made by Bremer at the thirtieth session of the A.A.A. in Philadelphia and published in abstract (Proc. Am. Ass. Anat., Anat. Rec., vol. 8, no. 2) makes a brief consideration of the results of this investigator desirable. In his first paper (Am. Jour. Anat., vol. 13, 1912) Bremer describes the development of the intraembryonic blood vessels in the rabbit as resulting from the ingrowth of a continuous network of "angioblast cords" derived from the extraembryonic plexus of the yolk-sac. Although dealing in this paper with the development as found in rabbit embryos he examined other species, as chick, pig, sheep, etc., and felt "satisfied that in all essential points the story of the development of these primary vessels in other vertebrates will be found similar. . . . " The evidence on which these conclusions rest is briefly the continuity of the aortic and cardiac angiocysts with the extraembryonic vessels of the splanchnopleure by solid cords of cells, which are interpreted as angioblast. The essential data are given succinetly and the principle of his interpretation made clear in the description and figure of the rabbit embryo of 5 segments. "Fig. 1. a reconstruction of the angioblast cords of one side of a rabbit embryo of five segments, shows these cords, streaming in from the network over the yolk-sac. . . . They have grown from left to right of the figure, occasionally anastomosing until near the median line, which lies at the left of the figure. The shape of the meshes of this net indicates it seems to me the direction of this growth and the rapidity with which it has occurred." I question both the angioblastic nature 
of these cords and the principle on which they are interpreted as ingrowths. Continuity of structure at a given period of development can not be held to establish the presence of continuity at earlier stages, for it may be secondarily achieved, as is shown by the union of the mesonephroic tubules with the pronephric duct, to instance but one of several similar junctions in the development of the genito-urinary tract. In this particular case I must consider both the assumption of primitive continuity and of ingrowth wholly invalidated by the experiments of Hahn (Arch. f. Entw. Mech. I Organismen Bd. 27, 1909) and the recent very satisfactory confirmatory results of Miller and $\mathrm{Mc}$ Whorter, which after some amusing editorial adventures in the office of the American Journal of Anatomy were presented at the thirtieth session of the A.A.A. (Proc. Am. Ass. Anat., Anat. Rec., vol. 8 , no. 2, p. 91). As to the nature of the cellular cords designated angioblast, it is to be noted that Bremer does not figure or deseribe either mesostroma or mesenchyme in his embryos. As he does not distinguish these formations, it is possible that they are included in his angioblast cords, which would then represent an early for the most part prevaseular stage of the splanchnopleuric mesenchyme. I am inclined further to this view by the loss of cords in the embryo of 6 to 7 segments as evidenced in the comparison of figures 1 and 3 , and to which Bremer calls attention in his text. The most plausible explanation would be that they had resolved themselves into mesenchyme; that therefore the primitive network was mesenchyme, which in widely separated regions was partially transforming itself into endothelium.

I am interested to note that in his second paper, a highly interesting study of early vessels in man (Proc. Am. Ass. Anat. 30th Sess. Anat. Rec., vol. 8, no. 2, p. 97) Bremer abandons his original position and accepts the development of discontinuous vascular anlages independent of the vessels of the yolk-sac, but nevertheless retains the principle of growth in continuity in the vascularization of the embryonic body. With the general principles of blood vessel origin from mesoderm I am in hearty agreement, as also with the multiplicity of anlages, and their intimate relation to the coelomic mesoderm. In these points there now seems to be a very general agreement between the students of mammalian vasculogenesis. But I must question the validity of a continuous angioblast network "composed of angiocysts and solid cords," which appears superfluous in view of Bremer's conclusion that vessels "originate from ingrowths of mesothelium as a number of separated cords, angiocysts, or blood islands, which are soon connected by sprouts of endothelium." In the interpretation of the solid strands connecting angiocysts as 'angioblast' Bremer states that he relies on his earlier work upon the rabbit, and I would again express my dissent. The mesenchyme and mesostroma form a protoplasmic continuum in which are contained angiocysts. To designate such portions of it as intervene between two angiocysts "angioblast" is in my opinion to make a distinction which does not exist, and which would not suggest itself in regions where the mesenchyme preponderates over the blood vessels as in the somatopleure. 
PLATES AND FIGURES 


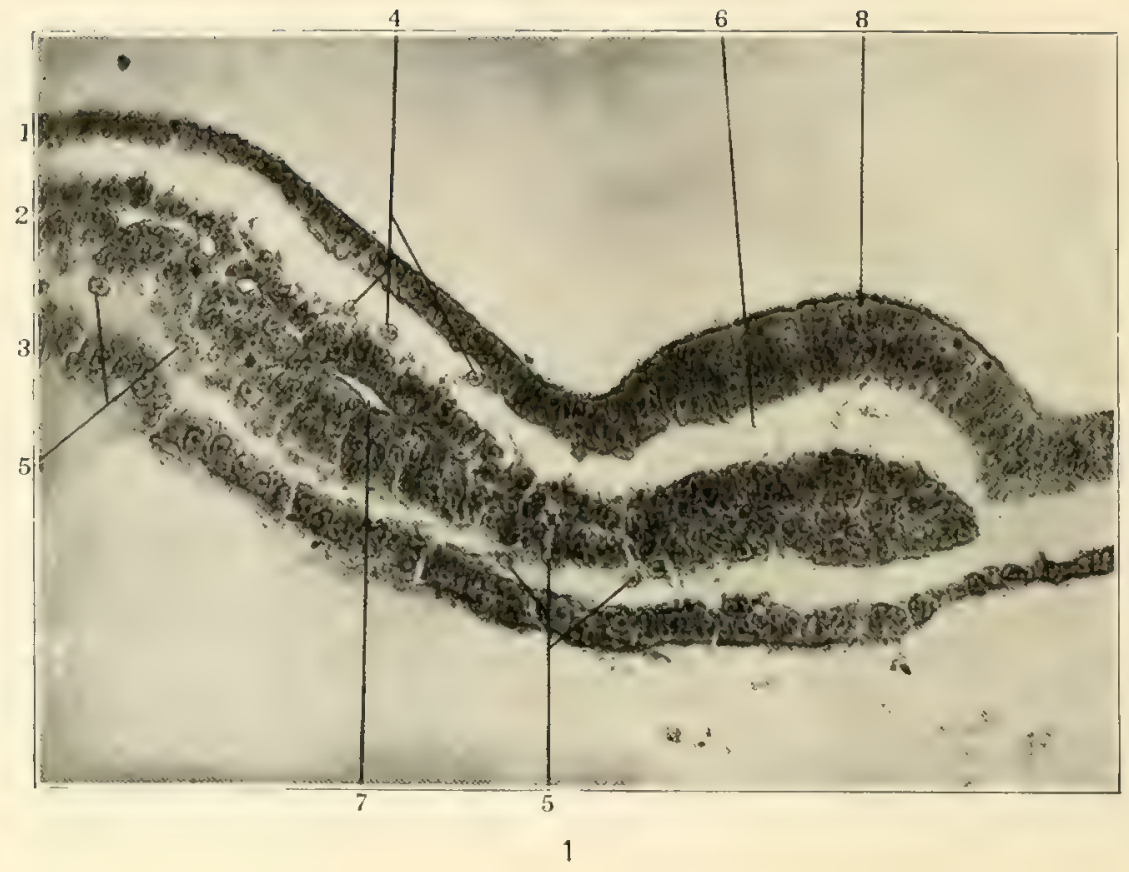

Fig. 1 Transverse section of an embryo with one pair of intersomitic clefts. Columbia collection No. 554, slide 4, row 5, section $8, \times 300$. Reduced $\frac{1}{4}$.

1 Ectoderm

2 Mesoderm

3 Entoderm

4 Hypectodermal mesenchyme
5 Hyperentedermal mesenchyme

(i) Mesostroma

7 Coelom

\& Neural plate

Figs. 2 to 4 Dorsal view of a model of the mesoderm and mesenchyme of in embryo of two somites. Columbia collection No. 539, $\times 300$. Reduced $\frac{1}{2}$. The mesoderm sensu stricto is white, the mesenchyme green.

1 First intersonitic cleft

2 Second intersomitic cleft

3 From this point craniad the mesoderm is eontinums arross the median line
4 From this point caudiul the mesoderm is continuous across the mediun line 


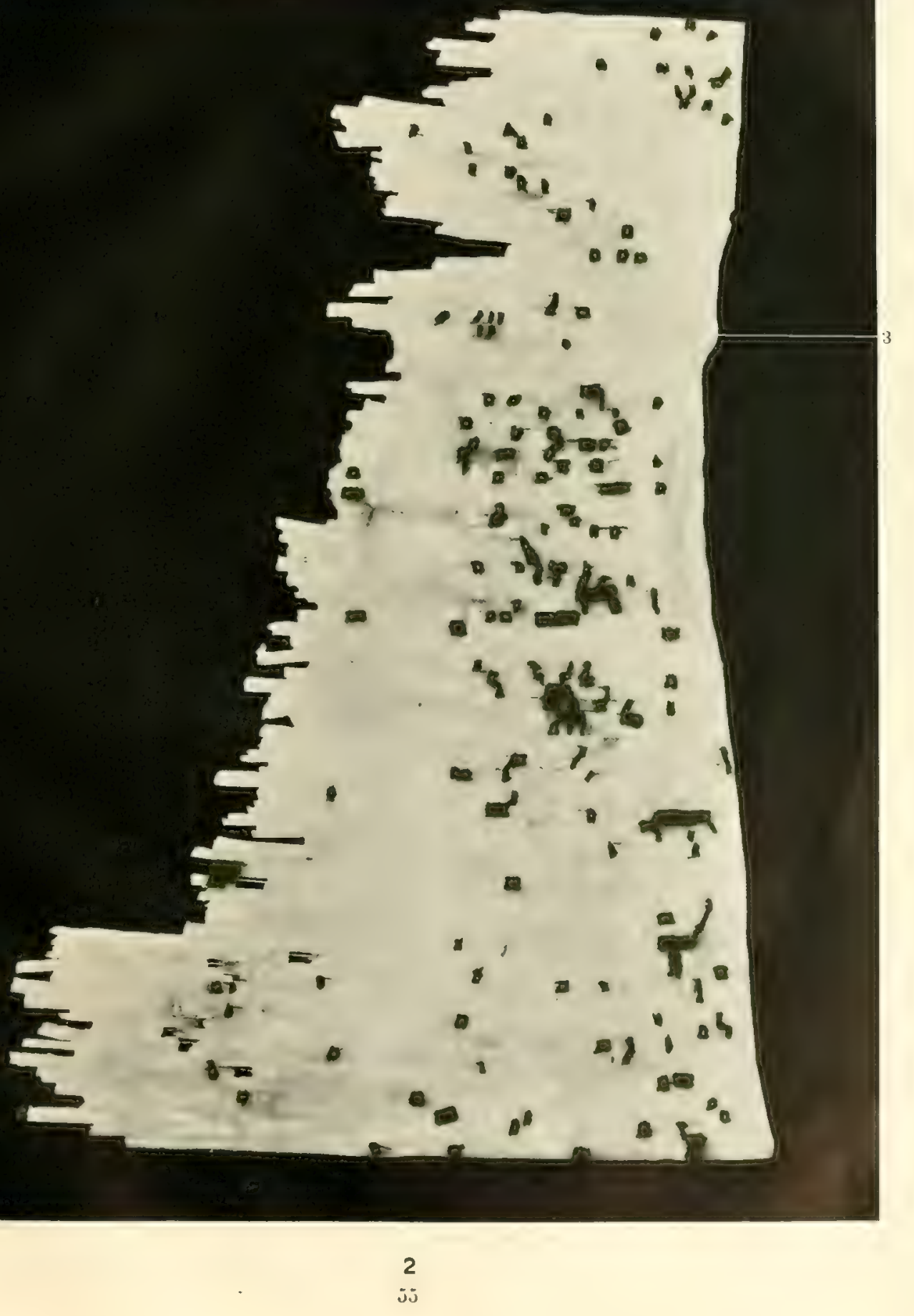


Fig. 3 Dorsal view of a model of the mesoderm and mesenchyme of an cmbryo of two somites. 1, First intersomitic cleft; 2 , second intersomitic cleft. 


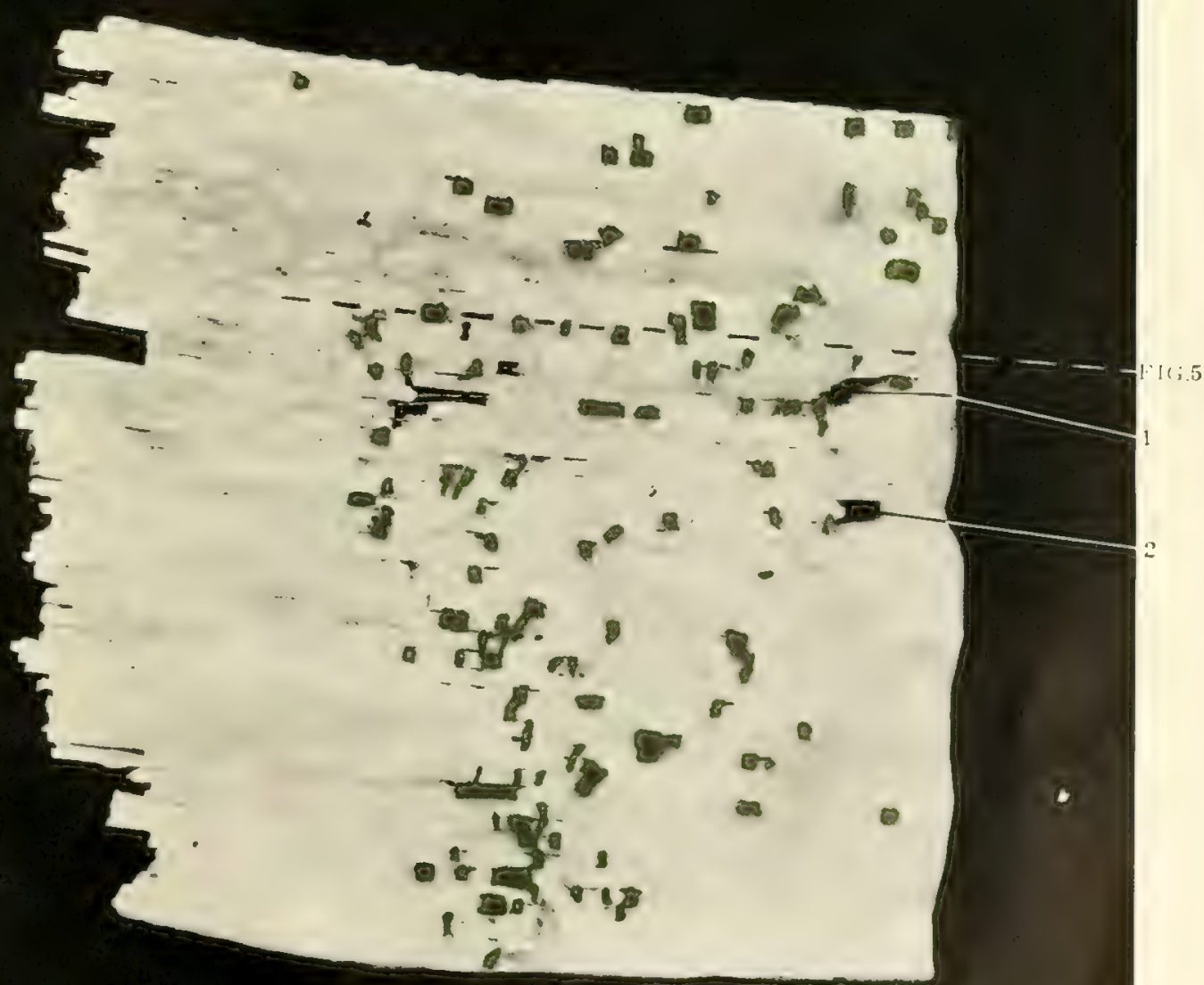


Fig. 4 Dorsal view of a model of the meso lerm and mesenchyme of an embryo of two somites. \&, From this point cauda! the mesolerm is continuous across the median line. 


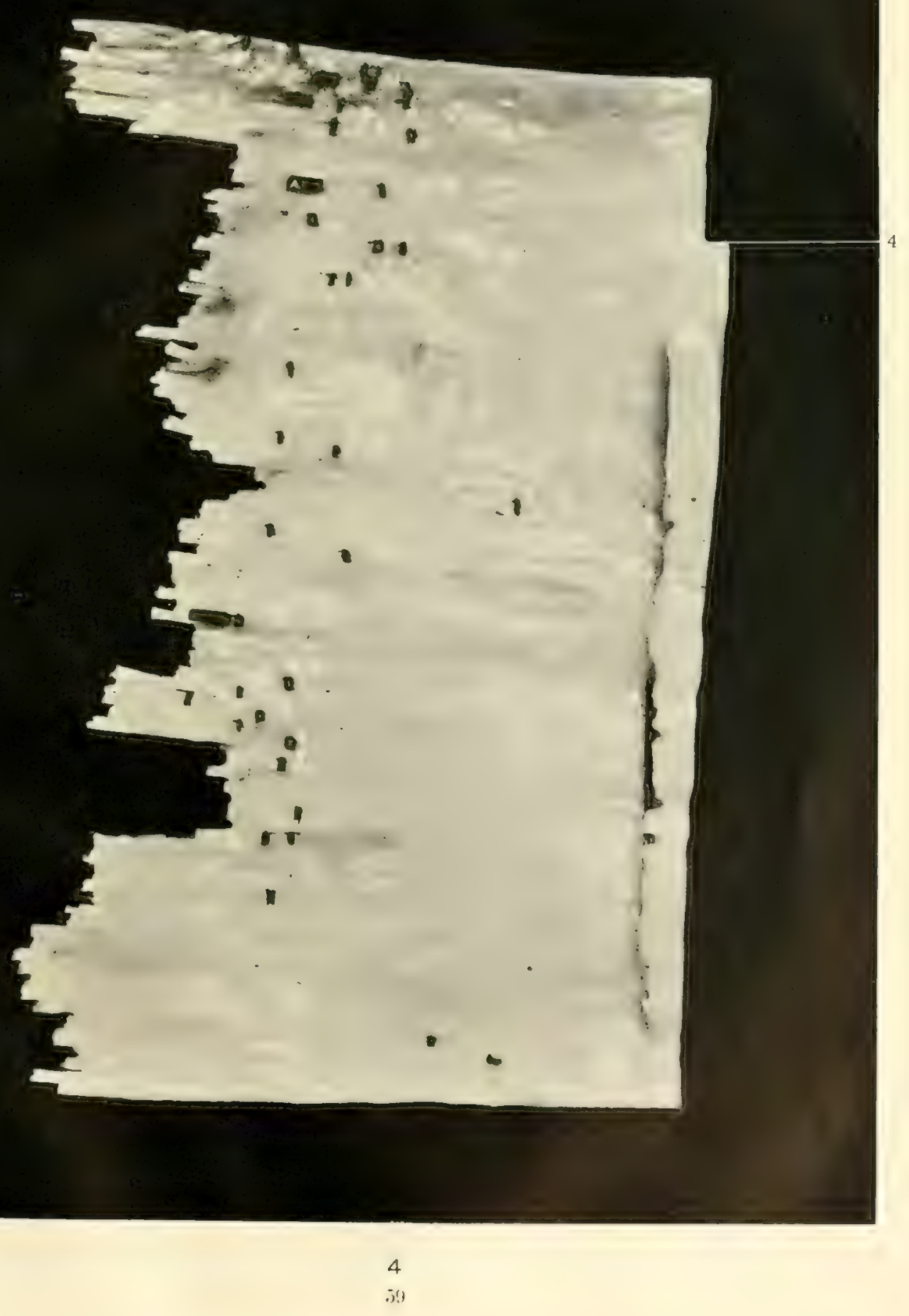




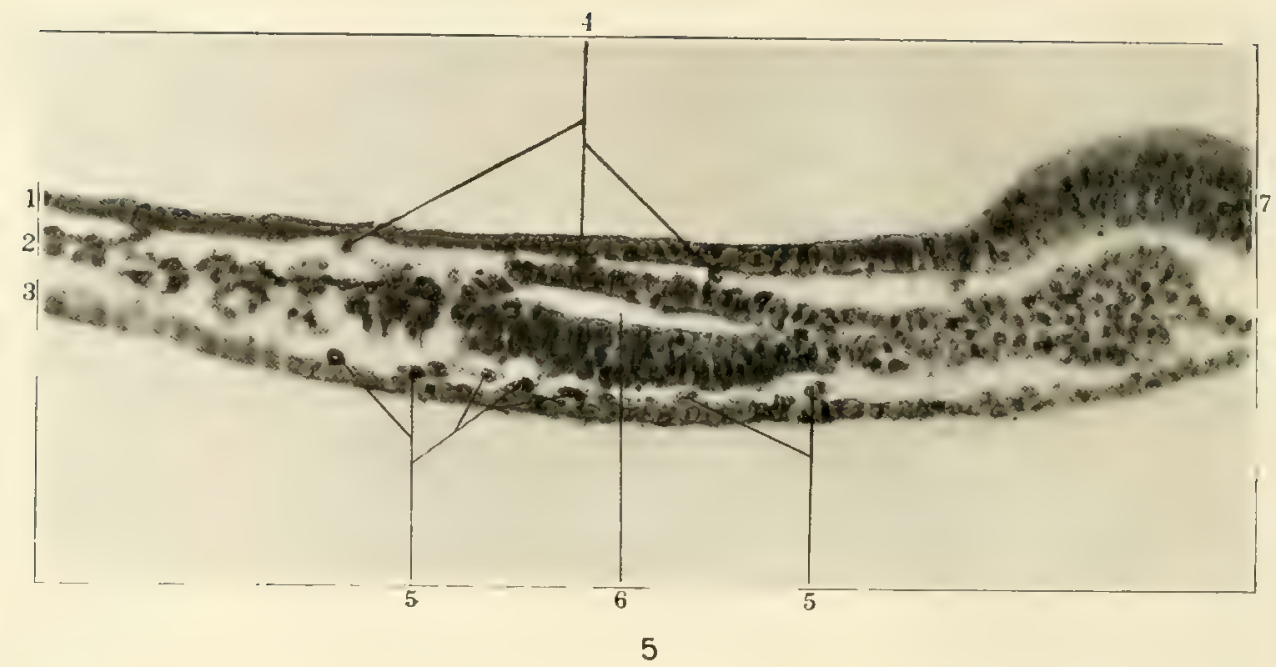

Fig. 5 Transverse section of an embryo of two somites at the level indicated in Figure 3. Slide 5, row 1, section $6, \times 300$. Reduced $\frac{1}{4}$.

1 Eetoderm

2 Mesoderm

3 Entorlorm

1 Hypectodermal mesenchymo
5 Hyperentodermal mesenchymo

(i) Coelom

7 Neural plate

Tig. 6 Dorsal view of model of mesoderm (white), mesenchyme (green) and vasofactive cells (yellow) of an embryo of four somites. Columbia collection No. $409, \times 300$. Reduced $\frac{1}{2}$.

1 Somite 1

2 Inlages of juxta-neural anastomosis

; Connectionbetween the juxta-neural anastomosis and the alorta, (f. fig$111 \mathrm{C} 25$
4 Site of quintal ganglion

5 Endothelial anlage opposite the seconn nephrotome; ef. figures 8 and 9

6 liegion of cardiac coelom 


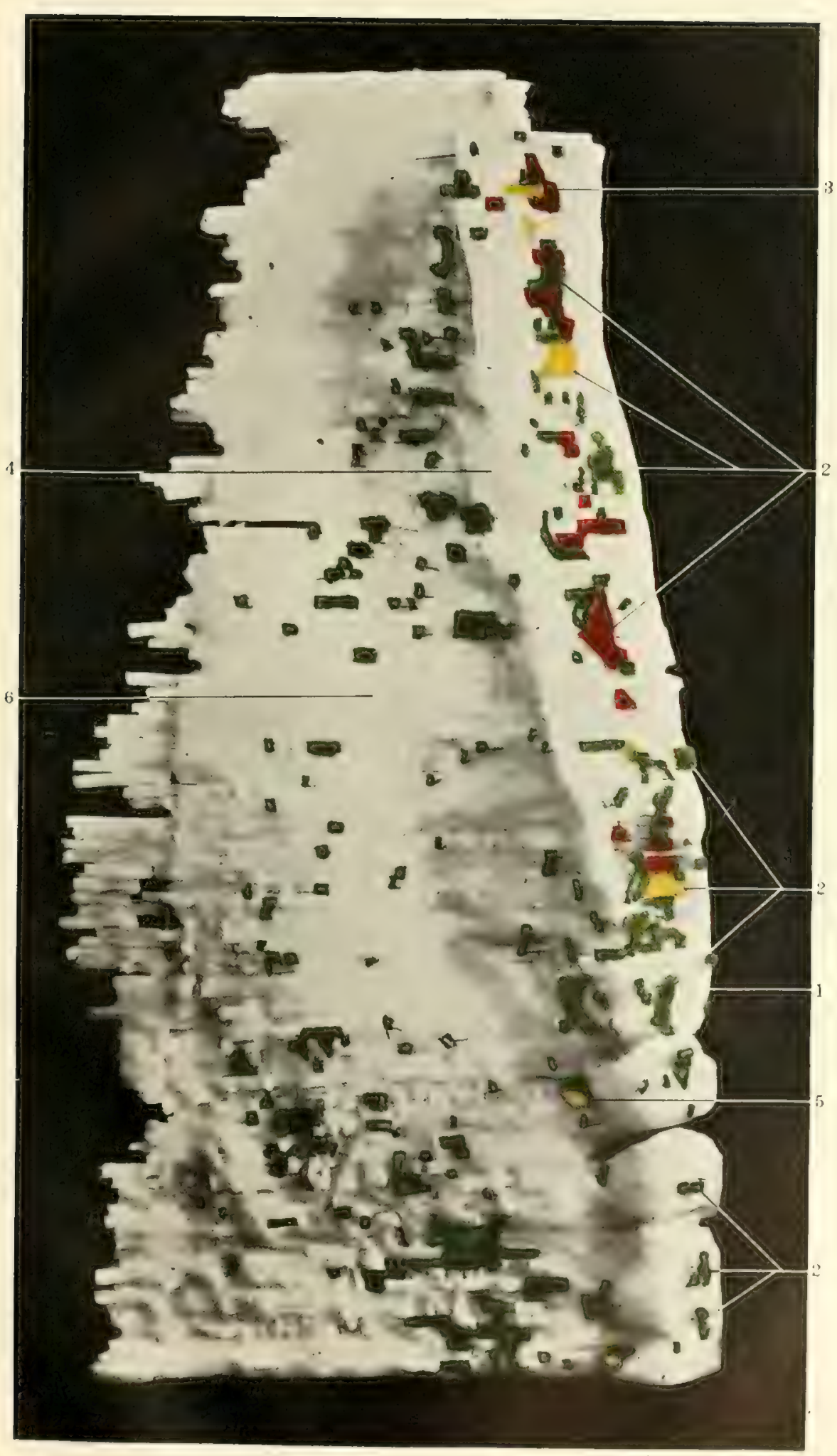


Fig. 7 Dorsal view of model of mesodern (white), mesenchyne (green), vasofactive cells (yellow) and endothelium (red) of an embryo of eight somites. Columbia collection No. $530, \times 300$. Reduced $\frac{1}{2}$.

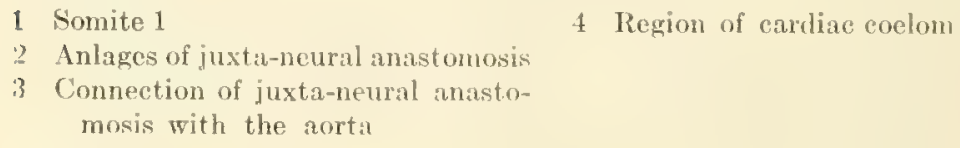




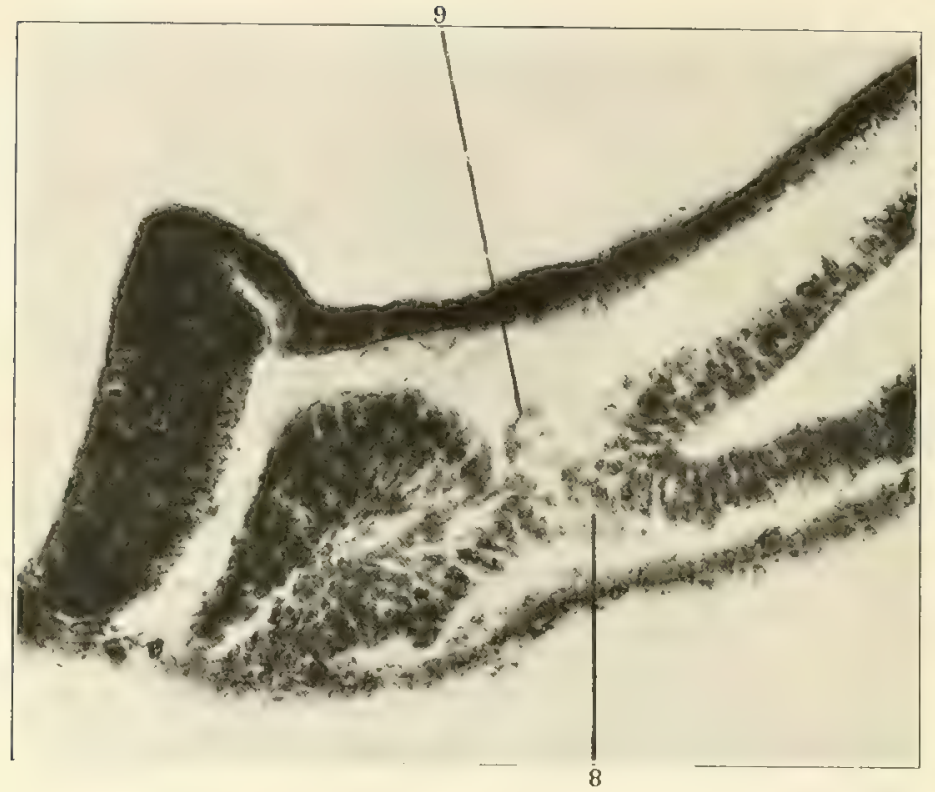

8

Figs. \& and 9 Successive transverse sections of Embryo No. fon passing through the second somite. Left side. Slide 4 row 6 , section 12 and row 5, section $1, \times 300$. Reduced $\frac{1}{4}$. To show derivation of endothelimm from intermediate cell mass.

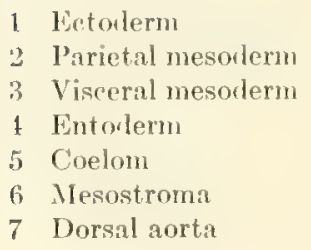

S Intermediate cell mass

9 Projection from intermediate cell mass

10 Endothelial vesicle continuous with the projection from intermediate cell mass of the preceding section

Fig. 10 Graphic reconstruction showing the distribution of cntothelium and vasofactive cells in the somatopleure of an embryo of ten somites. The cavities of angioeysts and clefts in vasofactive cells are shown in red. Columbia collection No. 532. Left side, dorsal view, $X 300$. Reduced $\frac{1}{4}$.

1 Mesal margin of coelom

2 Lateral margin of coelom

3 Angiocysts of umbilical line
1 Angiocysts of eardinal line

5) Somite 1

(i) Somite 5 

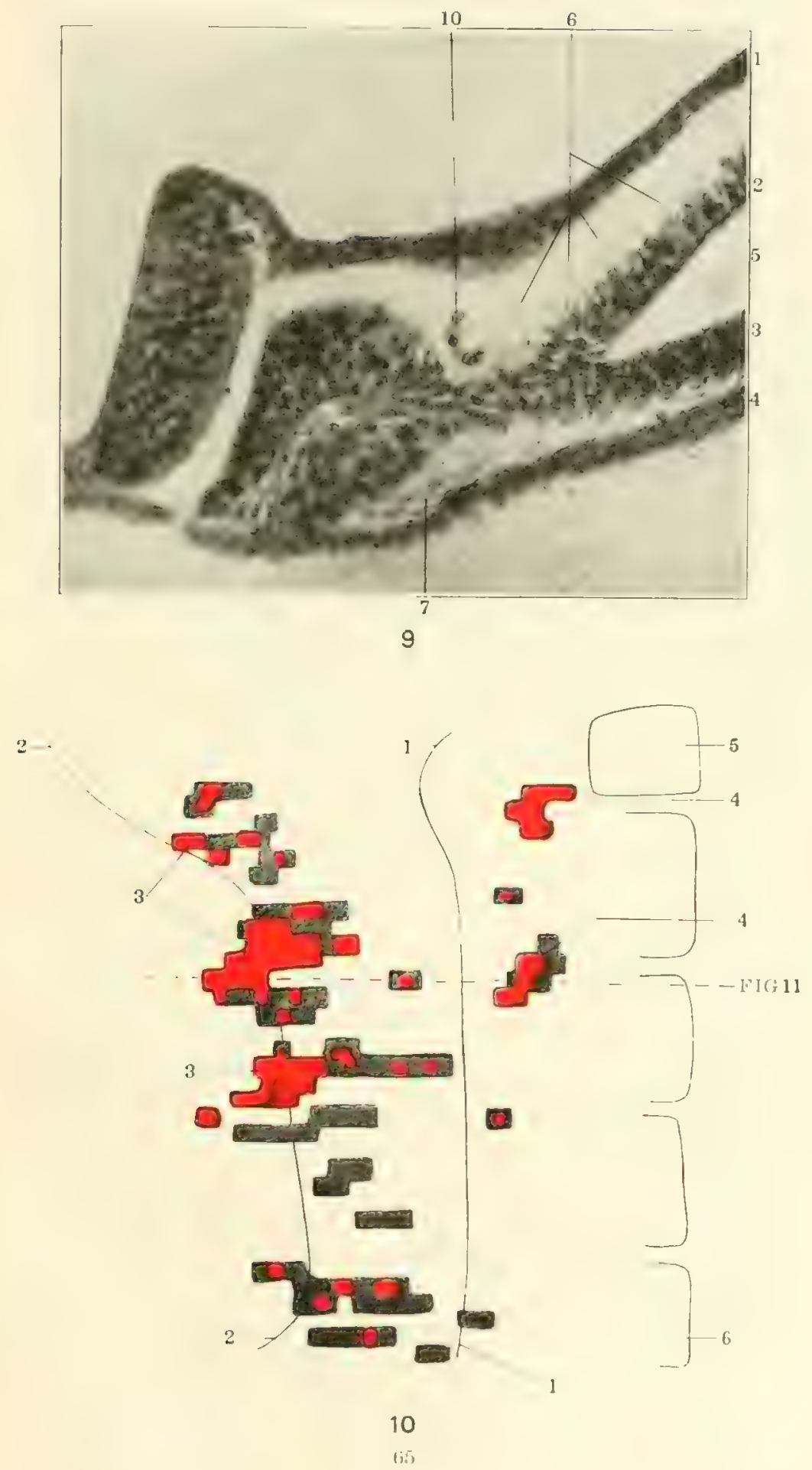


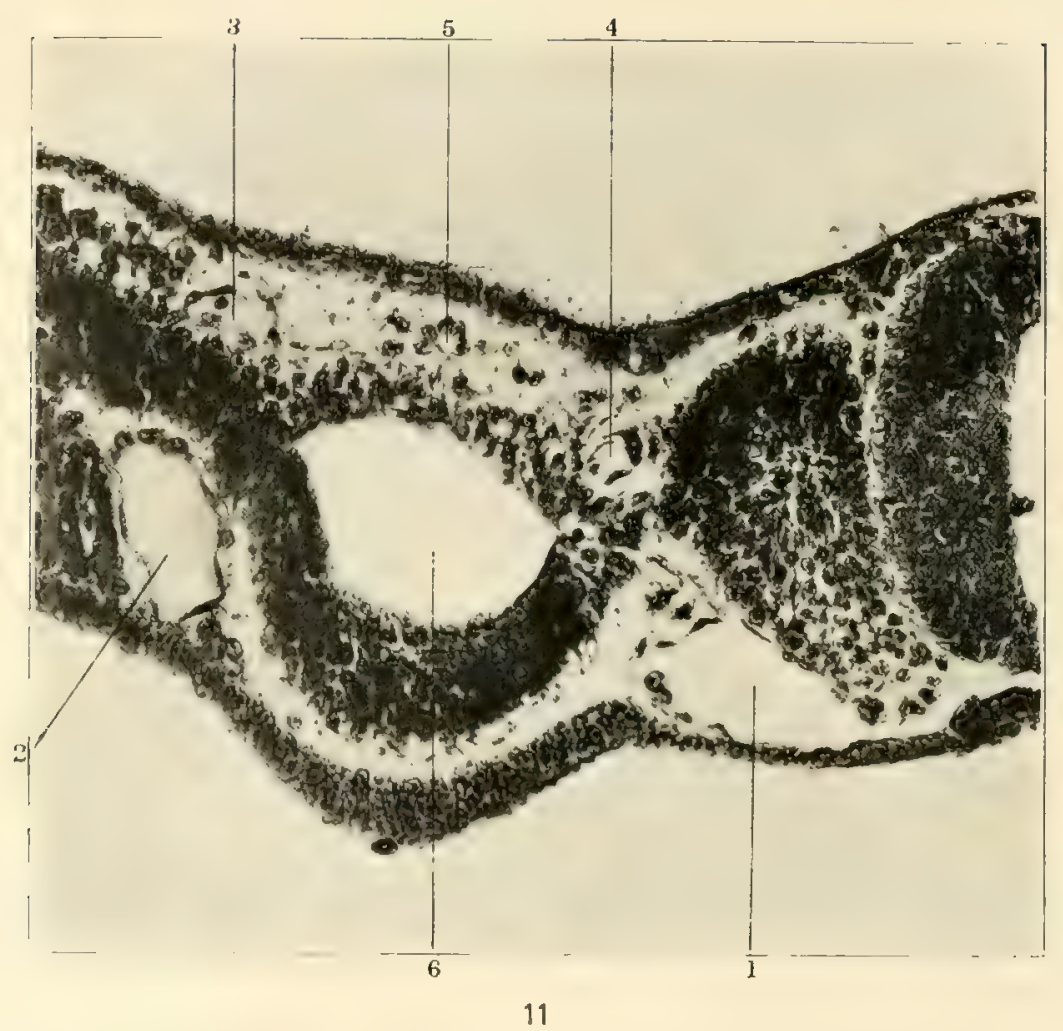

Fig. 11 Transverse section of same embryo at level indicated in preceding ligure, $X 300$. Reducerl ${ }_{4}^{1}$. Slide 6 , row 2 , section 8 .

1 Aortia

2 Omphalomesenteric vein

3 Angiocyst of umbilieal line
4 Angiocyst of cardinal line
i) Angiocyst of intermediate position
6 Coelom

Figs. 12 and 13 Ventral view of model of mesoderm, mesenchyme and vas("ular anlages of an embryo of twolve somites. Columbia Collection No.547. The "oelomic mesoderm from the nephrotomes laterad has been omitted, to allow the lypectodermal mesenchyme (green) to be seen from below, with its endothelium (red), vasofactive cells (yellow) and bloot islands (blue), $X 300$. Reduced ${ }_{2}^{3}$. The umbilicat vein extends into the incipient limb bud.

1 Dorsal aorta

2 'Truncus arteriosus

3 Hypectodermal mesenchyme

A Angioeysts of umbilical vein

5 Coelomic angle (i) Cells derival from visural mesoderm in process of aceretion to the aorta $(\cdot \mathrm{f}$. figure $2 \mathrm{~s}$

7 Mesenchyne about foregut containing anlages of ventral aortic root and raudal artic arches. 


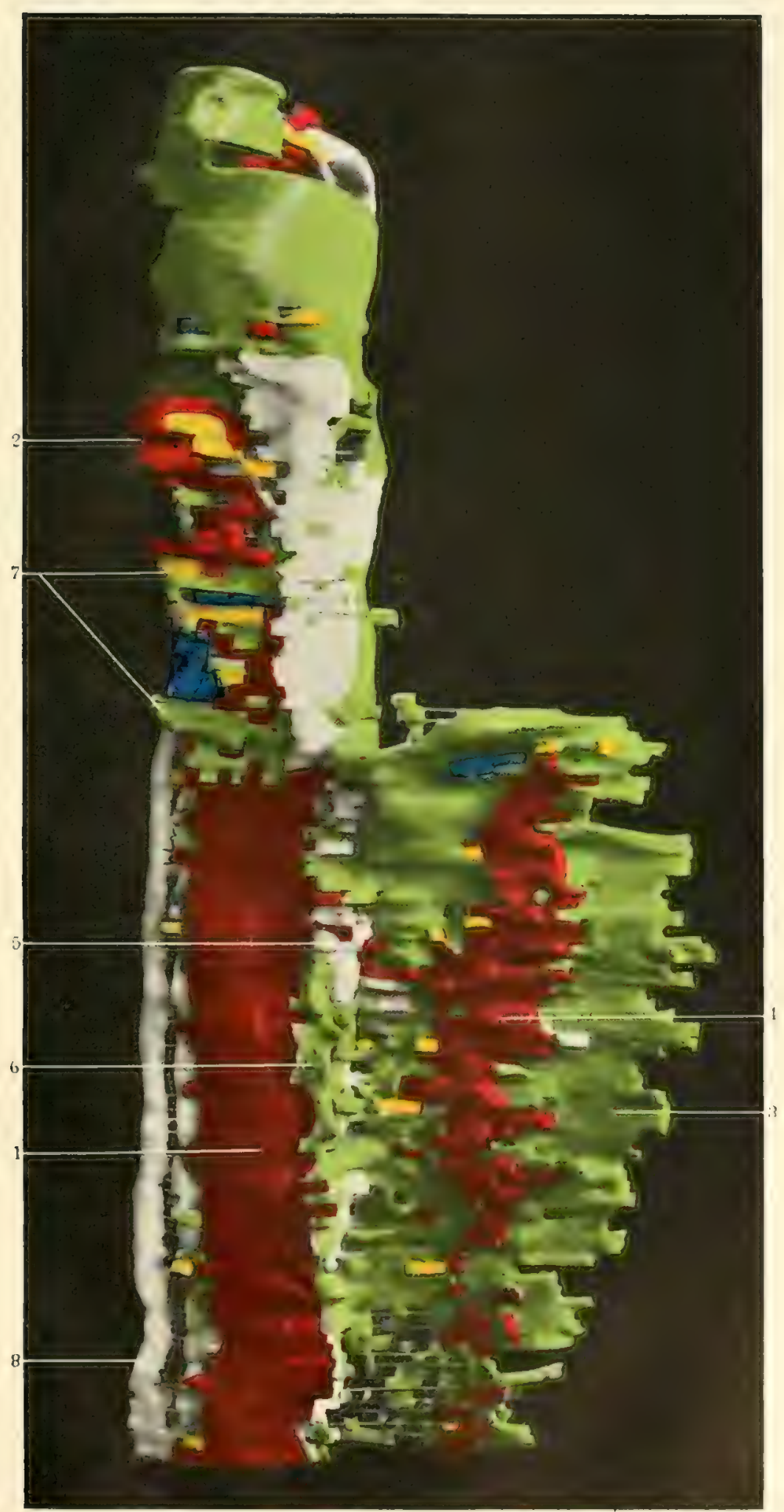


lig. 13 Ventral view of model of mesodem, mesenchyme and vascular anlages of an embryo of twelve somites. 1, Dorsal aorta; 3 , hypetodermal mesenchyme; 4, angioeysts of umbilical vein; 5 , coolomic angle. 


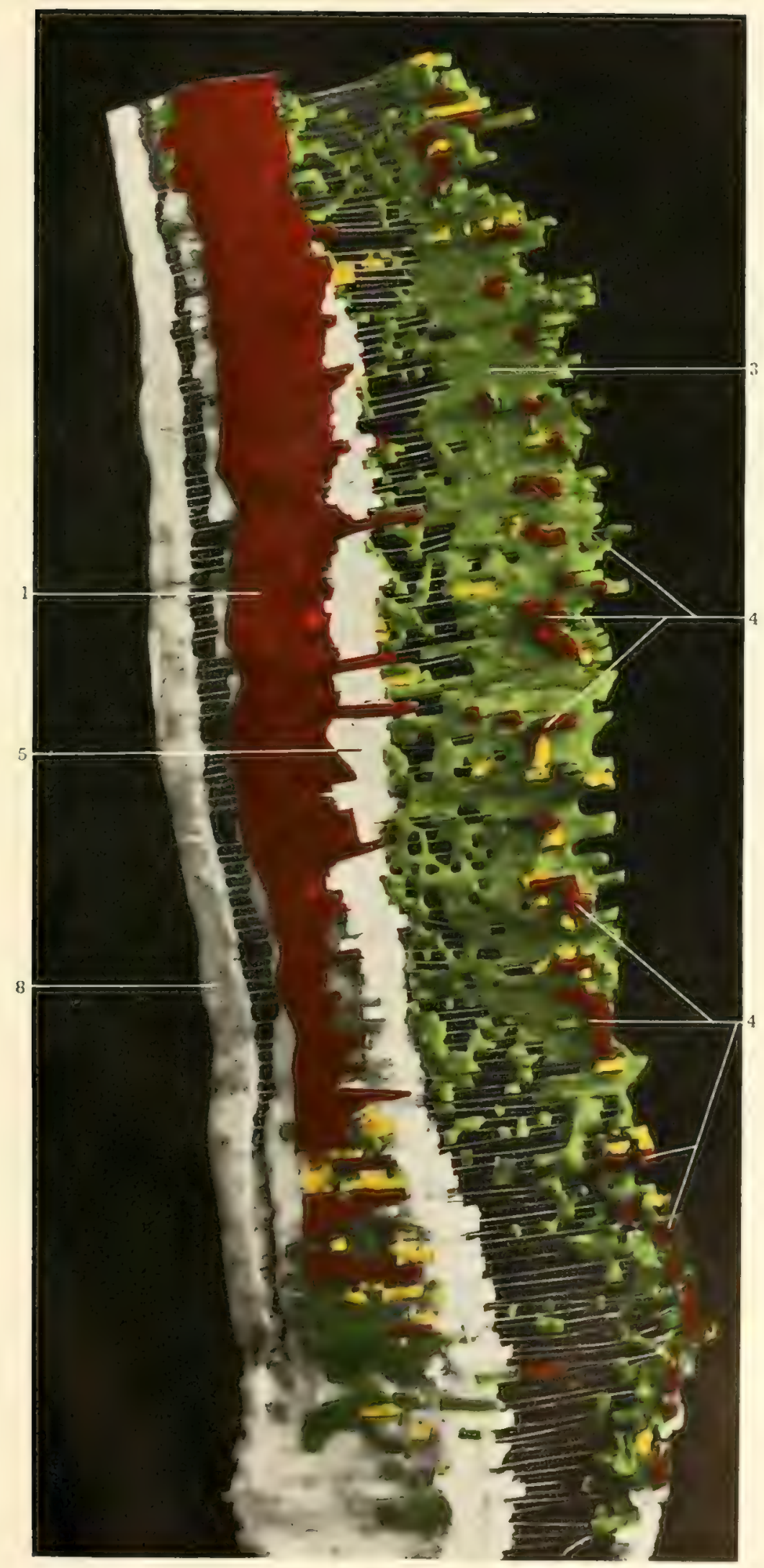




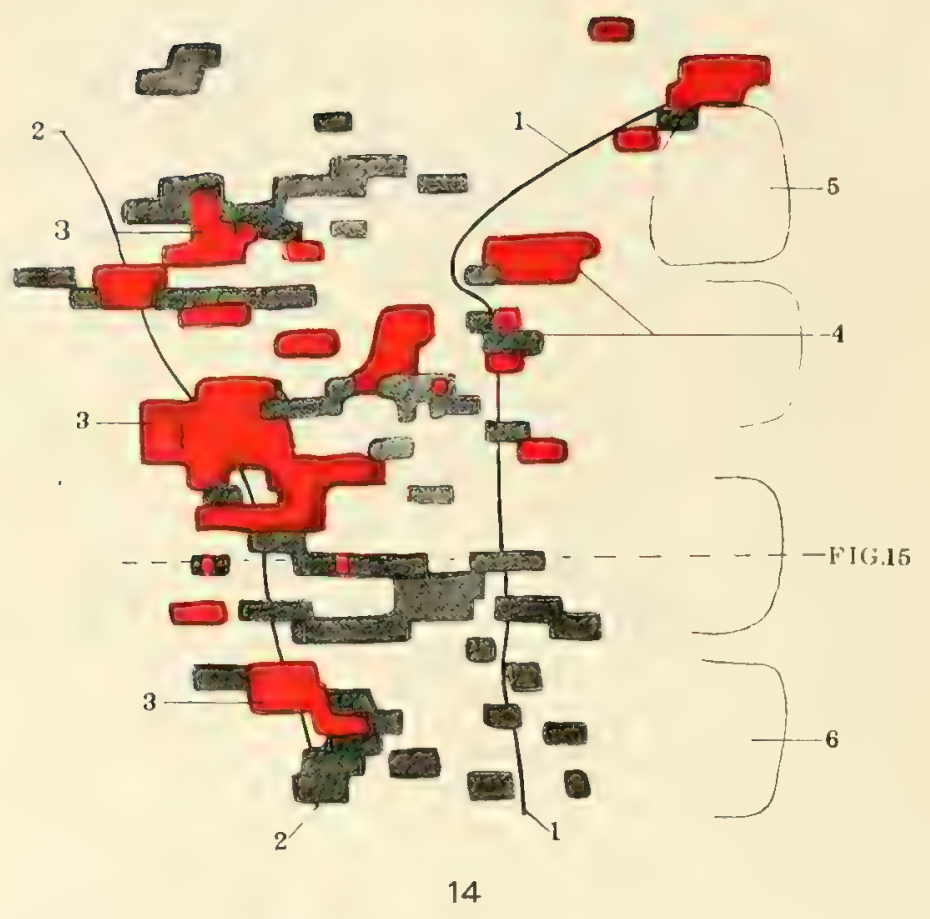

Fig. If Graphic reconstruction showing the distribution of the endothelium and vasofactive cells in the somatopleure of an embryo of twelve somites. The cavities are shown in red. Columbia Collection No. 540, left side, dorsal view, $\times 300$. Reduced $\mathrm{l}$.

1 Mesal margin of coelon

2 Lateral margin of coelom

3. Angiocysts of umbilical line

4 Angiocysts of cardinal line

5 Somite I

(6) Somite 4

Fig. 15 'Transverse section of same embryo at level indicated in figure 14 . Slide 3 , row 2 , section $10, \times 300$. Reduced $:$.

1 Vasofactive cells

3 Coelom

$\because$ Aorta

Fig. 16 Graphic reconstruction of the vessels of the somatopleure and of a portion of the arta from an embryo of fourteen somites. Columbia Collection No. 18s, left side, dorsal view, $\times 300$. Reduced ${ }_{4}^{1}$.

1 Umbilieal vein

2 Site of communication of the umbilical with the omphalomesenteric vein

3 Anterior jugular vein

4 Communications of the anterior jugular vein with the juxta-neural anastomosis
5 Communication between the aorta and the umbilical vein

\section{Aorta}

7 Isolated angiocysts

s Somite ]

9) Somite + 


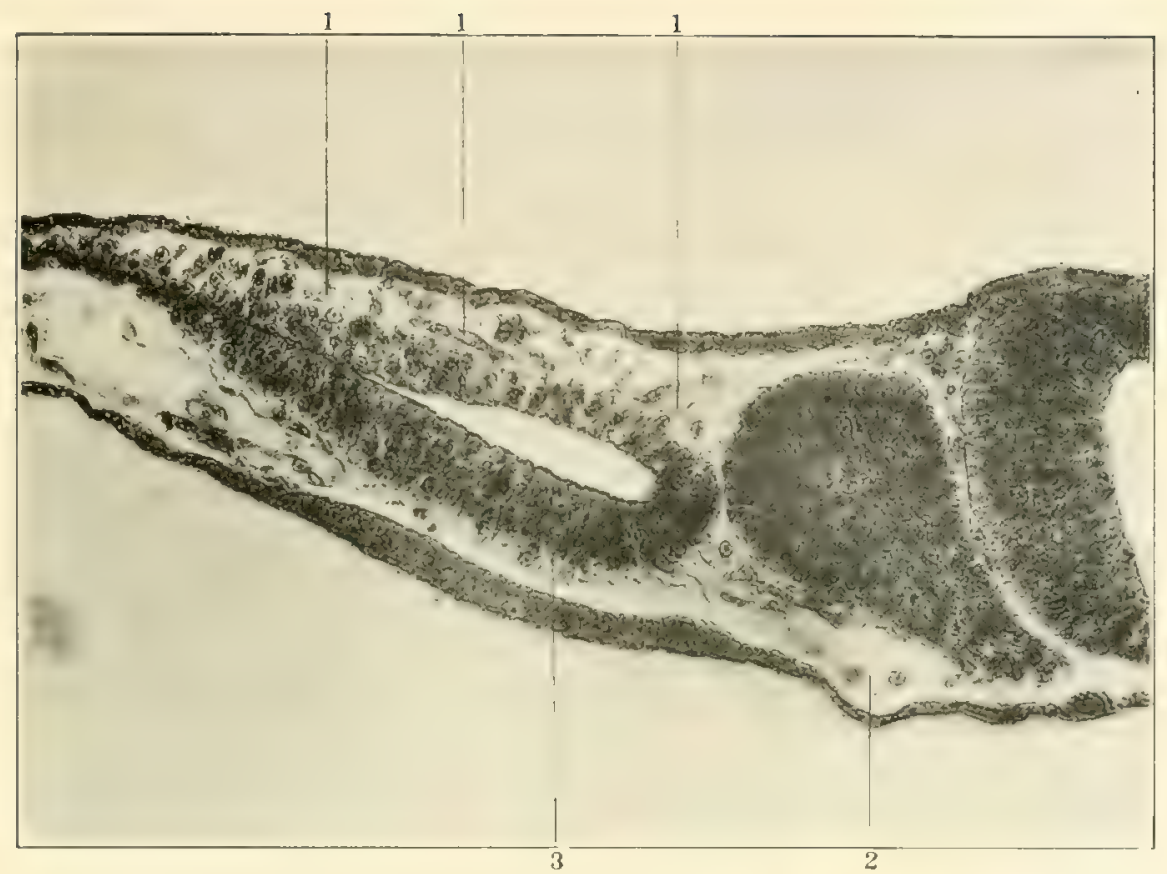

15
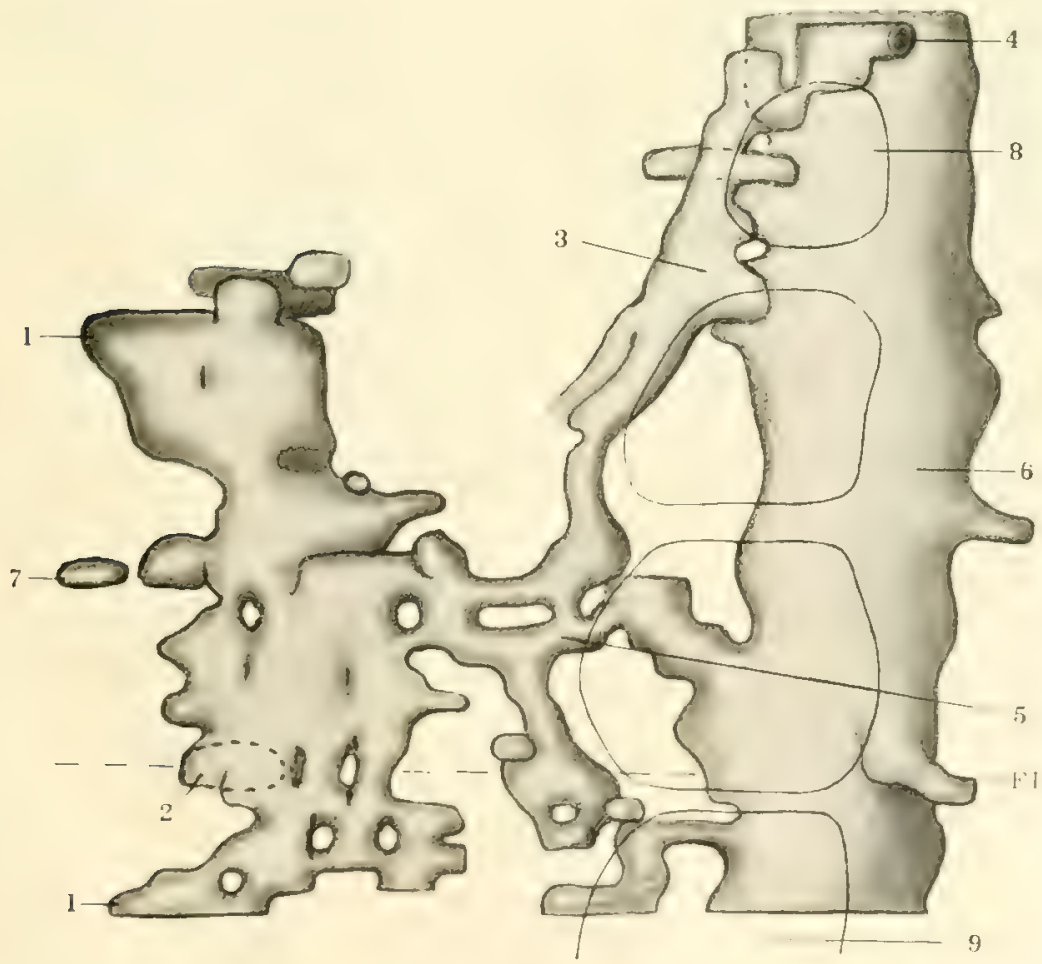


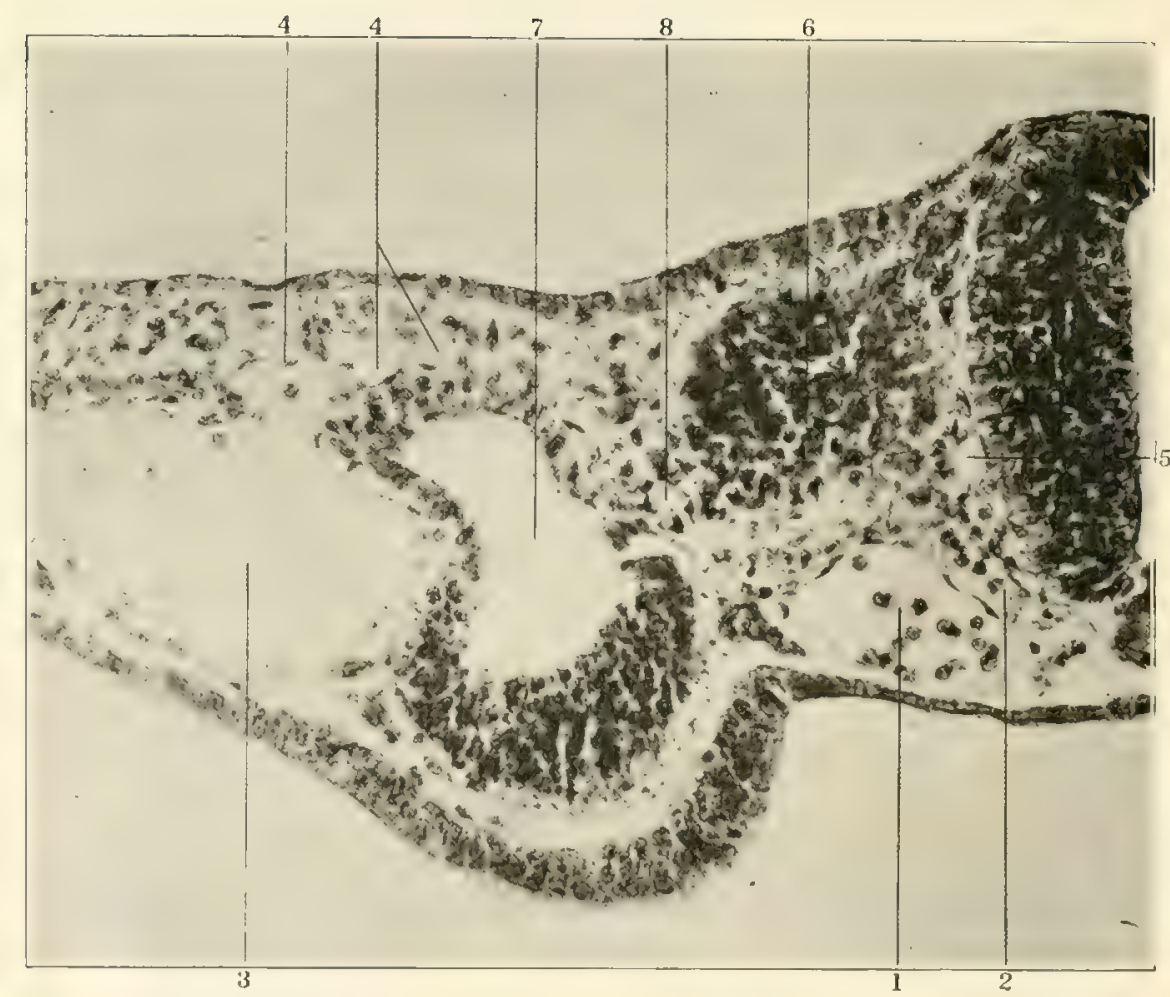

Iig. 17 Transverse section of the same embryo at level indicated in preweding figure, to show the communication between the umbilical and omplatomesenteric veins. Slide 4 , row 4 , section $6, \times 3(\%)$. Restuced $\frac{1}{4}$.
1 Aorta
2 Dorsal segmental arfery
3 Omphalonesenteric vein
5 Juxta-neural vessel
(i) Somite 4
7 Coelom
4 Umbilical vein
s Section of vessel of cardinal position 


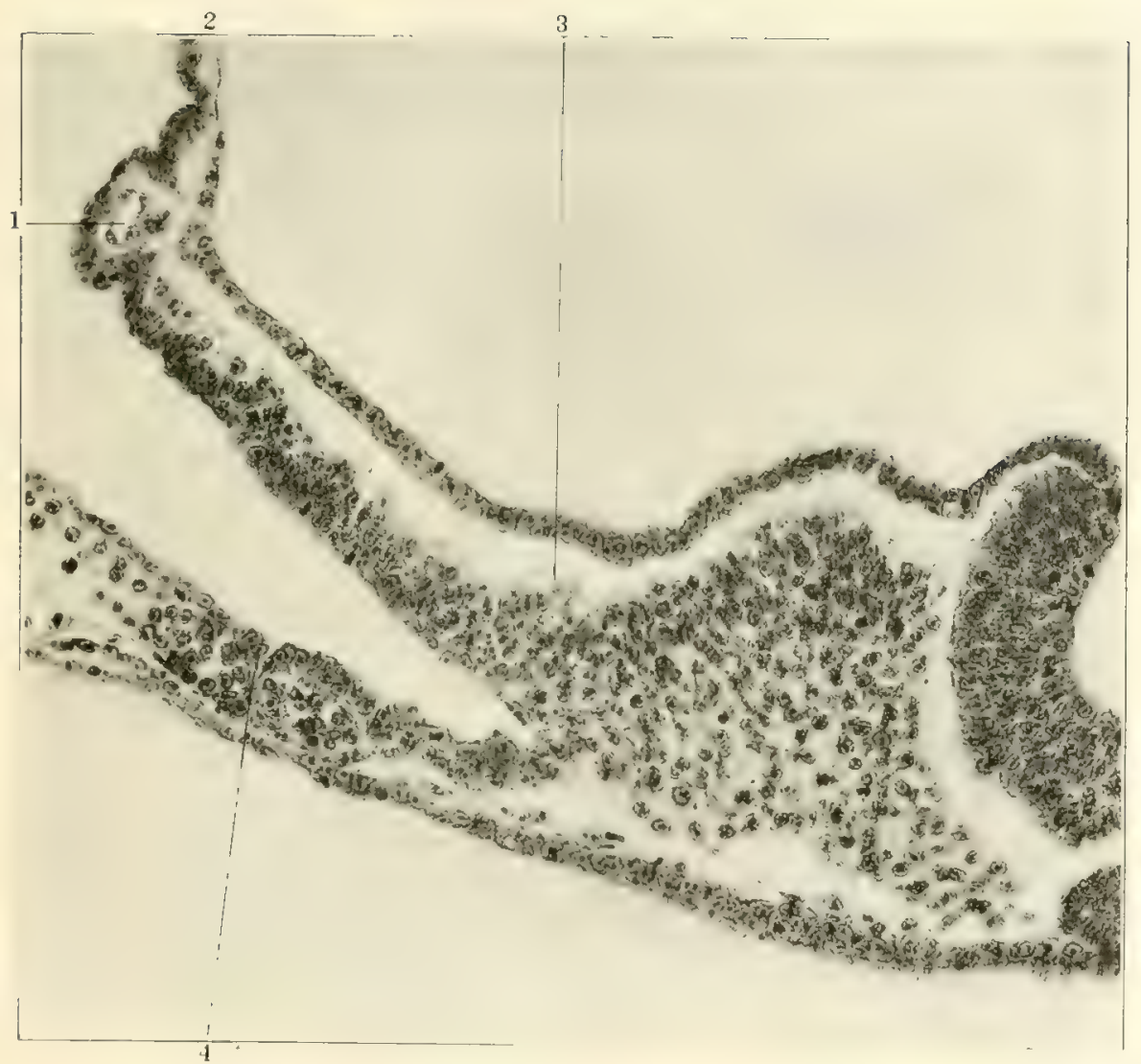

Fig. 18 Transverse section of an cmbryo of twelve somites to show the ammiotic position of the caudal anlages of the umbilical vein. Columbia Collection No. 575, slide 5, row 2 , section $7, \times 300$. Reduced $\frac{1}{2}$.
1 Umbilical angiocyst
3 Amnion
i) Mesostroma
4 finnnol-like diverticulum of eoslom betwern vessels of the splanchno- pleure




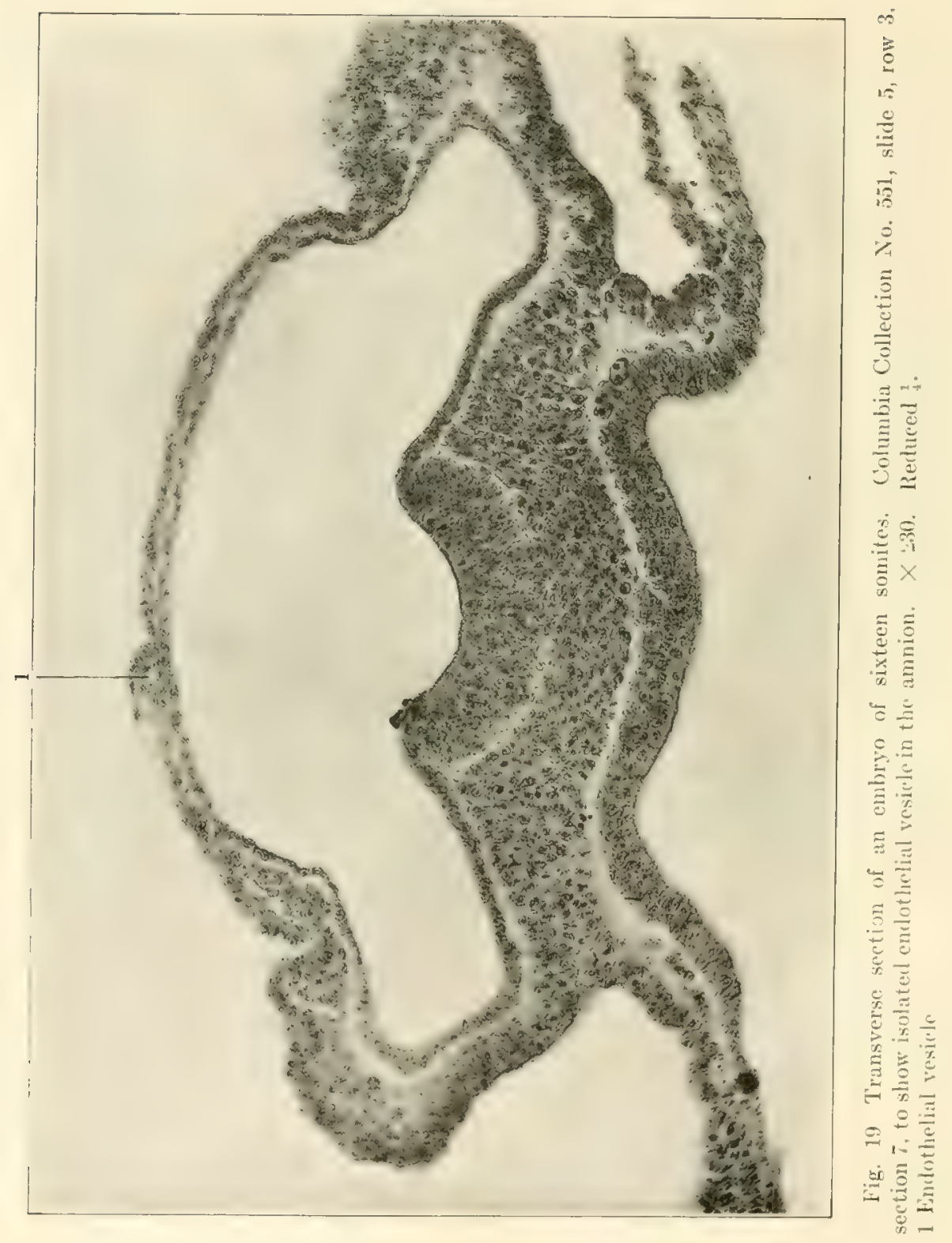



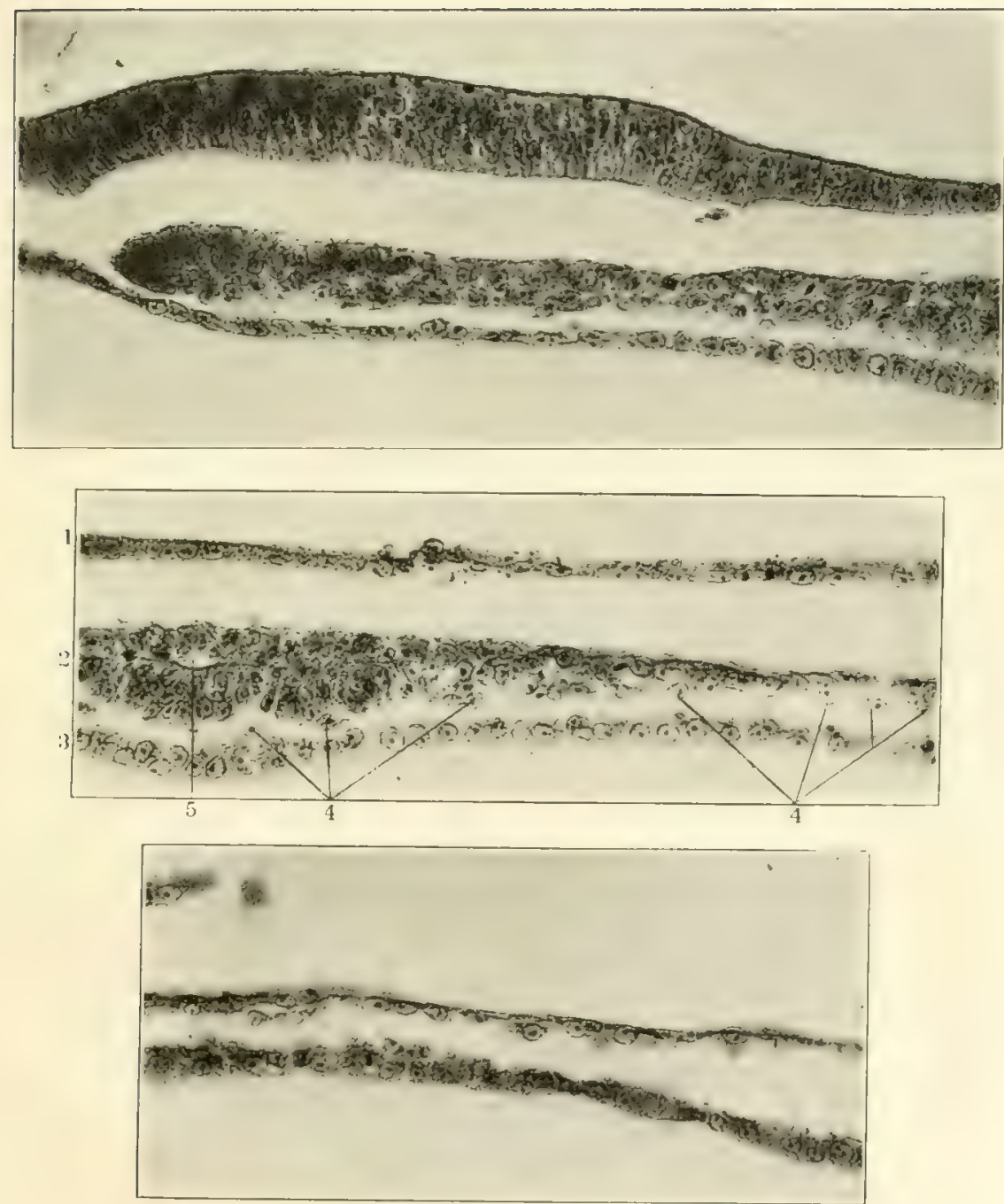

l'ig. 20) Transverse section from embryo in which the somites are forming, but no complete intersomitic eleft has appeared. Columbia Collection No. 5in. slide 3, row 4 , section $6, \times 300$. Redueed $\frac{1}{4}$

$\begin{array}{ll}1 & \text { Ectoderm } \\ 2 & \text { Mesoderm } \\ 3 & \text { Entoderm }\end{array}$
4 Hyperentodermal mesenehyme and incipient blood islands

5 ('oplom 
Figs. 21 to 23 Ventral view of a model of the mesoderm (white), splinchnofleuric mesenchyme (green), vasofactive colis (yellow) and endothelium (red) of an embryo of two somites. Columbia Collection No. 539, $\times 300$. Reduced $\frac{1}{2}$.

1 Anlages of ventral aorta and heart

2 Anlages of dorsal aorta

3) First intersomitic eleft

1 sireond intersonitic cleft
5. From this point eraniad the mesoderm is continuous across the median line

(; From this point caudad the mesoderm is continuous arross the median line 


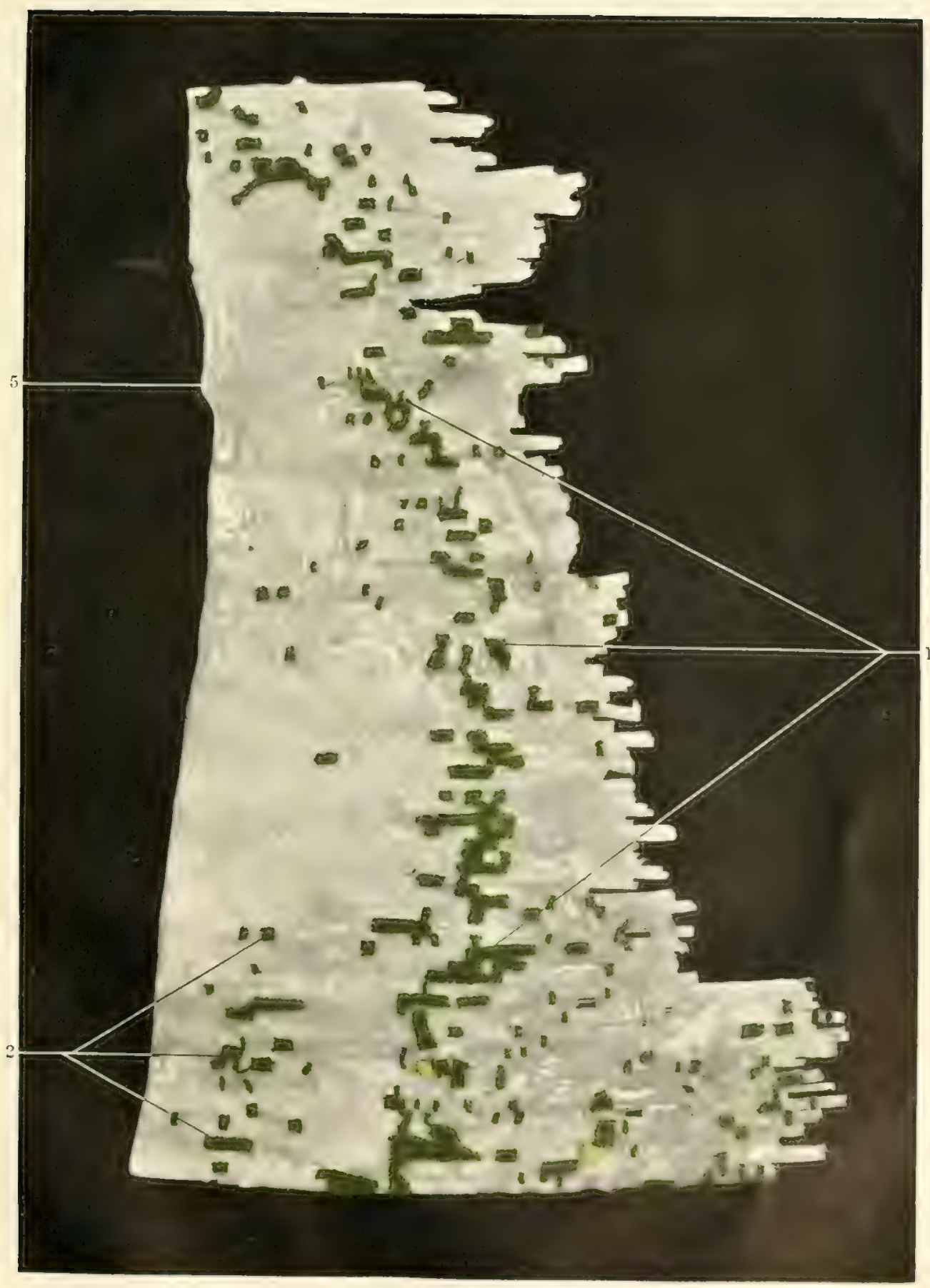


Fig. 22 Ventral view of a model of the mesoderu (white), splanchopleuric mesenchyme (green), vasofactive cells (yellow) and endothelium (red) of an cmbryo of two somites. 2. Anlages of dorsal aorta; 3, First intersomitic cleft; 4. second intersomitic cleft. 


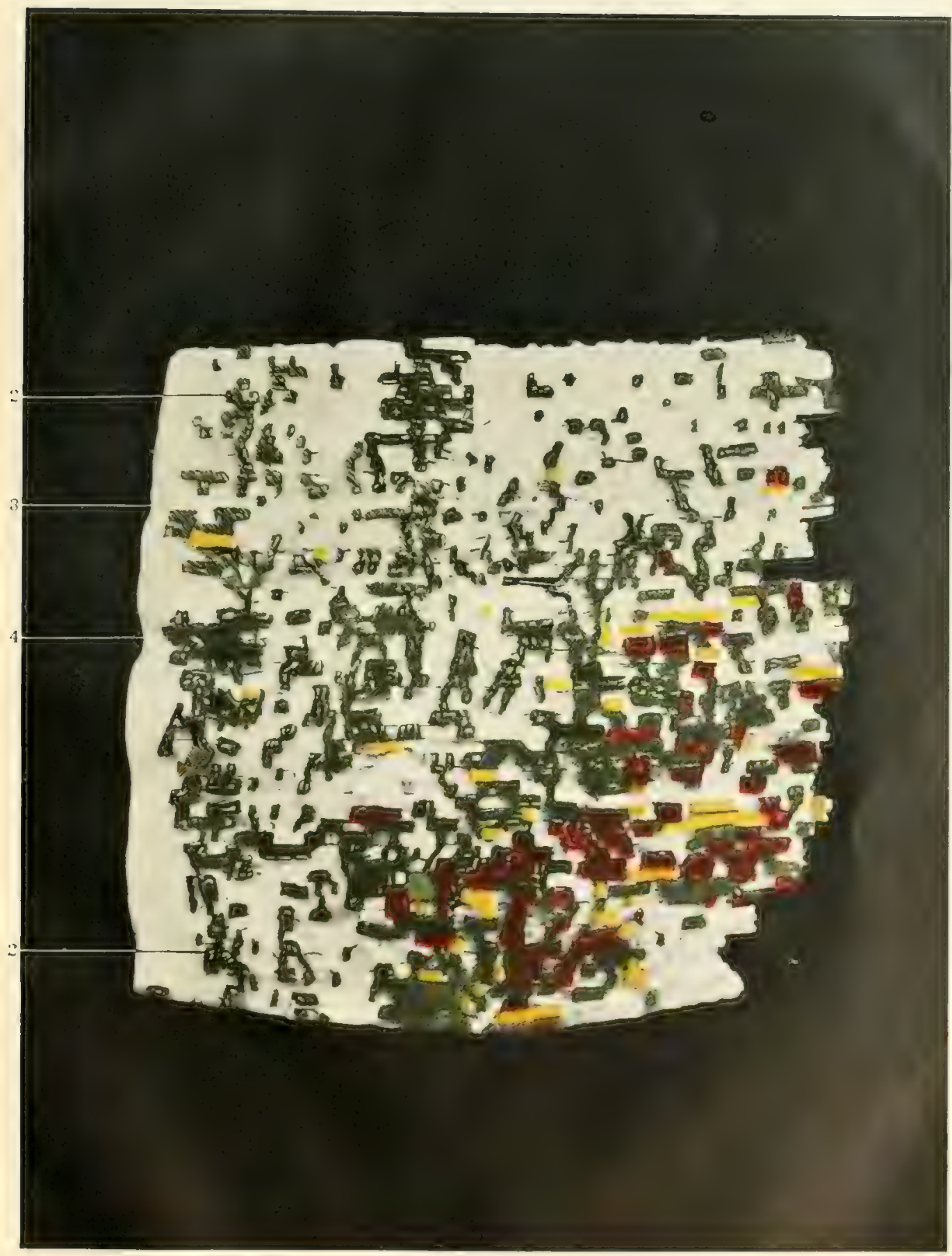


Fig. 23 Ventral view of a model of the mesoderm (white), splanchnopleuric mesenchyme (green), vasofactive cells (yellow) and endothelium (red) of an embryo of two somites. 6 , From this point eaudal the mesorlerm is continuous across the median line. 


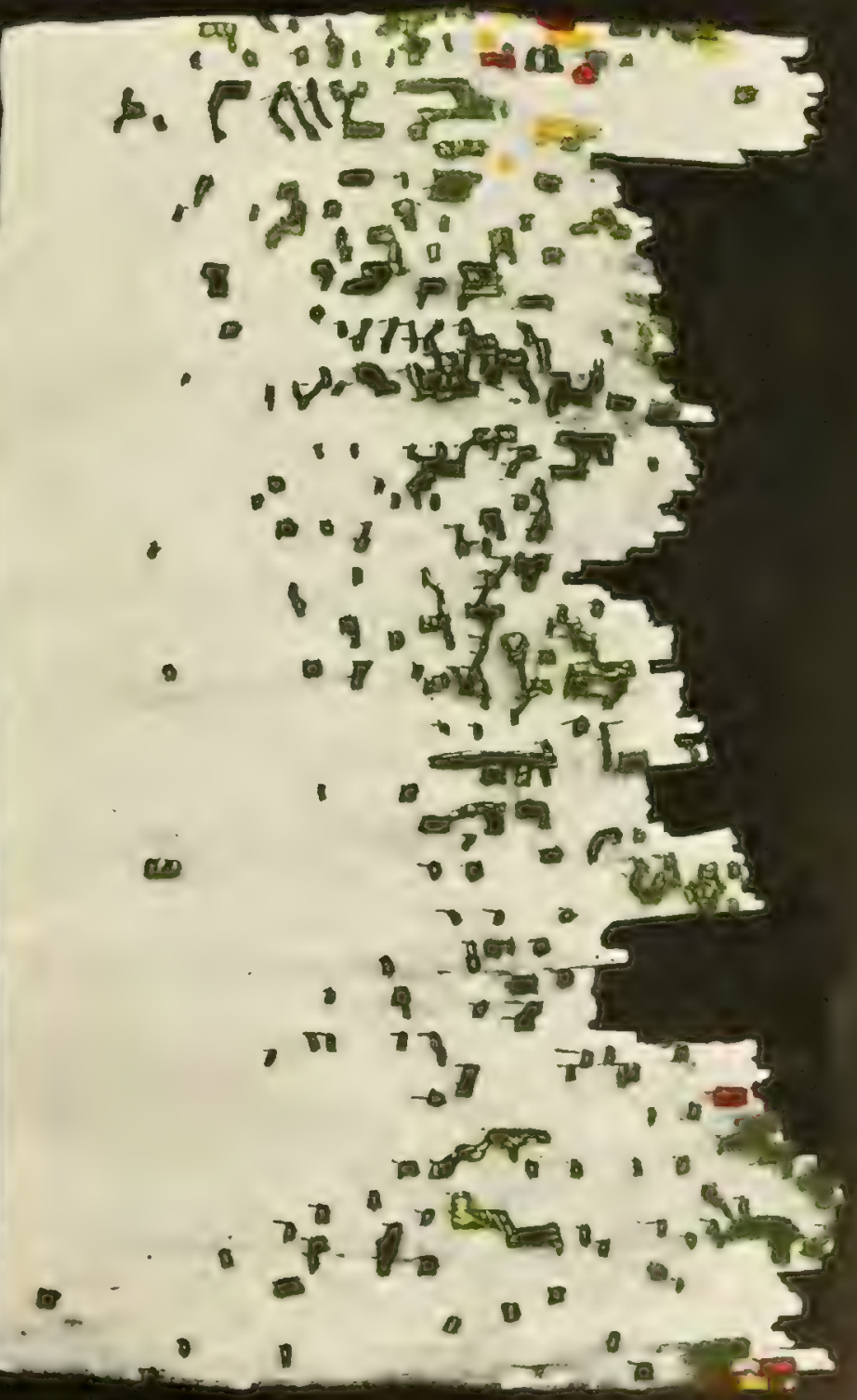


Fig. 2t Ventral view of a model of the mesoderm (white), hyperentodermal mesenchyme (green) vasofactive cells (yellow) and endothelium (red) of an embryo of four somites. Colunbia Collection $\mathrm{Y}$ \%. $409, \times 30 \%$. Reduced!

1 Anlages of the dorsal anorta

2 First aortic arch

3 Anlages of ventral aortil
4 Position of heart

i) Omphalomesenterie vein

(i) Omphalomesenteric plexus 


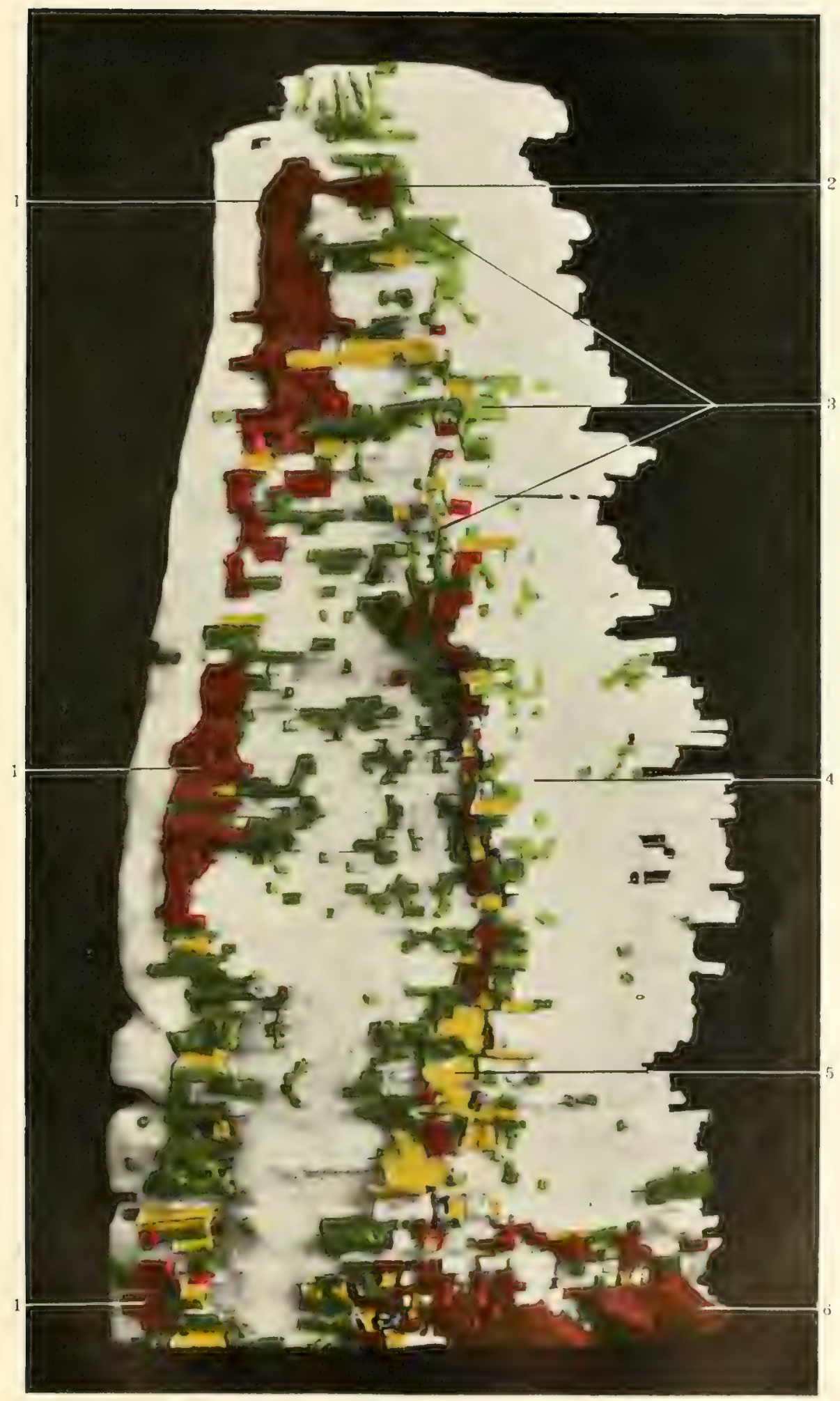




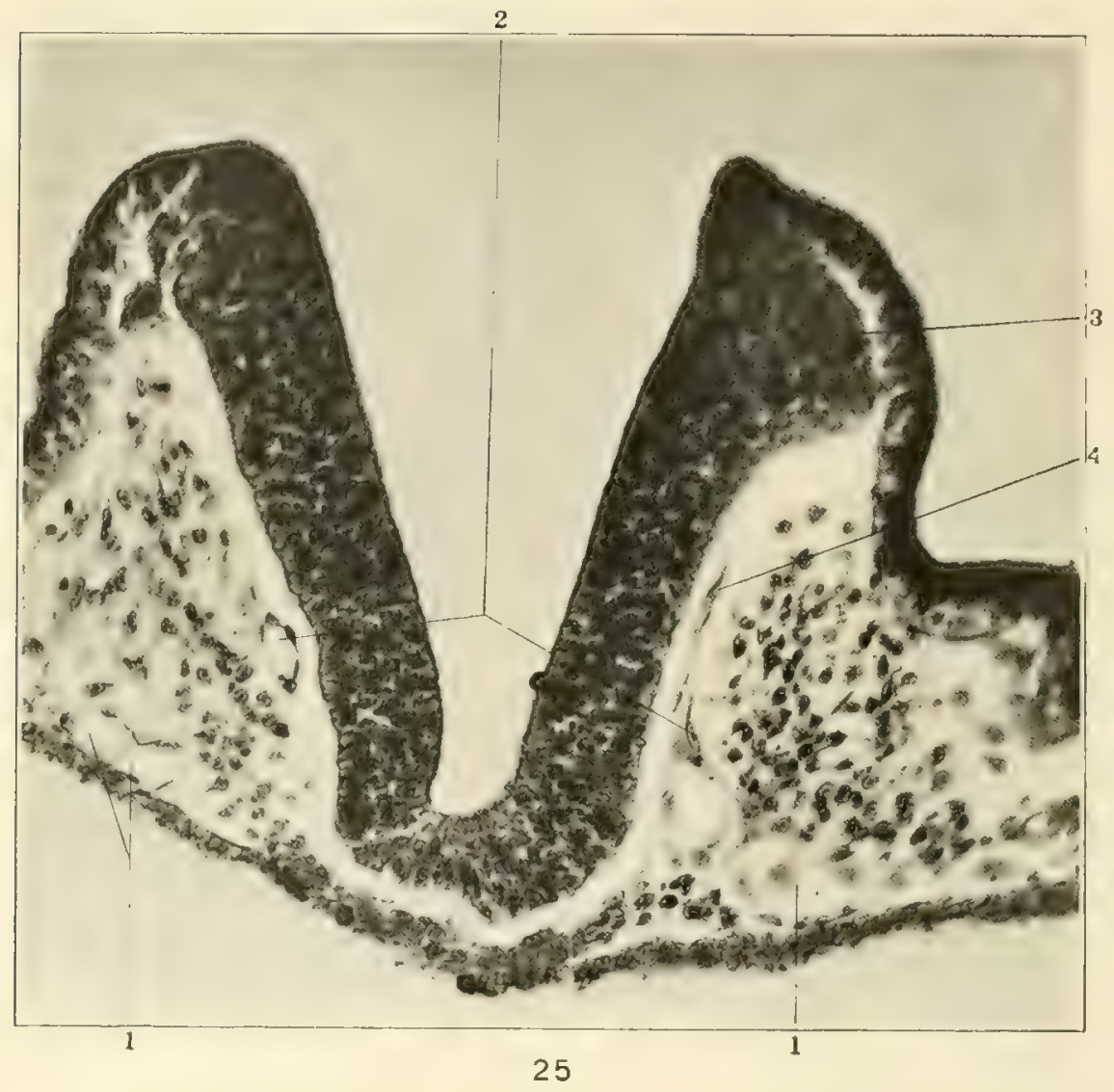

Fig. 25 'Transverse section of an embryo of four somites at the level indicater by leater 3 in figure 21. Columbia Collection No. 409, slide 5, row 6, section 3, $<300$. Reduced 1 . The several angyocysts are in entact but their lumina are not continuous.

1 Aorta

2 Juxta-neural line

3 Quintal anlage
4 Vasofactive cells attached to juxtaneural vessel; this cleft-like lumen is not continuous with that of the vessel

ing. 26 Ventral view of a model of the mesolerm (white), mesenchyme (green). vasofactive cells (yellow) and endothelium (red) of an embryo of eight somites. Columbia Collection No. 530, $\times 300$. Reluced $\frac{1}{2}$.

1 Dorsal aortil

2 Omphalomesenteric vein

3 Omphalomescnteric plexus
4 Projections of visceral mesoderm which later become ronnected with the aorta

i) Position of heart 


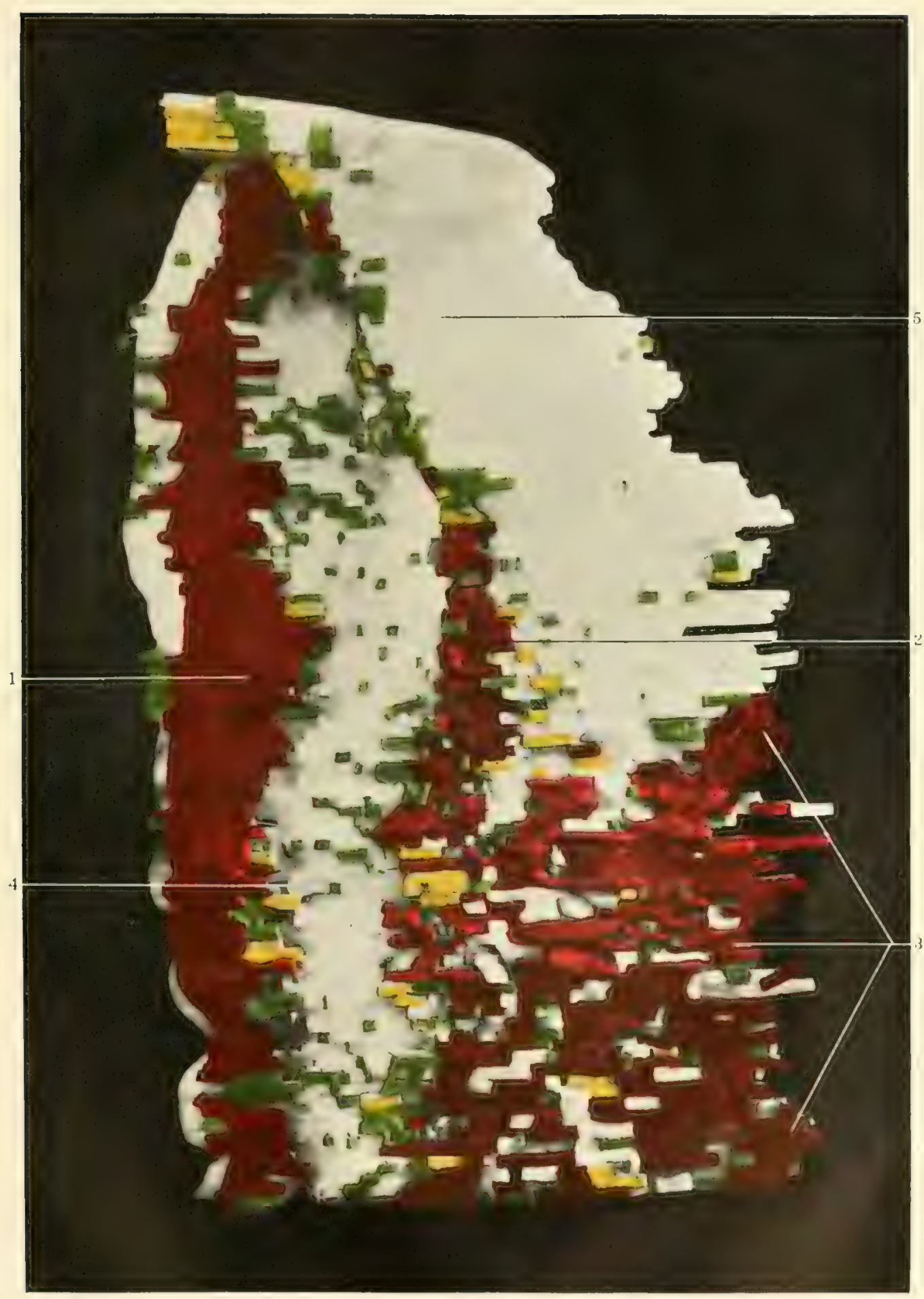




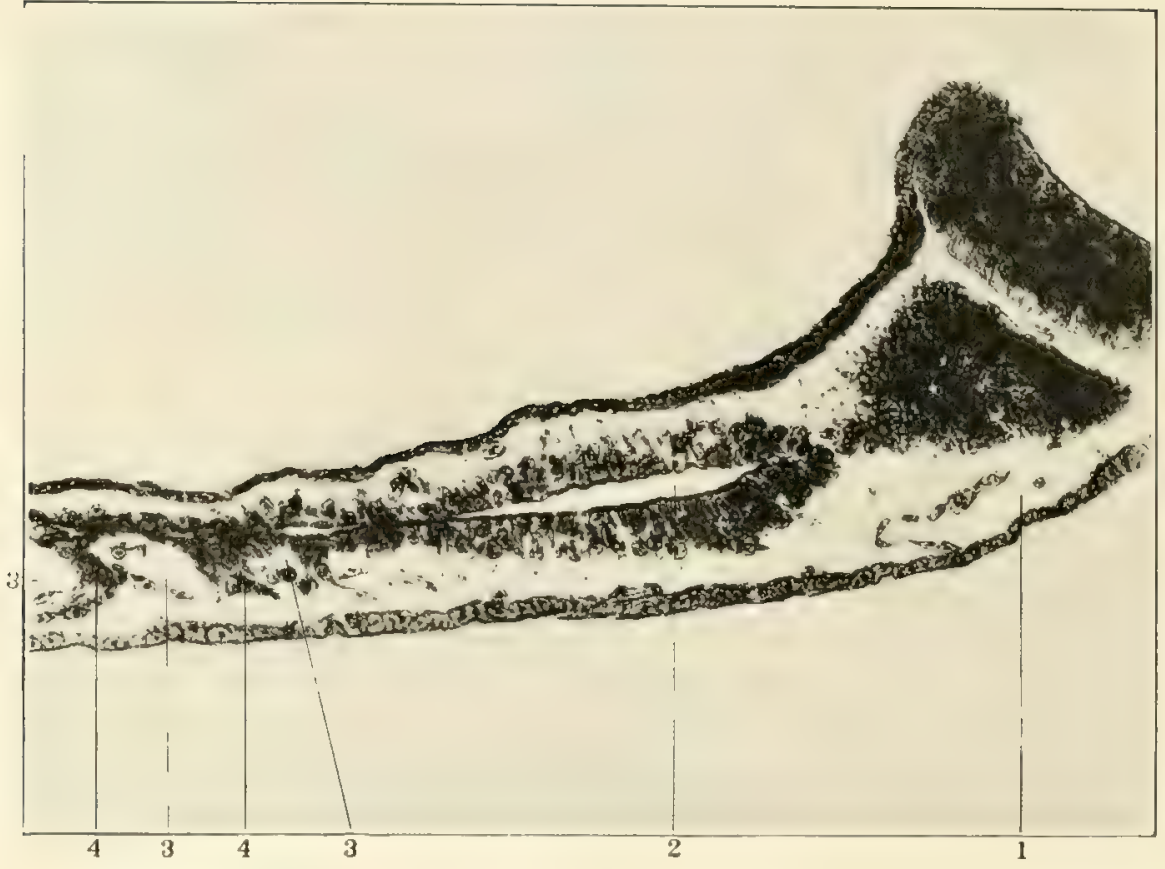

Fig. 27 Transverse section of an embryo of eight somites, Columbia Collecetion 530 , slide 7 , row 4 , section $4, \times 300$. Reduced $\frac{1}{4}$.
1 Aorta
2 Coelom
3Omphalomesenteric plexur
4 Projections of mesoderm betwen blood vessels




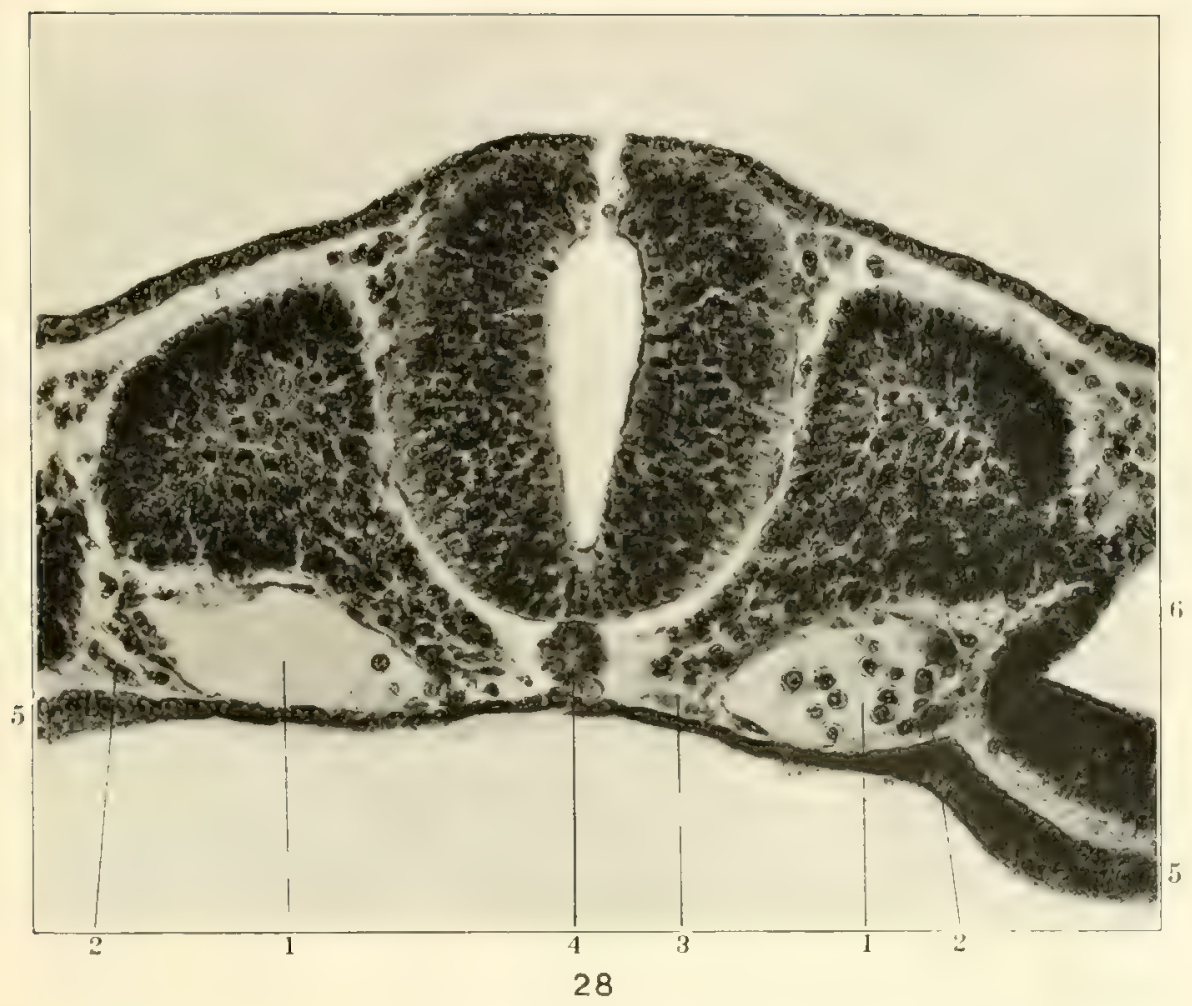

Figs. 2s to 33 serial transverse sections of an embryo of twolve sonites. Columbia Collection No. 5t7, slide 7 , row 2 , sections 7 to $12, \times 300$. Reduced ${ }_{4}$.

1 Sorta

2. Cells derived from visceral mesoderm in process of accretion to the aorta

;Cells of selerotome in syncytial continuity with enclothelium of atort

\section{+ Notocoril}

5) Entodern

6 Coelom

7 Angiocyst added to aorta; a remnant of septum is still visible 


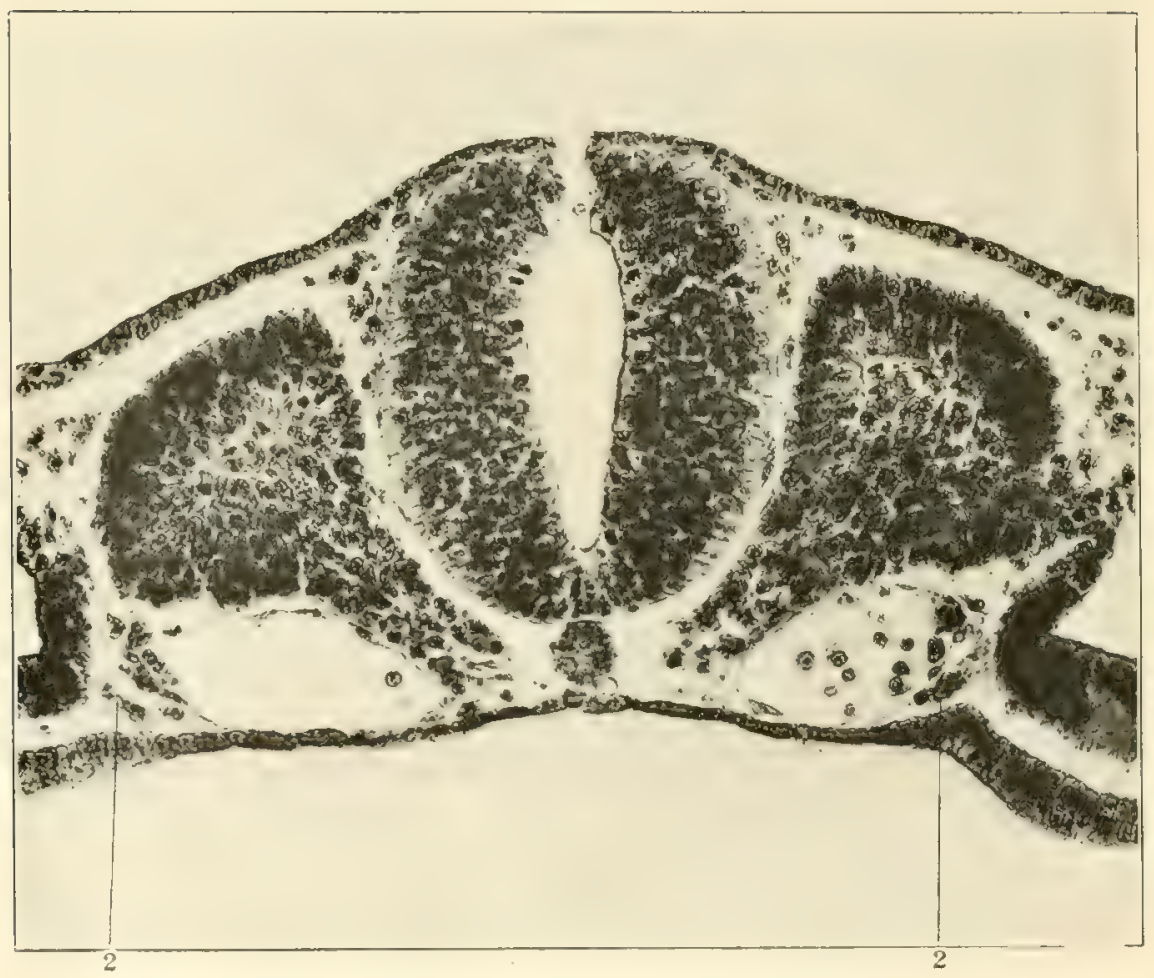

lig. 29 Serial transverse section of an enbryo of twelve somites. 2, Cells derivel from visceral mesoderm in process of accetion to the aorta. 


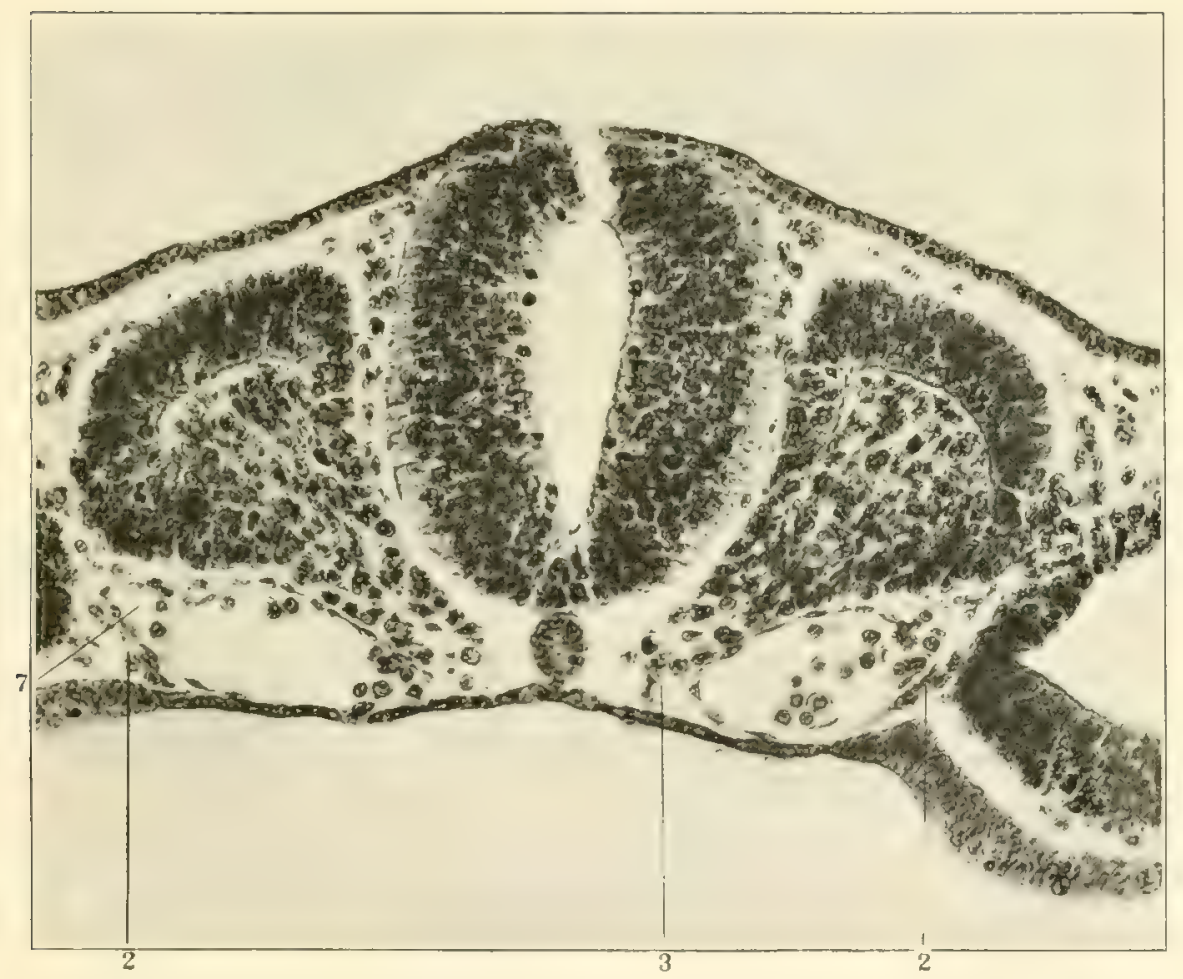

Firg. 30 Serial transverse section of an embryo of twelve somites. 2, Cells Herived from viseeral mesoderm in process of aceretion to the arota; 3, cells of selerotome in syneytial continuity with cn lotheliun; $\%$, angiocyst added to arotit; a remmant of septum is still visible. 


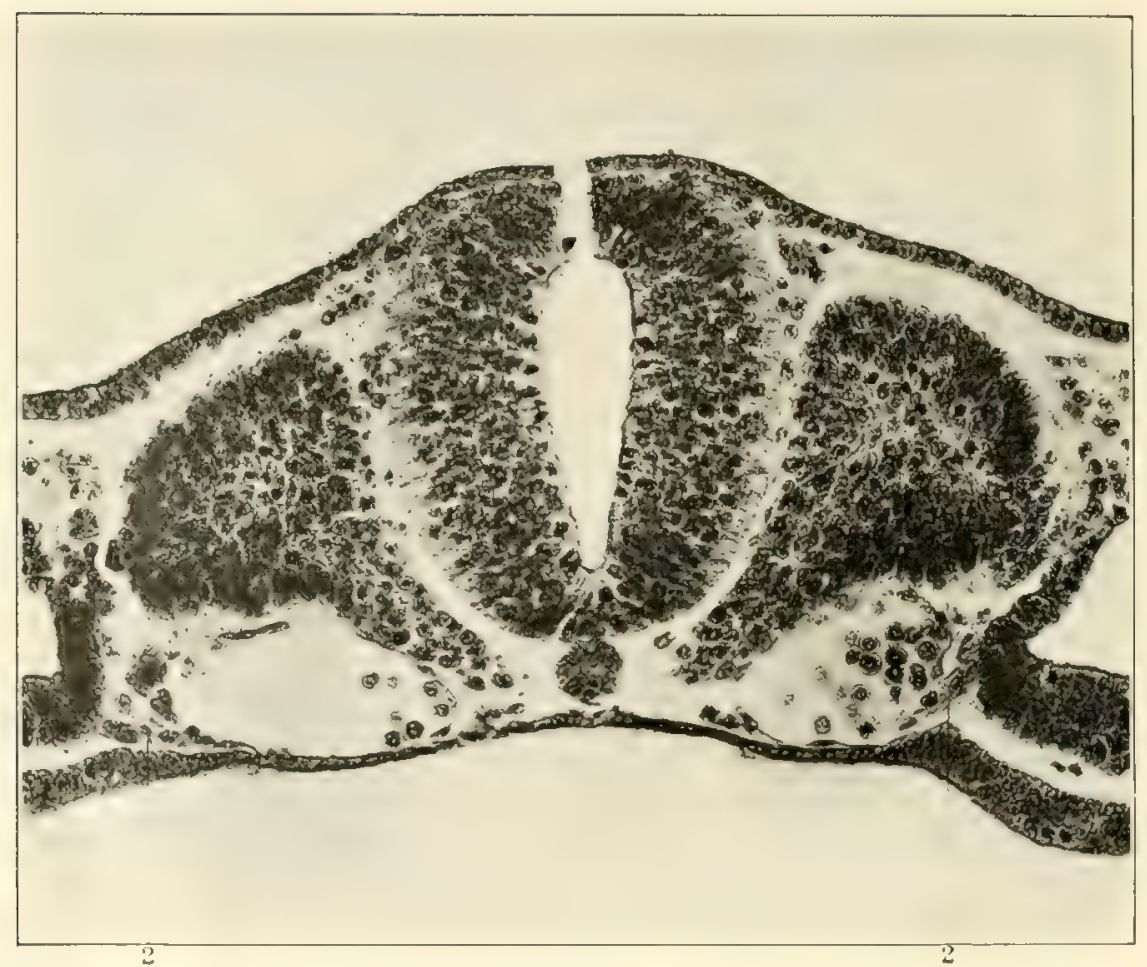

lig. 31 Serial transverse section of an embryo of twelve somites. 2. Cells derived from viscerial mesoderm in process of accretion to tort: 


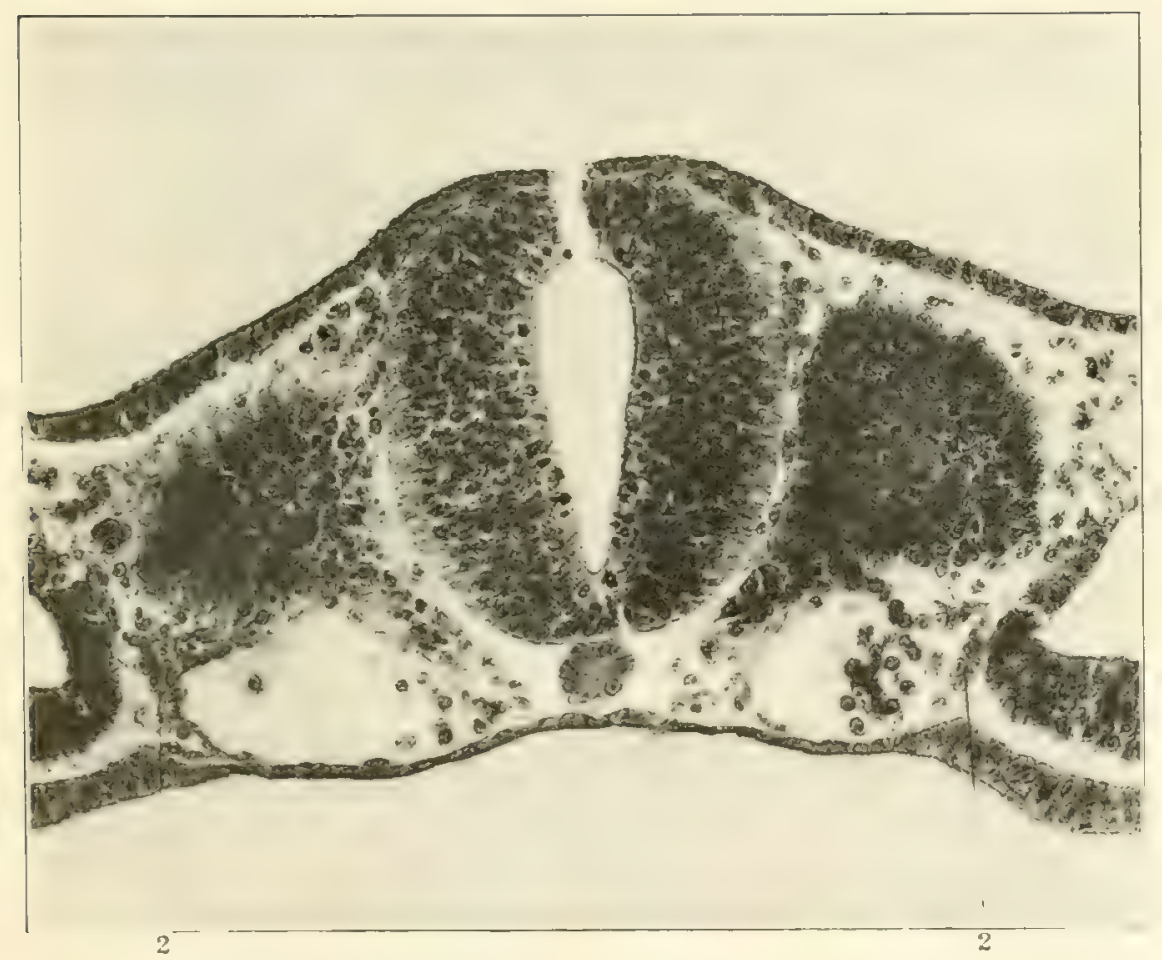

Fig. 32 Serial transverse section of an embryo of twelve sonites. 2, Cells derived from visceral mesodern in process of aceretion to worta. 


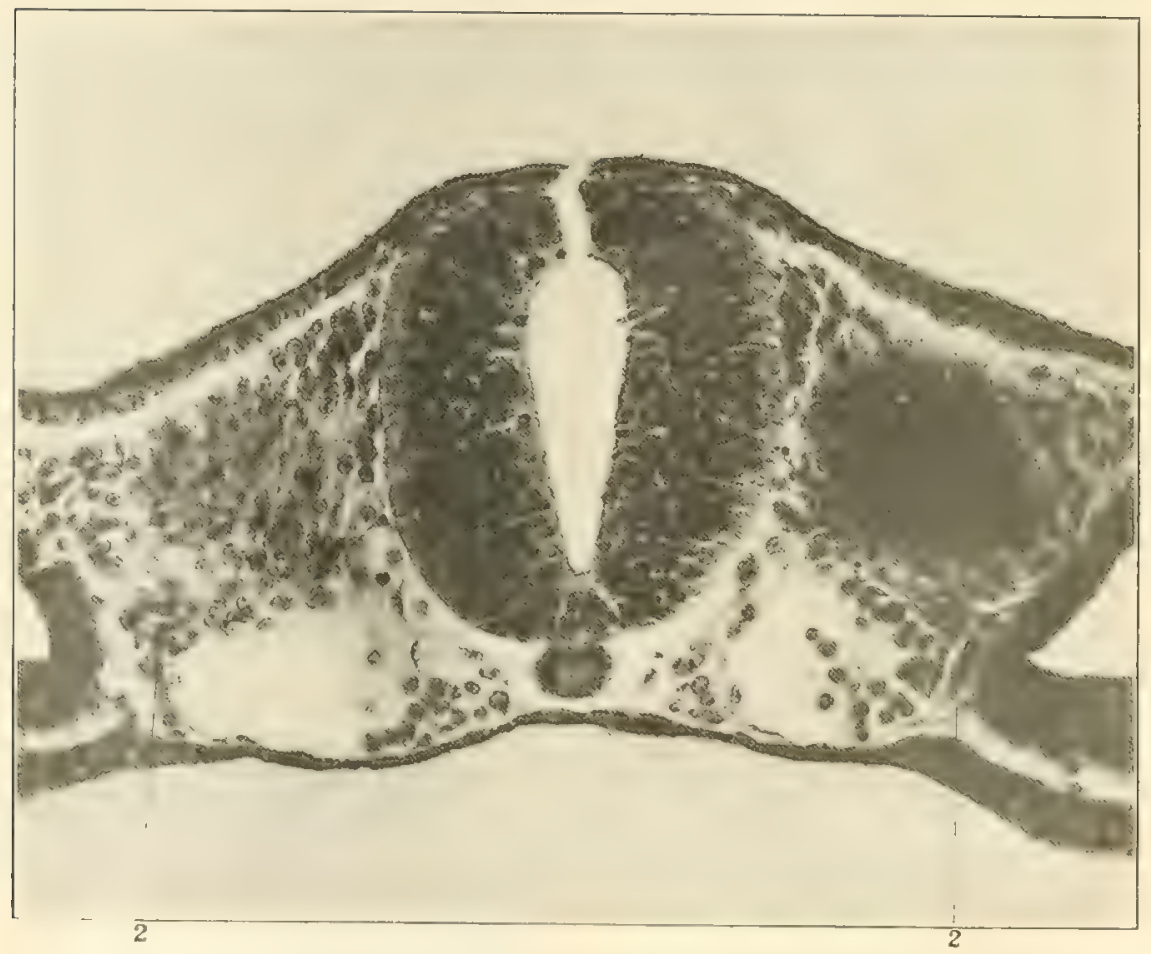

Fin. 33 herial trinsverse section of an cmbryo of twelve somites. 2, Cells derived from visceral unesodern in process of aceretion to aorta. 


QL Schulte, Hermann von

835 Wechlinger

S35 Early stages of

vasculogenesis in the cat

\section{Biomed}

\section{PLEASE DO NOT REMOVE}

CARDS OR SLIPS FROM THIS POCKET

UNIVERSITY OF TORONTO LIBRARY 
Sh-

(5) 